Prepared in cooperation with the New Jersey Department of Environmental Protection

\title{
Simulated Effects of Groundwater Withdrawals From Aquifers in Ocean County and Vicinity, New Jersey
}
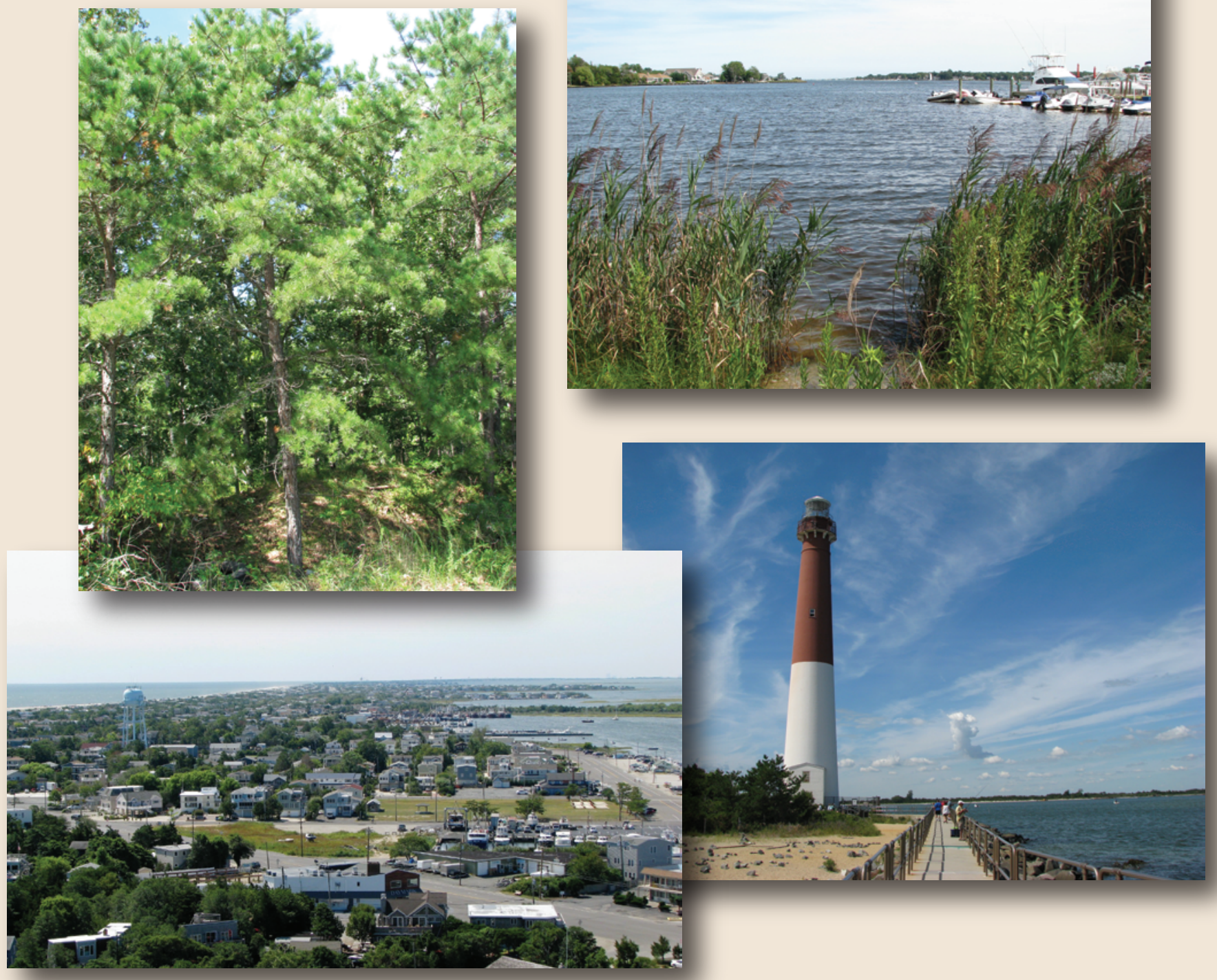

Scientific Investigations Report 2016-5035 


\section{Cover:}

Upper left: Vegetation native to the New Jersey Pinelands, Manchester Township. (Photo by Stephen Cauller, U.S. Geological Survey)

Lower left: View of Long Beach Island looking south from Barnegat Light Lighthouse. Notable landmarks include the Atlantic Ocean at far left, Barnegat Light Borough water tower at near left, and Barnegat Bay at right. (Photo by Stephen Cauller, U.S. Geological Survey)

Upper right: The southern shore of Toms River, looking to the east. (Photo by Stephen Cauller, U.S. Geological Survey)

Lower right: Barnegat Light Lighthouse overlooking Barnegat Inlet. (Photo by Stephen Cauller, U.S. Geological Survey) 


\section{Simulated Effects of Groundwater Withdrawals From Aquifers in Ocean County and Vicinity, New Jersey}

By Stephen J. Cauller, Lois M. Voronin, and Mary M. Chepiga

Prepared in cooperation with the

New Jersey Department of Environmental Protection

Scientific Investigations Report 2016-5035 


\title{
U.S. Department of the Interior SALLY JEWELL, Secretary
}

\section{U.S. Geological Survey Suzette M. Kimball, Director}

\author{
U.S. Geological Survey, Reston, Virginia: 2016
}

For more information on the USGS - the Federal source for science about the Earth, its natural and living resources, natural hazards, and the environment—visit http://www.usgs.gov or call 1-888-ASK-USGS.

For an overview of USGS information products, including maps, imagery, and publications, visit http://store.usgs.gov.

Any use of trade, firm, or product names is for descriptive purposes only and does not imply endorsement by the U.S. Government.

Although this information product, for the most part, is in the public domain, it also may contain copyrighted materials as noted in the text. Permission to reproduce copyrighted items must be secured from the copyright owner.

Suggested citation:

Cauller, S.J., Voronin, L.M., and Chepiga, M.M., 2016, Simulated effects of groundwater withdrawals from aquifers in Ocean County and vicinity, New Jersey: U.S. Geological Survey Scientific Investigations Report 2016-5035, 77 p., http://dx.doi.org/10.3133/sir20165035.

ISSN 2328-0328 (online) 


\section{Acknowledgments}

Lloyd G. Mullikin of the New Jersey Geological and Water Survey provided hydrogeologicframework data and interpretations in support of this project. The New Jersey Department of Environmental Protection, Bureau of Water Supply, provided the well-permit, water-allocationpermit, and water-use data used in the study. The New Jersey Department of Environmental Protection provided funding for the development of the groundwater flow model.

The authors gratefully acknowledge the assistance of U.S. Geological Survey employees Nicholas Smith in the collection of groundwater-level data, and Jennifer Shourds and John Nawyn in the tabulation of water-use data for this project. Jean Brown performed base-flow separations, and Debra Buxton estimated monthly recharge. Daryll Pope assisted in the development of input files for the Recharge package, and Flow and Head Boundary package of the groundwater-flow model. Leon Kauffman provided a method to graphically present output from particle tracking analysis. Erzsebet Potyo volunteered her time in the preparation of several draft figures. Critical review of the draft report by Cheryl Dieter and Glen Carleton improved the overall content, while reviews by Ruth Larkins and Marc Zimmerman improved the clarity of the text. Gregory Simpson created the layout of report text and figures, and the digital archive of the groundwater-flow model was prepared by Martha Watt. 



\section{Contents}

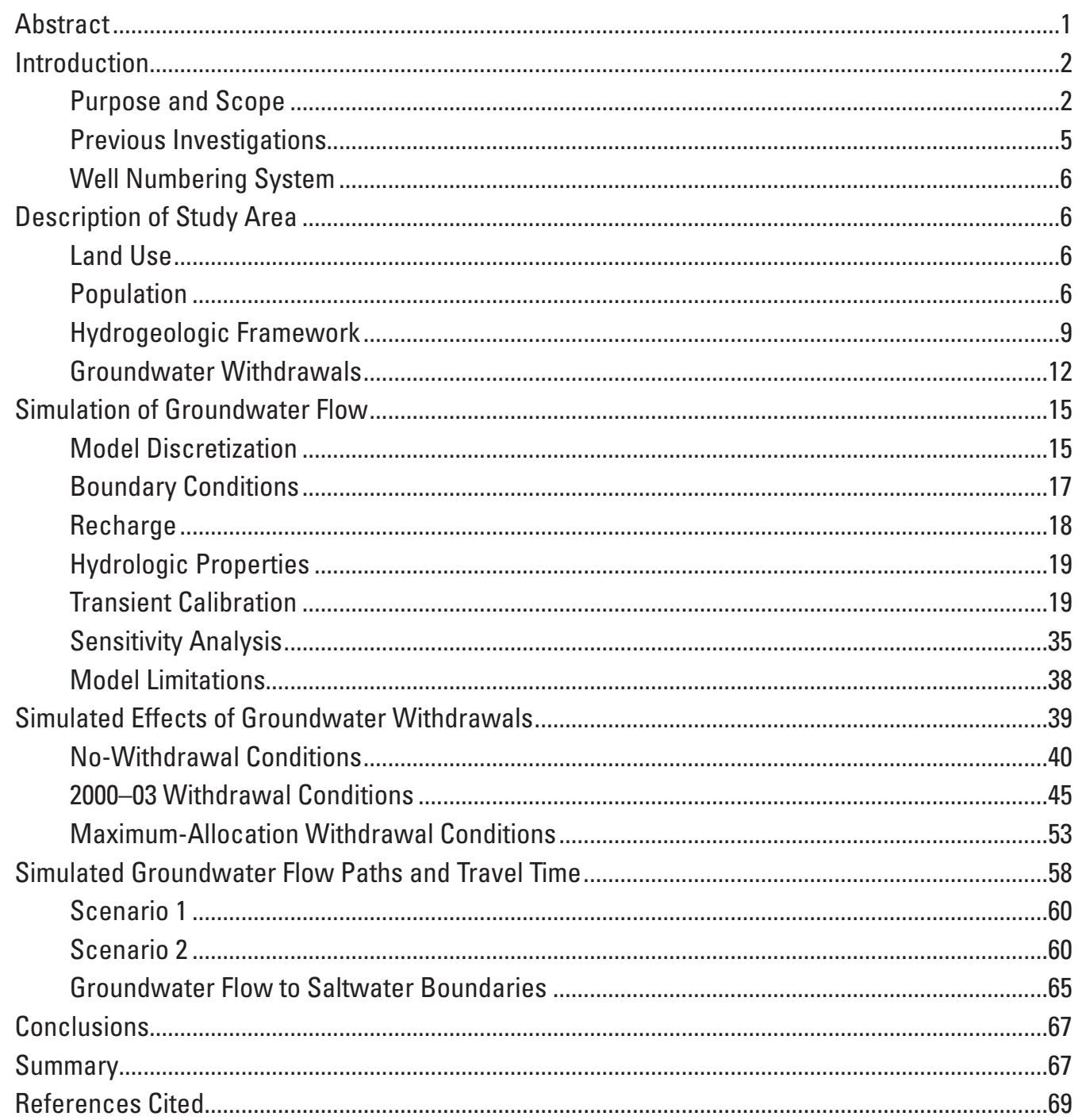




\section{Figures}

1. Map showing location of study area and major roads in New Jersey .............................

2. Map showing location of townships, Ocean County study area, New Jersey ..................4

3. Diagrammatic section through the Kirkwood-Cohansey aquifer system, Rio Grande water-bearing zone, Atlantic City 800-foot sand, Piney Point, and Vincentown aquifers, illustrating the relation between model layers and aquifers, 0 cean County study area, New Jersey...

4. Map showing location of surface-water basins, Ocean County study area, New Jersey.

5. Maps showing land use in the Ocean County study area, New Jersey, in $A, 1973$ and $B, 2007$.

6. Maps showing extent of hydrogeologic units: $A$, unconfined Kirkwood-Cohansey aquifer system and Vincentown aquifer; $B$, confined Rio Grande water-bearing zone and semi-confined zone; $C$, confined Atlantic City 800 -foot sand and semi-confined zone; $D$, confined Piney Point aquifer, upper sand; and $E$, confined Piney Point aquifer, lower sand and Vincentown aquifer, Ocean County study area, New Jersey ...10

7. Map showing location of groundwater-withdrawal wells screened in the Kirkwood-Cohansey aquifer system, Rio Grande water-bearing zone, Atlantic City 800 -foot sand, Piney Point aquifer, and Vincentown aquifer, Ocean County study area, New Jersey, with withdrawal records from 2000 to 2003

8. Graphs showing reported annual groundwater withdrawals by: $A$, water allocation permit series and $B$, aquifer, Ocean County study area, New Jersey, from 2000 to 2003

9. Map showing variably spaced model grid, lateral boundaries, and representation of water bodies in the Ocean County study area, New Jersey

10. Graph showing monthly and annual simulated recharge, 2000 to 2003, Ocean County study area, New Jersey

11. Maps showing simulated 0 ctober 2003 and composite measured water tables of the $A$, Kirkwood-Cohansey aquifer system; and simulated October 2003 and measured potentiometric surfaces of the, $B$, Rio Grande water-bearing zone; $C$, Atlantic City 800-foot sand, upper sand; $D$, Atlantic City 800 -foot sand, lower sand; and $E$, Piney Point aquifer, upper sand, 0 cean County study area, New Jersey ..

12. Map showing location of selected hydrograph wells with periodic water-level measurements, Ocean County study area, New Jersey.

13. Graphs showing hydrographs of simulated and measured water levels at selected wells screened in: $A$ to $F$, the Kirkwood Cohansey aquifer system; $G$ to $H$, Rio Grande water-bearing zone; I to $K$, Atlantic City 800 -foot sand; and; $L$ to $N$, Piney Point aquifer, Ocean County study area, New Jersey, 2000 to 2003.

14. Map showing location of selected streamflow-gaging stations in the Ocean County study area, New Jersey

15. Graphs showing estimated monthly and simulated monthly base flow from January 2000 to December 2003 at streamflow-gaging stations: $A$, North Branch Metedeconk River near Lakewood (01408120); B, South Branch Metedeconk River near Lakewood (01408150); $C$, Toms River near Toms River (01408500); D, Wrangel Brook at Mule Road near Toms River (01408592); E, Cedar Creek at Lanoka Harbor (01409000); F, North Branch Forked River near Forked River (01409050); G, Oyster Creek near Waretown (01409100); H, Mill Creek near Manahawkin (01409150); I, Cedar Run near Manahawkin (01409250); J, Westecunk Creek at Stafford Forge (01409280); K, East Branch Bass River near New Gretna (01410150); and L, Oswego River at Harrisville (01410000), New Jersey 
16. Graphs showing hydraulic property zones used during the calibration process for estimating hydraulic conductivity, specific storage, and specific yield, Ocean County study area, New Jersey.....

17. Graph showing composite scaled sensitivity values, Ocean County study area, New Jersey.

18. Graphs showing groundwater-flow budgets during selected stress periods under no-withdrawal conditions for: $A$, the Kirkwood-Cohansey aquifer system, $B$, Rio Grande water-bearing zone, $C$, Atlantic City 800 -foot sand, and D, Piney Point aquifer, upper sand, 0 cean County study area

19. Graphs showing simulated water levels in selected observation wells screened in: the unconfined Kirkwood-Cohansey aquifer system, wells $A, 29-141, B$, 29-1060, C, 29-513, D, 29-17; the confined Rio Grande water-bearing zone, wells $E$, 29-775, F, 29-1621; Atlantic City 800-foot sand, wells G, 29-9, H, 29-457, I, 29-936, J, 29-464, and $K, 29-814$; and; Piney Point aquifer, wells $L, 29-2, M, 29-425, N$, 29-582, and $0,29-1210$, during no-withdrawal, 2000-03 withdrawal, and maximumallocation withdrawal conditions, Ocean County study area, New Jersey.

20. Graphs showing groundwater-flow budgets during selected stress periods under 2000-03 withdrawal conditions for the $A$, Kirkwood-Cohansey aquifer system, $B$, Rio Grande water-bearing zone, $C$, Atlantic City 800 -foot sand, and $D$, Piney Point aquifer, upper sand, Ocean County study area, New Jersey.

21. Maps showing simulated potentiometric surfaces of the Rio Grande water-bearing zone during: $A$, no-withdrawal, stress period 73 (August 2002); $B$, 2000-03 withdrawal, stress period 73 (August 2002); $C$, maximum-allocation withdrawal, stress period 73 (August 2002); D, no-withdrawal, stress period 80 (March 2003); E, 2000-03 withdrawal, stress period 80 (March 2003); and; $F$, maximum-allocation withdrawal conditions, stress period 80 (March 2003), Ocean County study area, New Jersey .

22. Maps showing simulated drawdown of potentiometric surfaces of the: $A$, Rio Grande water-bearing zone; $B$, Atlantic City 800 -foot sand, upper sand; $C$, Atlantic City 800 -foot sand, lower sand; and $D$, Piney Point aquifer, upper sand from no-withdrawal to 2000-03 withdrawal conditions, stress period 73 (August 2002), Ocean County study area, New Jersey ...

23. Maps showing simulated potentiometric surfaces of the Atlantic City 800-foot sand, upper sand during: $A$, no-withdrawal, stress period 73 (August 2002); $B$, 2000-03 withdrawal, stress period 73 (August 2002); $C$, maximum-allocation withdrawal, stress period 73 (August 2002); $D$, no-withdrawal, stress period 80 (March 2003); E, 2000-03 withdrawal, stress period 80 (March 2003); and $F$, maximum-allocation withdrawal conditions, stress period 80 (March 2003), Ocean County study area, New Jersey.

24. Maps showing simulated potentiometric surfaces of the Piney Point aquifer, upper sand during: $A$, no-withdrawal, stress period 73 (August 2002); B, 2000-03 withdrawal, stress period 73 (August 2002); $C$, maximum-allocation withdrawal, stress period 73 (August 2002); D, no-withdrawal, stress period 80 (March 2003); $E$, 2000-03 withdrawal, stress period 80 (March 2003); and $F$, maximum-allocation withdrawal conditions, stress period 80 (March 2003), 0cean County study area, New Jersey.

25. Graphs showing groundwater-flow budgets during selected stress periods under maximum-allocation withdrawal conditions for the: $A$, Kirkwood-Cohansey aquifer system; $B$, Rio Grande water-bearing zone; $C$, Atlantic City 800-foot sand; and $D$, Piney Point aquifer, upper sand, 0 cean County study area, New Jersey...... 
26. Graphs showing monthly base flow during no-withdrawal, 2000-03 withdrawal, and maximum-allocation withdrawal conditions at streamflow-gaging stations: A, North Branch Metedeconk River near Lakewood, N.J. (01408120); B, South Branch Metedeconk River near Lakewood, N.J. (01408150); C, Toms River near Toms River, N.J. (01408500); D, Wrangel Brook at Mule Road near Toms River, N.J. (01408592); E, Cedar Creek at Lanoka Harbor, N.J. (01409000); F, North Branch Forked River near Forked River, N.J. (01409050); G, Oyster Creek near Waretown, N.J. (01409100); H, Mill Creek near Manahawkin, N.J. (01409150); I, Cedar Run near Manahawkin, N.J. (01409250); J, Westecunk Creek at Stafford Forge, N.J. (01409280); K, East Branch Bass River near New Gretna, N.J. (01410150); and L, Oswego River at Harrisville, N.J. (01410000), Ocean County study area, New Jersey

27. Maps showing simulated drawdown of potentiometric surfaces of the: $A$, Rio Grande water-bearing zone; $B$, Atlantic City 800 -foot sand, upper sand; $C$, Atlantic City 800-foot sand, lower sand; and $D$, Piney Point aquifer, upper sand from no-withdrawal to maximum-allocation withdrawal conditions, stress period 73 (August 2002), Ocean County study area, New Jersey.....

28. Map showing locations of selected wells screened in the Kirkwood-Cohansey aquifer system proximal to the coastline and production wells screened in the Rio Grande water-bearing zone or in the Atlantic City 800 -foot sand, used in particle-tracking analysis, Ocean County study area, New Jersey......

29. Map showing flow paths from point of recharge to point of discharge and travel time of particles that discharge to near-shore wells screened in the unconfined Kirkwood-Cohansey aquifer system, average 2000-03 withdrawal conditions, Ocean County study area, New Jersey.

30. Map showing flow paths from point of recharge to point of discharge and travel time of particles that discharge to wells screened in the Rio Grande water-bearing zone or the Atlantic City 800-foot sand, average 2000-03 withdrawal conditions, Ocean County study area, New Jersey

31. Map showing flow paths from point of recharge to point of discharge and travel time of particles that discharge to near-shore wells screened in the unconfined Kirkwood-Cohansey aquifer system, average maximum-allocation withdrawal conditions, Ocean County study area, New Jersey.

32. Map showing flow paths from point of recharge to point of discharge and travel time of particles that discharge to wells screened in the Rio Grande water-bearing zone or the Atlantic City 800-foot sand, average maximum-allocation withdrawal conditions, Ocean County study area, New Jersey

33. Maps showing groundwater flow into, or out of, constant head cells in the Barnegat Bay-Little Egg Harbor, Great Bay, Atlantic Ocean, and coastal wetlands for $A, 2000-03$ withdrawal conditions, and $B$, maximum-allocation withdrawal conditions, Ocean County study area, New Jersey. 


\section{Tables}

1. Land use in the Ocean County study area, New Jersey ..................................................

2. Stratigraphic and hydrogeologic units, Ocean County area, New Jersey .......................11

3. New Jersey Department of Environmental Protection water allocation permit series

4. Groundwater model layers and corresponding hydrogeologic units in the Ocean County study area, New Jersey....

5. Published hydraulic properties of aquifers and confining units in the Coastal Plain of New Jersey.

6. Hydraulic properties used in groundwater-flow model simulations for the Ocean County study area, New Jersey.

7. Average differences between simulated water levels and water levels measured from January 2000 to December 2003 in selected wells, Ocean County study area, New Jersey.

8. Simulated and estimated mean monthly base flow at selected streamflow-gaging stations, Ocean County study area, New Jersey, January 2000 to December 2003

9. Time period, groundwater-withdrawal rate, groundwater discharge to streams, and recharge rate simulated in the groundwater-flow model, 0 cean County study area, New Jersey

10. Calibrated model parameter values and composite scaled sensitivities, 0cean County study area, New Jersey

11. Simulated base-flow reductions at selected streamflow-gaging stations from no-withdrawal to 2000-03 withdrawal and maximum-allocation withdrawal conditions, Ocean County study area, New Jersey.

12. Simulated base flow to streams that flow into the Barnegat Bay-Little Egg Harbor estuary, stress periods 64 (November 2001), 73 (August 2002), 77 (December 2002), 80 (March 2003), and 87 (October 2003), Ocean County study area, New Jersey 


\section{Conversion Factors and Datum}

\begin{tabular}{|c|c|c|}
\hline Multiply & By & To obtain \\
\hline \multicolumn{3}{|c|}{ Length } \\
\hline inch (in.) & 2.54 & centimeter $(\mathrm{cm})$ \\
\hline foot $(\mathrm{ft})$ & 0.3048 & meter $(\mathrm{m})$ \\
\hline mile (mi) & 1.609 & kilometer $(\mathrm{km})$ \\
\hline \multicolumn{3}{|c|}{ Area } \\
\hline square mile $\left(\mathrm{mi}^{2}\right)$ & 2.590 & square kilometer $\left(\mathrm{km}^{2}\right)$ \\
\hline acre & 0.4047 & hectare (ha) \\
\hline \multicolumn{3}{|c|}{ Volume } \\
\hline gallon (gal) & 3.785 & liter (L) \\
\hline gallon (gal) & 0.003785 & cubic meter $\left(\mathrm{m}^{3}\right)$ \\
\hline million gallons (Mgal) & 3,785 & cubic meter $\left(\mathrm{m}^{3}\right)$ \\
\hline \multicolumn{3}{|c|}{ Flow rate } \\
\hline cubic foot per second $\left(\mathrm{ft}^{3} / \mathrm{s}\right)$ & 0.02832 & cubic meter per second $\left(\mathrm{m}^{3} / \mathrm{s}\right)$ \\
\hline gallon per day (gal/d) & 0.003785 & cubic meter per day $\left(\mathrm{m}^{3} / \mathrm{d}\right)$ \\
\hline
\end{tabular}

Vertical coordinate information is referenced to the National Geodetic Vertical Datum of 1929 (NGVD 29).

Horizontal coordinate information is referenced to the North American Datum of 1983 (NAD 83).

Altitude, as used in this report, refers to distance above the vertical datum. Negative altitude refers to distance below the vertical datum.

\section{Abbreviations}

CSS

FHB1

GIRAS

NJDEP

NJGWS

RASA

USGS
Composite scaled sensitivities

Flow and Head Boundary Package

Geographic Information and Retrieval Analysis System

New Jersey Department of Environmental Protection

New Jersey Geological and Water Survey

Regional Aquifer System Analysis

U.S. Geological Survey 



\title{
Simulated Effects of Groundwater Withdrawals From Aquifers in Ocean County and Vicinity, New Jersey
}

\author{
By Stephen J. Cauller, Lois M. Voronin, and Mary M. Chepiga
}

\section{Abstract}

Rapid population growth since the 1930s in Ocean County and vicinity, New Jersey, has placed increasing demands upon the area's freshwater resources. To examine effects of groundwater withdrawals, a three-dimensional groundwater-flow model was developed to simulate the groundwater-flow systems of five area aquifers: the unconfined Kirkwood-Cohansey aquifer system and Vincentown aquifer, and three confined aquifers - the Rio Grande water-bearing zone, the Atlantic City 800-foot sand, and the Piney Point aquifer. The influence of withdrawals is evaluated by using transient groundwater-flow model simulations that incorporate three withdrawal schemes. These are (1) no-withdrawal conditions; (2) 2000-03 withdrawal conditions, using reported monthly withdrawals at all production wells from January 2000 through December 2003; and (3) maximum-allocation withdrawal conditions using the maximum withdrawal allowed by New Jersey Department of Environmental Protection permits at each well. Particle tracking analysis, using results from model simulations, delineated particle flow paths from production wells to the point of recharge, and estimated particle travel times.

Compared with no-withdrawal conditions, 2000-03 withdrawal conditions reduced the amount of groundwater flow out of the Kirkwood-Cohansey aquifer system into streams, increased the net flow of water into other layers, reduced net flow into or out of storage, and reduced flow from the Kirkwood-Cohansey aquifer system to constant head cells.

Freshwater discharging to the Barnegat Bay-Little Egg Harbor estuary from streams and groundwater is essential to maintaining the ecology of the bay. Examination of selected stress periods indicates that simulated base flow in streams flowing into the Barnegat Bay-Little Egg Harbor estuary is reduced by as much as 49 cubic feet per second for 2000 to 2003 withdrawal conditions when compared with no-withdrawal conditions.

In the three confined aquifers, water levels during periods of low recharge and high withdrawals, and high recharge and low withdrawals, were examined to determine seasonal effects on the confined flow systems. The simulated potentiometric surface of the Rio Grande water-bearing zone and the Atlantic City 800-foot sand during selected stress periods indicates substantial declines from no-withdrawal conditions to $2000-03$ conditions as a result of groundwater withdrawals. Cones of depression in Toms River Township, Seaside Heights and Seaside Park Boroughs, and Barnegat Light Borough developed in the potentiometric surface of the Piney Point aquifer in response to withdrawals.

Maximum-allocation withdrawals decreased flow out of the Kirkwood-Cohansey aquifer system to constant head cells, increased flow out of the aquifer system to adjacent and lower layers, and reduced groundwater discharge to streams when compared with 2000-03 withdrawal conditions. Increases in withdrawals from the Rio Grande water-bearing zone, the Atlantic City 800-foot sand, and the Piney Point aquifer result in an increase in simulated net groundwater flow into these aquifers. Base-flow reduction from 2000-03 conditions to maximum-allocation conditions of 25 to 29 cubic feet per second in all streams draining to the Barnegat Bay-Little Egg Harbor also is indicated. Potentiometric surfaces of the Rio Grande water-bearing zone, Atlantic City 800-foot sand, and the Piney Point aquifer during two stress periods of simulated maximum-allocation withdrawal conditions indicated the expansion of several cones of depression developed during 2000-03 withdrawals.

Simulation of average 2000-03 withdrawal conditions indicated the extent to which the groundwater-flow system is susceptible to potential saltwater intrusion into nearshore wells. Travel time from recharge to discharge location ranged from 11 to approximately 50,700 years in near-shore Kirkwood-Cohansey aquifer system wells. Those in Seaside Heights Borough, in Island Beach State Park (Berkeley Township), and in Ship Bottom Borough have particle travel times from 140 to 12,000 years and flow paths that originated under Barnegat Bay or the Atlantic Ocean from the simulation of average maximum-allocation withdrawal conditions.

Travel time along flow paths to wells screened in the Rio Grande water-bearing zone and the Atlantic City 800-foot sand from recharge to discharge point ranged from nearly 530 years to greater than 3.73 million years from the simulation of average 2000-03 withdrawal conditions. Particle tracking indicated that most wells screened in these aquifers derived a large part of their recharge from the Oswego River Basin, with a 
small portion of flow originating either beneath Barnegat Bay or to the east beneath the Atlantic Ocean. Travel time along flow paths that start beneath either Barnegat Bay or the Atlantic Ocean ranged from 2,300 to approximately 134,000 years from the simulation of average maximum-allocation withdrawal conditions.

\section{Introduction}

The southernmost part of Monmouth County and the northern half of Ocean County, New Jersey, have experienced rapid population growth and subsequent residential and commercial land development during the period of 1930 to 2000, particularly in areas close to the shoreline; Ocean County experienced the largest percent change in population $(1,445$ percent) of all the counties in the State (Ocean County Department of Planning, 2006). The conversion of undeveloped land to residential use was followed by the development of a burgeoning infrastructure to support the needs of the community, including the development of transportation corridors, commercial strip malls, shopping centers, pockets of industrial land, and various commercial endeavors. Groundwater withdrawals from the Kirkwood-Cohansey aquifer system, the Rio Grande water-bearing zone, the Atlantic City 800-foot sand, and the Piney Point and Vincentown aquifers in this area increased from an estimated 606 million gallons in 1930 (Zapecza and others, 1987) to approximately 14 billion gallons in 2003 to serve the needs of the growing population.

Conversion of undeveloped land to residential use has accelerated in the southern half of Ocean County, especially along the Garden State Parkway corridor and east to the coast (fig. 1). From 1997 to 2007, in the southern half of Ocean County, Barnegat, Ocean, and Stafford Townships and Little Egg Harbor (fig. 2) experienced some of the highest rates of population growth in the county, ranging from 34 to nearly 54 percent (Ocean County Department of Planning, 2009). As the population grew, demands placed on the available supply of freshwater also increased. The barrier island beach communities experienced a large seasonal population increase and high water demand during the summer months. Several communities in northern Ocean County increased their groundwater withdrawals from the confined Piney Point aquifer, and several southern communities increased their withdrawals from confined parts of the Kirkwood-Cohansey aquifer system, the Rio Grande water-bearing zone, and the Atlantic City 800-foot sand (fig. 3).

In the study area, streamflow is the main source of freshwater flow into the Barnegat Bay-Little Egg Harbor estuary. Direct precipitation and subsurface groundwater flow are secondary sources of freshwater flow to the estuary. Groundwater flow to streams, or base flow, is a major component of freshwater flow in streams that drain the New Jersey Coastal Plain. Withdrawals of groundwater in the study area reduce the quantity of both groundwater discharge to streams that flow into the bay and groundwater discharge directly into the bay. This reduction has potential implications for the salinity of the bay water, the flora and fauna supported in the bay ecosystem, and the overall health of the estuary.

Water-supply wells near the shore or on the barrier islands tend to be susceptible to saltwater intrusion because of their proximity to salty water either in the Barnegat Bay-Little Egg Harbor or the Atlantic Ocean. Production wells screened in the confined Rio Grande water-bearing zone and Atlantic City 800 -foot sand may be susceptible to sources of saltwater either downdip in the aquifer or updip where confinement ends.

\section{Purpose and Scope}

The U.S. Geological Survey (USGS), in cooperation with the New Jersey Department of Environmental Protection (NJDEP), studied the effects of year 2000-03 and maximumallocation groundwater withdrawals from the KirkwoodCohansey aquifer system, the Rio Grande water-bearing zone, the Atlantic City 800-foot sand, and the Piney Point and Vincentown aquifers on the freshwater supply in Ocean County and vicinity (referred to as the Ocean County study area). As of 2003, groundwater withdrawals had created cones of depression in the potentiometric surfaces of the Rio Grande water-bearing zone, the Atlantic City 800-foot sand, and the Piney Point aquifer in parts of the study area. The purpose of this study is to assess the effects of groundwater withdrawals on groundwater levels in the confined portions of the aquifer system, and groundwater flow to streams and to the Barnegat Bay-Little Egg Harbor estuary, using a groundwater model to simulate various pumping scenarios.

This report documents the results of groundwater-flow simulations for aquifers in the Atlantic coastal basins of central New Jersey. The report focuses primarily on the basins in Ocean County that drain into Barnegat Bay and Little Egg Harbor. Aquifers included in this study are the unconfined, surficial Kirkwood-Cohansey aquifer system; the deeper, confined parts of the Kirkwood Formation, which includes the Rio Grande water-bearing zone and the Atlantic City 800-foot sand; the Piney Point aquifer; and the Vincentown aquifer in the northwestern part of the study area. Groundwater flow through the subject aquifers is simulated. Groundwater flow to streams and ultimately to the Barnegat Bay-Little Egg Harbor estuary is estimated. This report presents the results of simulations that represent no groundwater withdrawals, 2000-03 groundwater withdrawals, and maximum-allocation groundwater withdrawals. Particle-tracking scenarios are simulated to determine flow paths and travel times to near-shore wells screened in the unconfined Kirkwood-Cohansey aquifer system, the Rio Grande water-bearing zone, and the Atlantic City 800 -foot sand. Sources of water to wells in both unconfined and confined aquifers and travel times based on particle-tracking analysis are used to assess the susceptibility of selected wells to saltwater intrusion from bay or ocean water. 


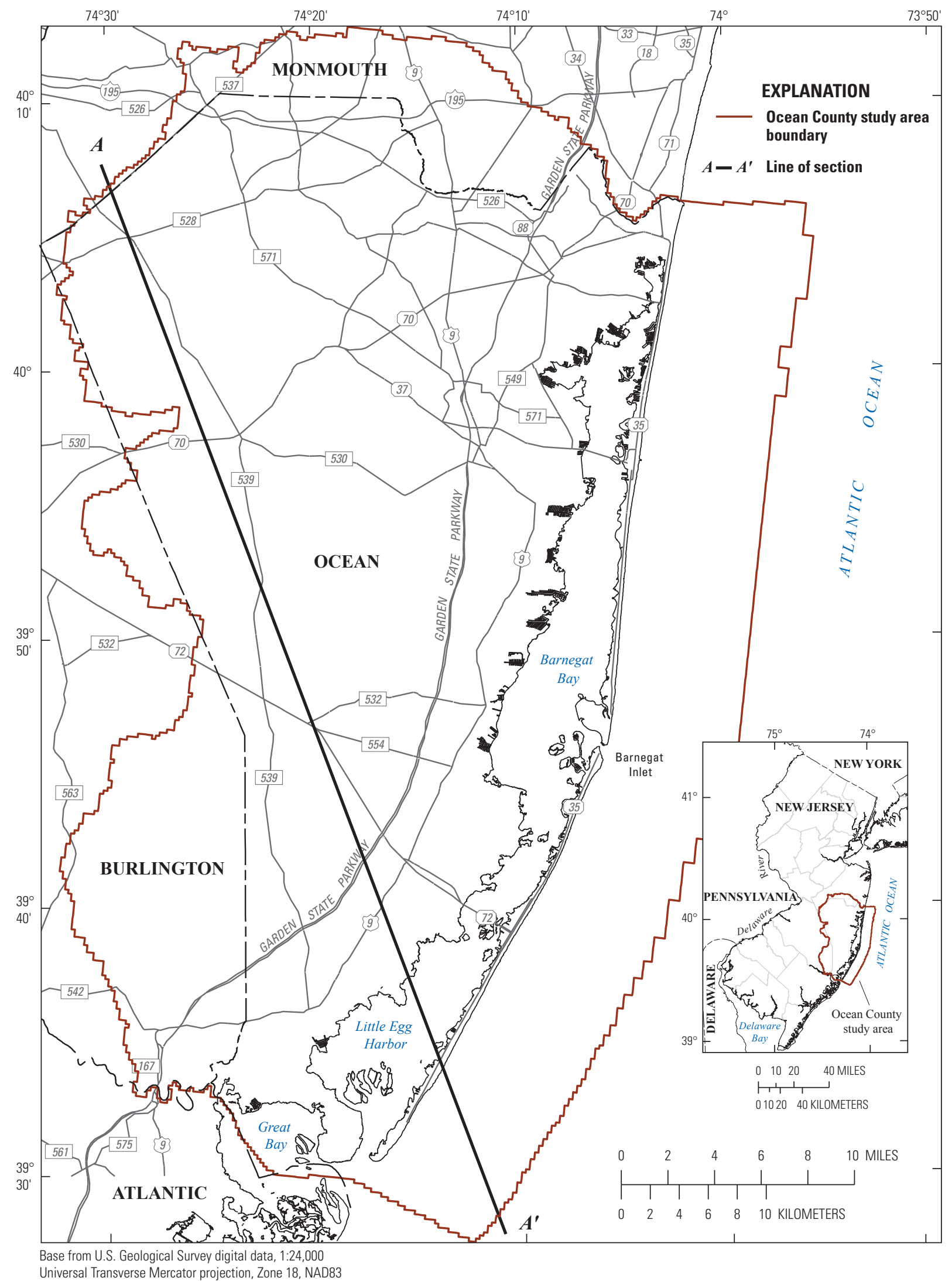

Figure 1. Location of study area and major roads in New Jersey. 


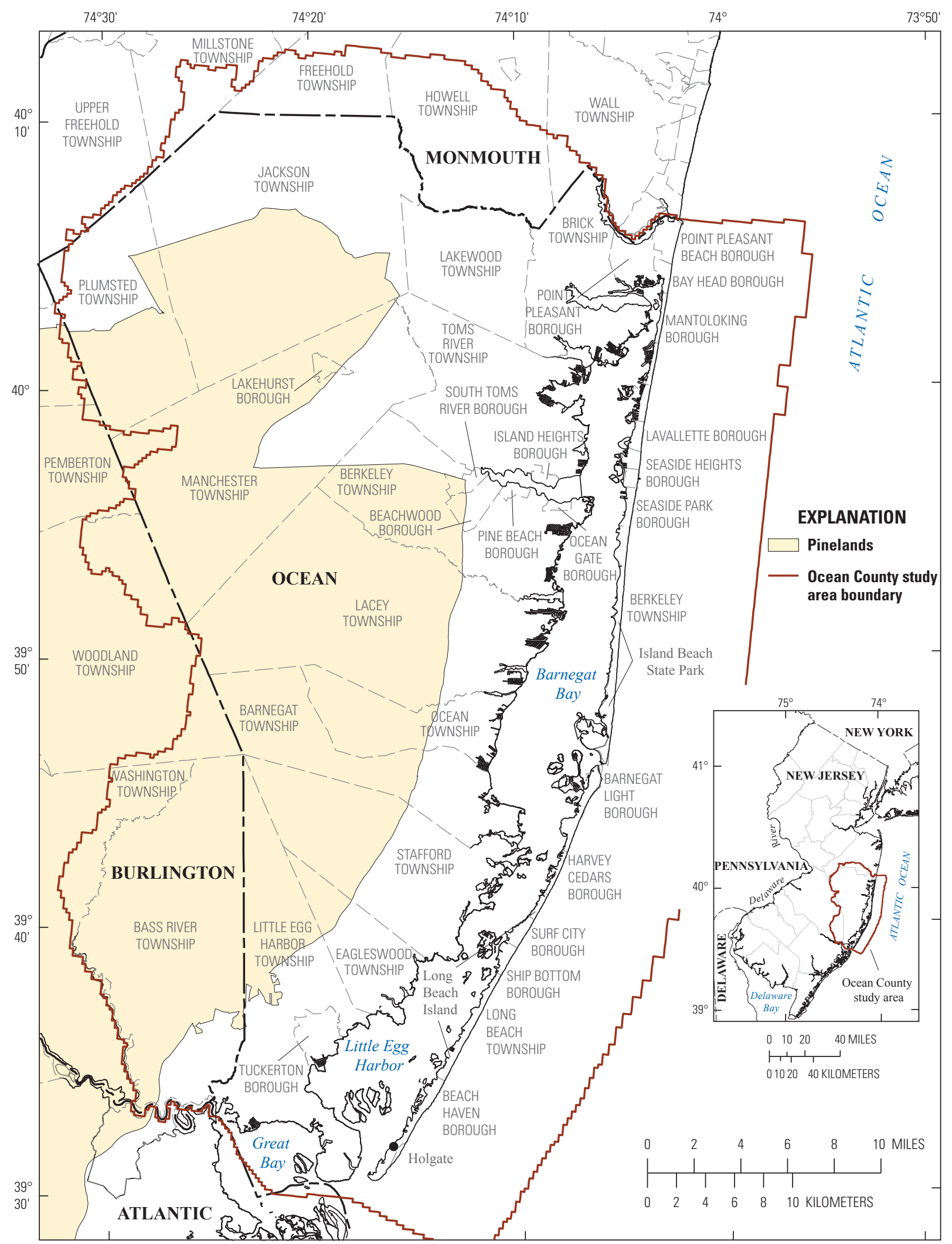

Base from U.S. Geological Survey digital data, 1:24,000

Universal Transverse Mercator projection, Zone 18, NAD83

Figure 2. Location of townships, Ocean County study area, New Jersey. 


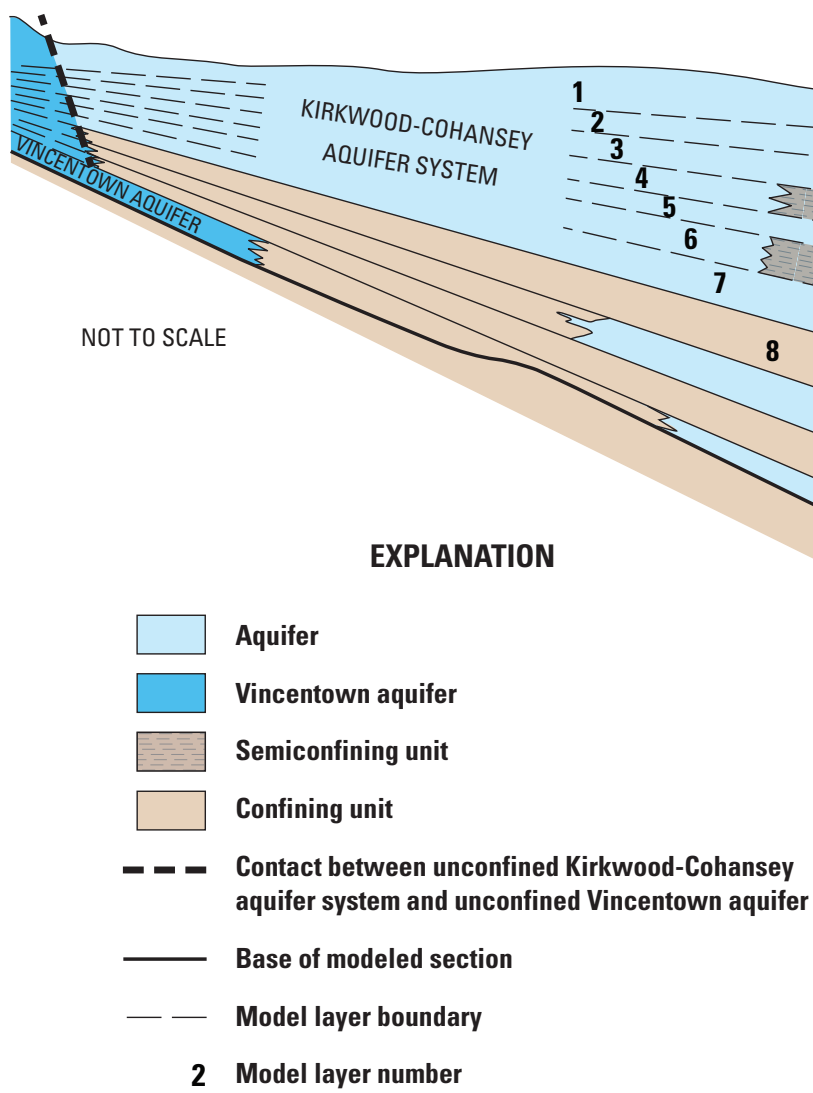

Figure 3. Diagrammatic section through the Kirkwood-Cohansey aquifer system, Rio Grande water-bearing zone, Atlantic City 800-foot sand, Piney Point, and Vincentown aquifers, illustrating the relation between model layers and aquifers, Ocean County study area, New Jersey. Line of section is shown in figure 1.

\section{Previous Investigations}

Isphording (1970) characterized the stratigraphy of the Kirkwood Formation. Sugarman (2001) presented the geology and stratigraphic relations of the Kirkwood and Cohansey Formations. Nemickas and Carswell (1976) described the stratigraphic relation and geology of the lower Kirkwood Formation and the Piney Point aquifer. Owens and others (1998) described and mapped the bedrock geology of central and southern New Jersey. Newell and others (2000) presented detailed descriptions and mapping of the surficial sedimentary deposits of central and southern New Jersey.

Zapecza (1989) presented a comprehensive study of the hydrogeologic framework of the New Jersey Coastal Plain and mapped the subsurface extent and stratigraphic relations of all the aquifers and confining units. A series of maps of the potentiometric surface of the confined aquifers in the New Jersey Coastal Plain, produced at 5-year increments, illustrated changes in the hydrologic system during 1988, 1993, 1998, and 2003 (Rosman and others, 1995; Lacombe and Rosman,
1997; Lacombe and Rosman, 2001; dePaul and others, 2009) The geology and groundwater resources of Ocean County were documented by Anderson and Appel (1969). The hydrology of the unconfined Kirkwood-Cohansey aquifer system in the Metedeconk River and Toms River Basins in the northern part of Ocean County was described by Watt and others (1994), and the hydrology of the Atlantic coastal basins and Mullica River Basin in the southern part of the Ocean County study area was described by Gordon (2004) and Johnson and Watt (1996), respectively. The geology and hydrology of the Mullica River Basin were documented by Rhodehamal (1973).

Several groundwater-flow models were developed and documented for the coastal plain aquifers in New Jersey or parts of specific aquifers that extend into Ocean County. The Regional Aquifer System Analysis (RASA) model encompassed all the aquifers and confining units of the New Jersey Coastal Plain, which includes the Ocean County study area (Martin, 1998; Voronin, 2004). McAuley and others (2001) developed a groundwater-flow model of the Atlantic City 800 -foot sand which extends approximately from the middle 
of Ocean County south through Cape May County. Nicholson and Watt (1997) developed a groundwater-flow model of the unconfined Kirkwood-Cohansey aquifer system in the Metedeconk River and Toms River Basins in the northern half of Ocean County and southern Monmouth County. The model was used to evaluate the effects of increased groundwater withdrawals from the Kirkwood-Cohansey aquifer system on water levels in the surficial Kirkwood-Cohansey aquifer system and on base flow in the Metedeconk River and Toms River.

\section{Well Numbering System}

The well numbering system used in this report has been used by the USGS in New Jersey since 1978. The well number consists of a county code number and a sequence number assigned to the well in the county. The county codes used in this report are 05 for Monmouth County, 25 for Burlington County, and 29 for Ocean County. For example, well 29-928 is the 928th well inventoried in Ocean County.

\section{Description of Study Area}

The study area extends from the southern part of Monmouth County to the southern boundary of Ocean County; it includes parts of Freehold, Millstone, Howell, and Wall Townships and encompasses nearly all of Ocean County. The southwestern part of the study area includes eastern Burlington County, primarily Bass River Township (fig. 2). The eastern boundary extends approximately 5.5 miles east of the barrier islands into the Atlantic Ocean. The study area includes all or parts of 36 named and several unnamed surface-water basins that drain into the Atlantic Ocean or Barnegat Bay and Little Egg Harbor to the east (fig. 4), the Mullica River and Great Bay to the south, or the Delaware River to the west (fig. 1).

\section{Land Use}

Land-use and land-cover data, identified as Geographic Information and Retrieval Analysis System (GIRAS), were produced by the USGS with Landsat satellite imagery for New Jersey from the late 1960s to early 1970s. These images were manually interpreted into land-use polygons and paneled into 1:250,000 scale quadrangles. Production of this data is documented in Fegeas and others (1983). This dataset was used to determine land use for the study area in 1973 (fig. 5). The NJDEP generated and released land-use datasets for the entirety of New Jersey for 1986, 1995, 2002, and 2007. The NJDEP datasets were produced at different scales, reflecting improvements in digital imaging and processing over time. The 1986 land-use maps were produced at a scale of 1:24,000 and the 1995 land-use maps were produced at a scale of 1:12,000, whereas the 2002 and 2007 land-use maps were produced at a scale of 1:2,400. Different data resolutions and reclassification of some land parcels over time account for some differences among land-use datasets developed for different years. However, general changes in land use in the study area were evident by the comparison of the land-use data from 1973 with those of 2007 (fig. 5).

A large part of the study area is designated as the Pinelands by NJDEP (fig. 2). The Pinelands is largely undeveloped land that comprises 251,708 acres of the study area. A comparison of land-use summaries (table 1) indicates that conversion of forest, agriculture, and barren land to new urban land proceeded steadily from 1973 to 2007 outside the Pinelands. The largest decreases in acreage occurred to forested land, followed by agricultural land and barren land. A comparison of 1986 data with 2007 data indicates that nearly all of the combined loss of forest, agricultural, and barren land resulted from conversion to urban land. In 1973, urban land accounted for about 14.9 percent of all land use (excluding water). By 2007, urban land had increased to about 24.1 percent of all land use (excluding water), an increase of 47,329 acres.

A much lower acreage of wetlands is noted in the GIRAS data than in the NJDEP datasets. This difference is attributed to poor resolution of wetlands on aerial photographs at a scale of 1:250,000. Differences in acreage of water bodies between the 1973 GIRAS dataset and more recent NJDEP datasets resulted from different accounting methods; specifically, the surface area of the Barnegat Bay and Little Egg Harbor is accounted for in the NJDEP datasets, but not in the GIRAS. Therefore, net changes for water and wetlands from 1973 to 2007 were not calculated in table 1 .

\section{Population}

The population of Ocean County grew from 33,069 in 1930 to 510,916 in 2000 (Ocean County Department of Planning, 2009). The 2008 population is estimated at 569,111 (U.S. Census Bureau, 2009). Development in the county occurred along the coastal beaches and along the north-south transportation corridor formed by the Garden State Parkway and U.S. Route 9 (fig. 1). Land development west of the Garden State Parkway occurred along several east-west transportation corridors, including State Routes 526, 70, and 37 in the northern part of the county and State Route 72 in the southern part of the county. The largest total increases in population by municipality from 1930 to 2000 occurred in Toms River $(85,736)$, Brick $(74,947)$, Lakewood $(52,483)$, Jackson $(41,097)$, Berkeley $(39,180)$, and Manchester $(37,919)$ Townships; and Point Pleasant Borough $(17,248)$ in the northern part of the county; and Lacey $(24,654)$ and Stafford $(21,493)$ Townships in the central and southern part of the county (Ocean County Department of Planning, 2009).

Population increased by 20 percent for all of Ocean County between 1994 and 2004, from 461,152 to 553,251. Municipalities that exceeded the county-wide growth rate were Stafford (58.9 percent), Barnegat (41.1 percent), Little Egg Harbor (36.5 percent), and Ocean Townships (29 percent); and Surf City Borough (34.1 percent) in the southern half of the 


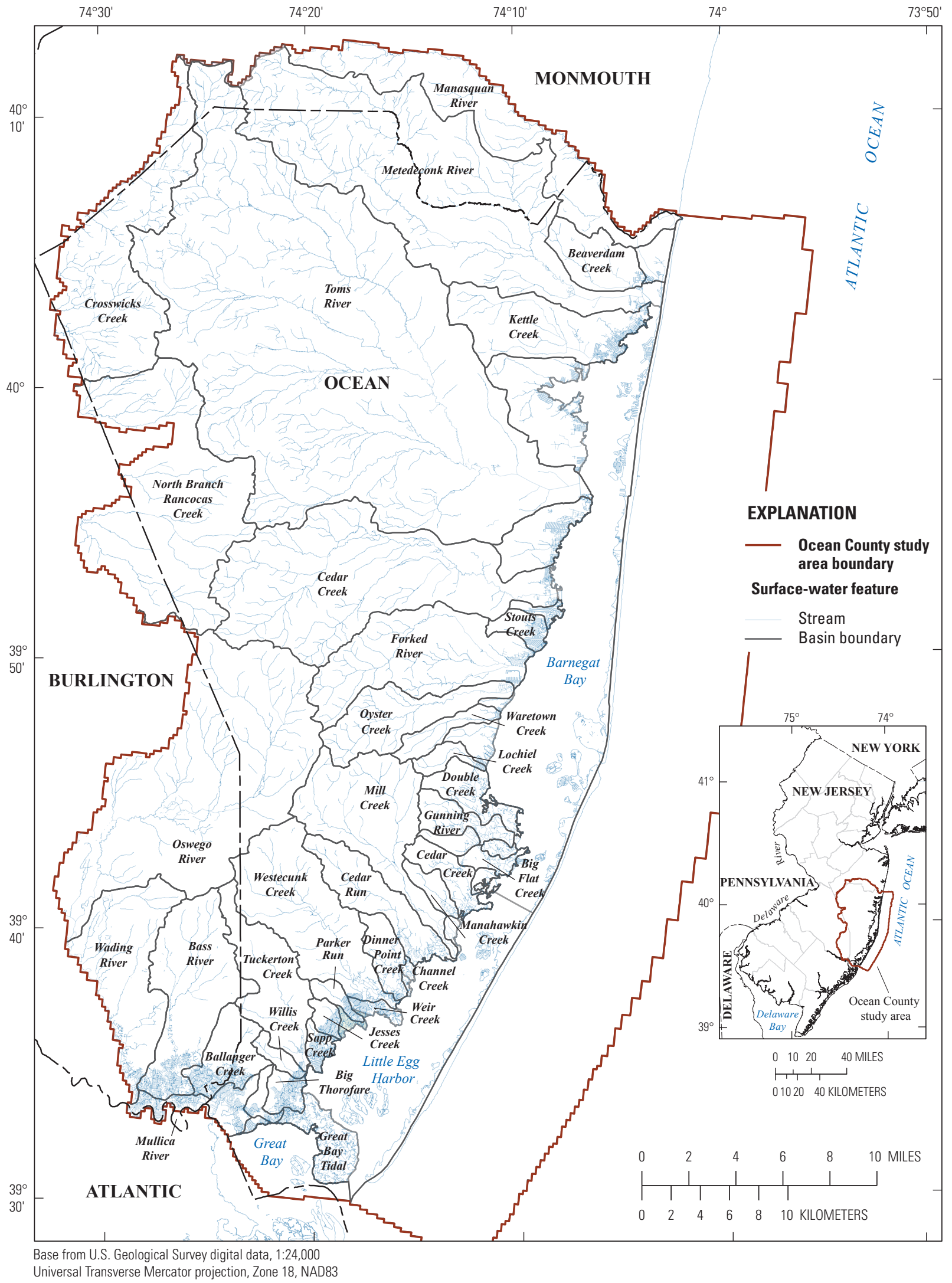

Figure 4. Location of surface-water basins, Ocean County study area, New Jersey. 

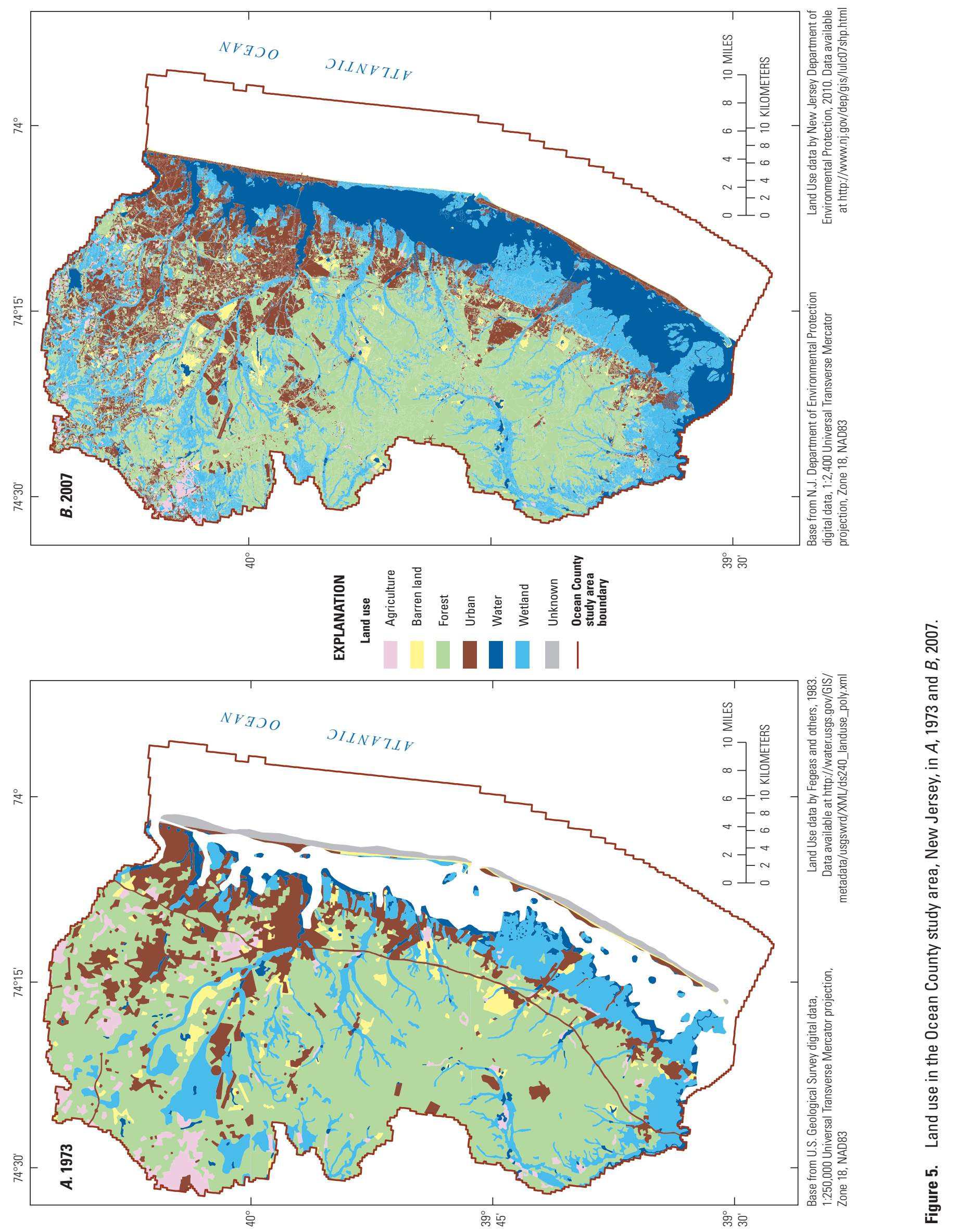
Table 1. Land use in the Ocean County study area, New Jersey.

[Location of Ocean County study area is shown in figure 1; units are acres; --, not calculated]

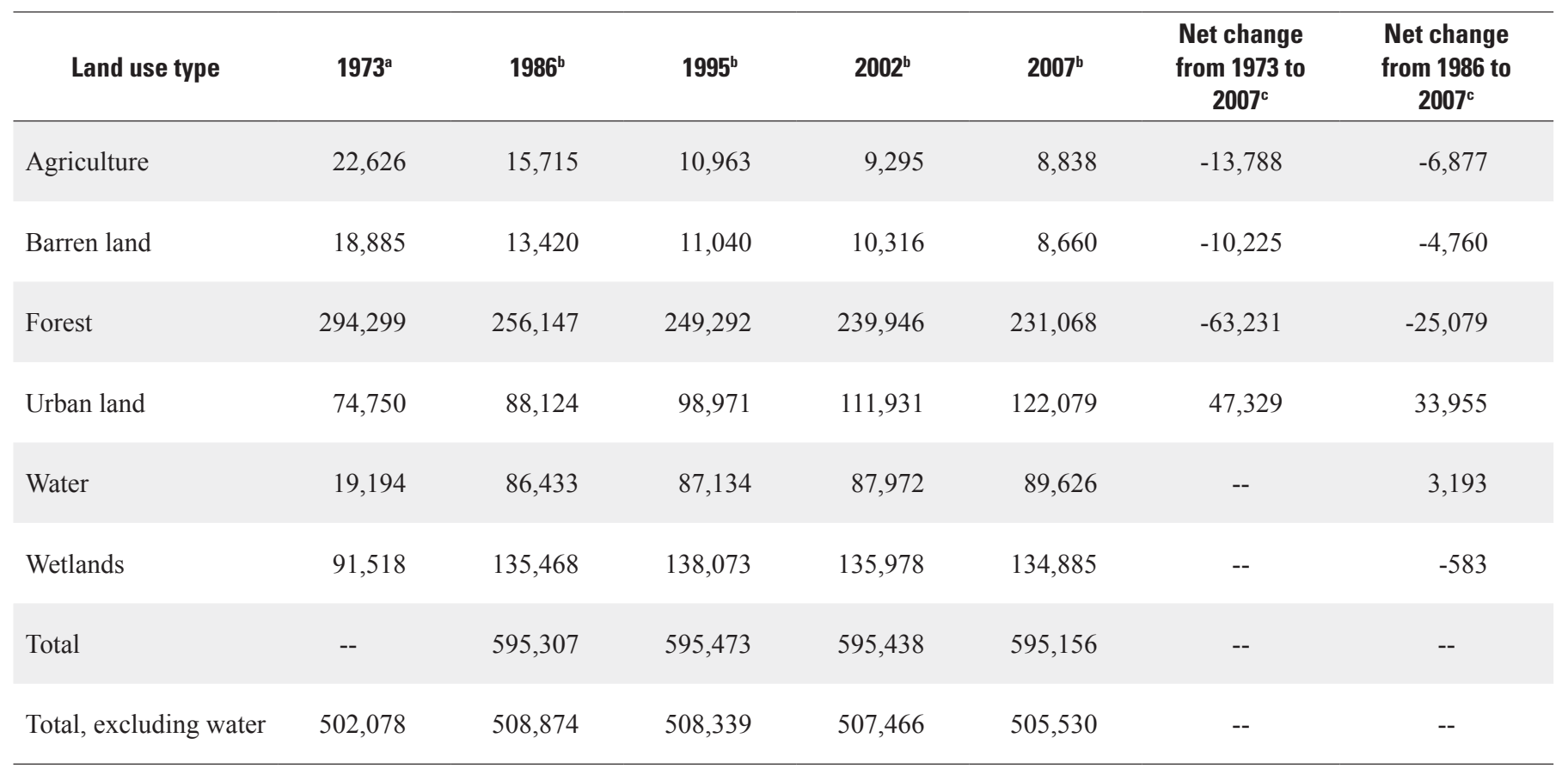

${ }^{a}$ U.S. Geological Survey Geographic Information and Retrieval Analysis System land-use data.

${ }^{b}$ New Jersey Department of Environmental Protection land-use data.

${ }^{\mathrm{c}}$ Negative values represent a decrease in acres.

county; and Jackson (39.4 percent), Lakewood (31.4 percent) and Plumsted (22.3 percent) Townships in the northern part of the county (Ocean County Department of Planning, 2006). Trends in population growth indicate which areas may experience a measureable effect on water resources in the future from continued development.

\section{Hydrogeologic Framework}

The hydrogeologic framework described in this report is based on a prior study by Zapecza (1989) and additional hydrogeologic interpretations by the New Jersey Geological and Water Survey (NJGWS) of the NJDEP (L.G. Mullikin, New Jersey Geological and Water Survey, written commun., 2001). The unconsolidated sediments described in this study (fig. 6) range in age from Holocene deposits (10,000 years before present) to the upper Paleocene Vincentown Formation (65.5 million years before present) (table 2). Pleistocene deposits of colluvium and alluvium in the subsurface and on the land surface have been mapped in detail by Newell and others (2000).

In the southern part of the study area, small pockets of the Bridgeton Formation, composed of arkosic sand with larger clasts, have been mapped at the surface. The unconsolidated middle Miocene Cohansey Formation consists of fine to coarse-grained sand and clay and underlies the surficial deposits throughout the study area. Underlying the Cohansey
Formation is the lower to middle Miocene Kirkwood Formation. The Kirkwood Formation has been mapped and subdivided into four members. These members, from youngest to oldest, are the Belleplain, Wildwood, Shiloh Marl, and Lower. The Kirkwood Formation, Cohansey Formation, and overlying undifferentiated sediments compose a seaward-dipping wedge of gravel, sand, silt, and clay that forms the unconfined Kirkwood-Cohansey aquifer system in the study area (fig. 6A). Where the layers of sediment thicken downdip in a southeasterly direction (fig. 3), the Kirkwood Formation contains a massive diatomaceous clay unit that confines the Rio Grande water-bearing zone and the Atlantic City 800-foot sand. Sugarman (2001) referred to this confining bed and the Rio Grande water-bearing zone as the Wildwood-Belleplain confining unit. The confining unit overlying the Rio Grande waterbearing zone extends southwest from just north of Barnegat Inlet in Island Beach State Park through the eastern mainland of Lacey, Ocean, Barnegat, Stafford, Eagleswood, Little Egg Harbor, and Bass River Townships (figs. 2 and 6B). A semiconfined zone, mapped by the NJGWS (L.G. Mullikin, New Jersey Geological and Water Survey, written commun., 2001), extends updip from 2 to 5 miles north and west of the area of confinement. The thickness of the Rio Grande water-bearing zone ranges from 20 to 60 feet.

The confining unit above the Atlantic City 800 -foot sand extends from approximately 4 miles north of Barnegat Inlet (located between Island Beach State Park to the north and Barnegat Light Township to the south) southwest through Bass 

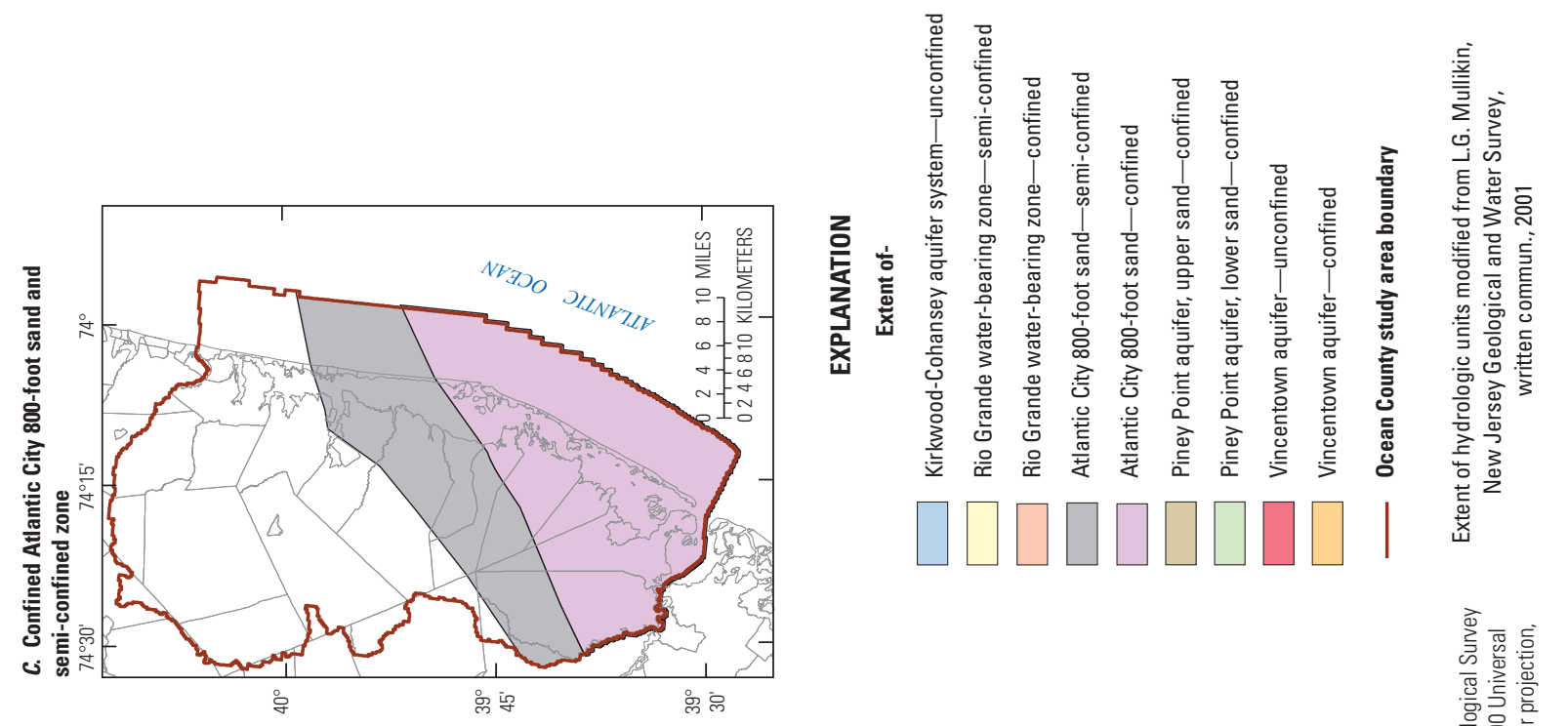

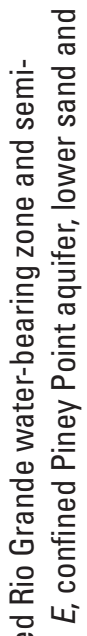

넝
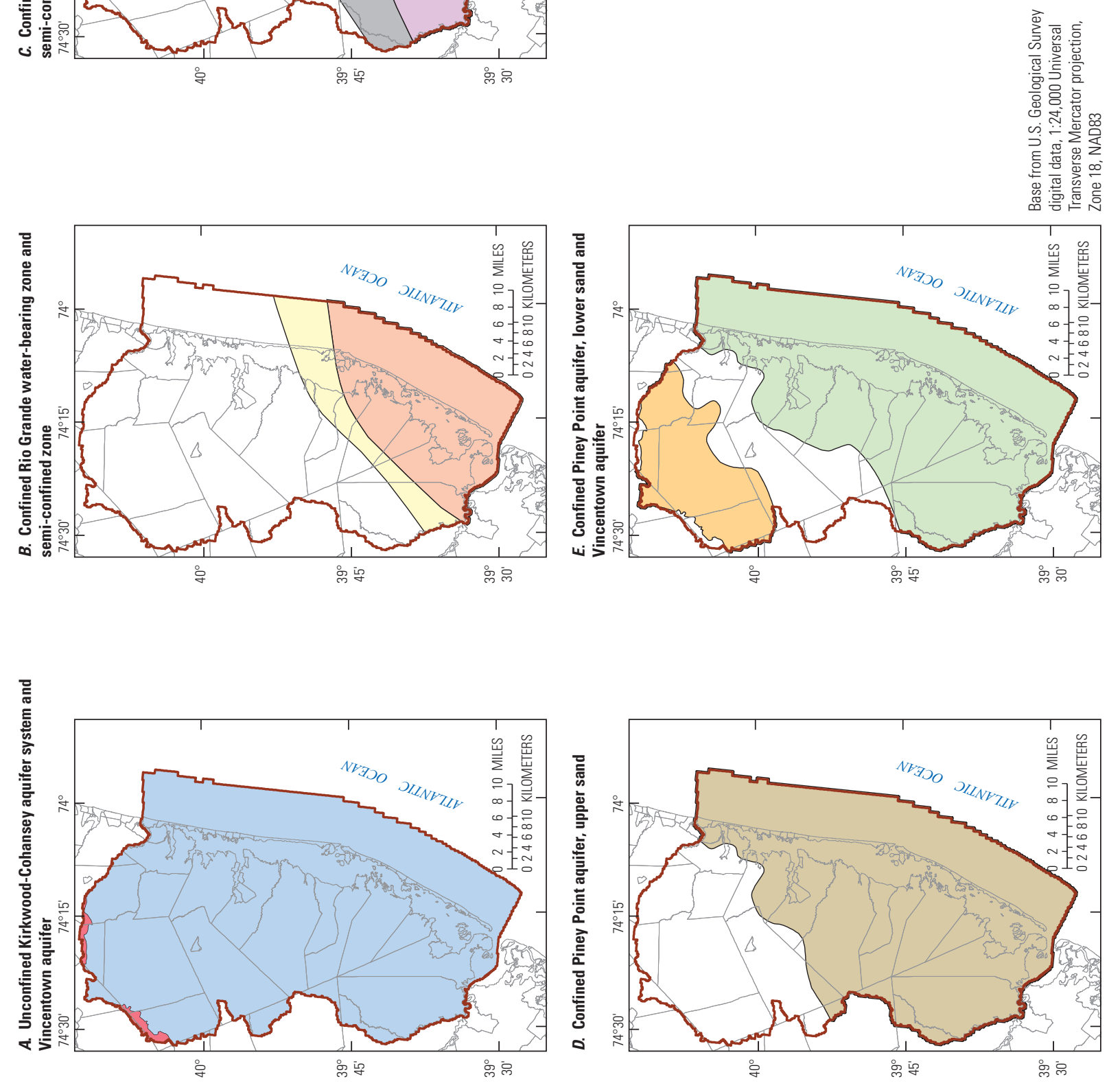

仓ั

产高

它

总

氙

듬

터웜

के

ఫั 엉

뭉

ญे

등 엄

응

ํㅗㅇ

을

立 只

밍 ฮ

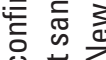

을 응 쥬

ব잉

is

言㝴㤩

음 总

응 雪

임 엉

동ํㅇ

प

产产

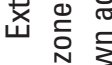

๑ 웡

온 
Table 2. Stratigraphic and hydrogeologic units, Ocean County area, New Jersey.

[Location of Ocean County study area is shown in figure 1]

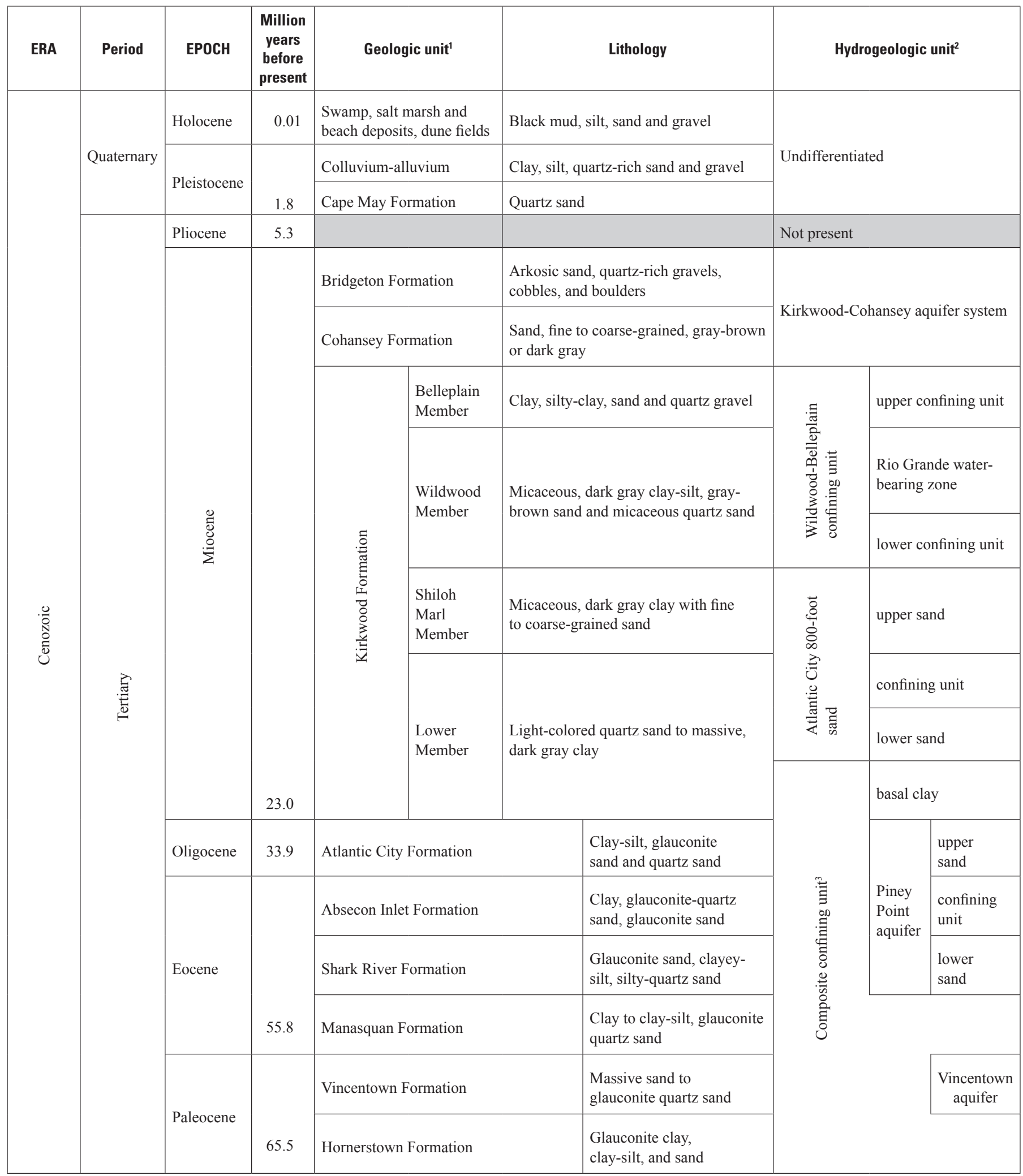

${ }^{1}$ Nomenclature from Owens and others, 1998; Newell and others, 2000.

${ }^{2}$ Nomenclature from Zapecza, 1989, and Mullikin (New Jersey Geological and Water Survey, written commun., 2001).

${ }^{3}$ Includes older geologic units not shown in table. 
River Township (figs. 2 and 6C). The semiconfined zone parallels the zone of confinement and extends from approximately 10 miles north of this designation in Lavallette Borough to 5 miles north and west in Bass River Township (L.G. Mullikin, New Jersey Geological and Water Survey, written commun., 2001). The Atlantic City 800 -foot sand is divided into, and mapped as, upper and lower sands separated by a leaky confining bed (Sugarman, 2001). From the top of the upper sand to the bottom of the lower sand, the Atlantic City 800 -foot sand is from 40 to 160 feet thick in this area.

The Lower Member of the Kirkwood Formation contains a basal clay unit that forms the top of the composite confining bed (Zapecza, 1989) and confines the Piney Point aquifer, which exists only in the subsurface. The Piney Point aquifer consists of parts of the upper Oligocene Atlantic City Formation, the lower Oligocene Sewell Point Formation (not identified in the study area), the upper Eocene Absecon Inlet Formation, and the upper to middle Eocene Shark River Formation. The NJGWS mapped distinct units in the Piney Point aquifer, including upper and lower sands with an intervening confining unit (L.G. Mullikin, New Jersey Geological and Water Survey, written commun., 2001). The upper sand extends approximately from the boundary of Manchester Township with Lacey and Berkeley Townships northeast to the Manasquan River near the boundary of Brick Township and Point Pleasant Borough (figs. 2 and $6 D$ ). The upper sand ranges in thickness from 40 to 220 feet. The extent of the lower sand is similar to the upper sand except in the western part of the study area where its northernmost extent is approximately 10 miles south of the upper sand. The thickness of the lower sand ranges from 20 feet to a maximum of 100 feet at Island Beach State Park. The lower sand is correlative with the Shark River Formation. Very few water-supply wells are known to tap this horizon. The Piney Point aquifer is used for water supply in the Toms River area and in Barnegat Light Borough (figs. 2 and $6 E$ ).

The lower Eocene Manasquan Formation stratigraphically underlies the Piney Point aquifer and confines the underlying upper Paleocene Vincentown aquifer. The Vincentown aquifer is in hydrologic contact with the KirkwoodCohansey aquifer system at the northwestern edge of the study area, where the Vincentown aquifer crops out adjacent to the western limit of the Kirkwood-Cohansey aquifer system (fig. 6A). The Vincentown aquifer extends for several miles downdip to the east where it becomes confined and truncates in the subsurface as it grades into finer-grained silts and clays (fig. $6 E$ ). The confining unit overlying the Vincentown aquifer, which does not crop out in the study area, includes sediments of the Manasquan Formation and the basal Kirkwood-Cohansey aquifer system (Zapecza, 1989). The subsurface contact between the Kirkwood-Cohansey and the Vincentown aquifers in the study area is not well mapped, primarily due to the Vincentown aquifer's limited extent and the sparse distribution of wells that traverse this zone. The easternmost extent of the Vincentown aquifer approximately parallels the boundary of Manchester Township with Plumsted and Jackson Townships northeast to the Manasquan River (fig. 4) near the border with Wall and Brick Townships. The Vincentown aquifer ranges in thickness from 20 to 100 feet, where confined.

\section{Groundwater Withdrawals}

The NJDEP Bureau of Water Supply requires well owners to report monthly withdrawals for all wells within the State that have a pump capable of extracting 70 gallons per minute or greater. Owners of private domestic wells are not required to report water use; therefore, domestic self-supply is not included in this study. The NJDEP maintains records for all reported water-use wells, categorized by type of water use and pump capacity (table 3). Wells in the 5000, 2000P, and $10000 \mathrm{~W}$ permit series are metered, but wells with an agricultural certification are not. Withdrawals from wells with agricultural certification are estimated and are generally based on pump capacity multiplied by the number of hours the pump operated. Monthly water-use records with reported values from 2000 to 2003, compiled by the NJDEP, were used to calculate annual withdrawals from the 682 wells screened in the Kirkwood-Cohansey aquifer system, Rio Grande water-bearing zone, Atlantic City 800-foot sand, Piney Point aquifer, and Vincentown aquifer in the Ocean County study area (fig. 7). Groundwater withdrawals in the Ocean County study area from the aquifers studied increased from approximately 12.5 billion gallons in 2000 to approximately 14 billion gallons per year from 2001 to 2003 (fig. 8). Withdrawals from the Kirkwood-Cohansey aquifer system range from

Table 3. New Jersey Department of Environmental Protection water allocation permit series.

[gal/d, gallons per day; <, less than; >, greater than]

\begin{tabular}{|c|c|c|c|c|}
\hline Allocation permit series & Magnitude of withdrawal & Primary use & Source & $\begin{array}{c}\text { Number of wells in } \\
\text { study area }\end{array}$ \\
\hline 5,000 & High volume (> 100,000 gal/d) & Public-supply & Groundwater & 182 \\
\hline $10,000 \mathrm{~W}$ & Low volume $(<100,000 \mathrm{gal} / \mathrm{d})$ & Institutional, recreation & Groundwater & 204 \\
\hline Total & & & & 682 \\
\hline
\end{tabular}




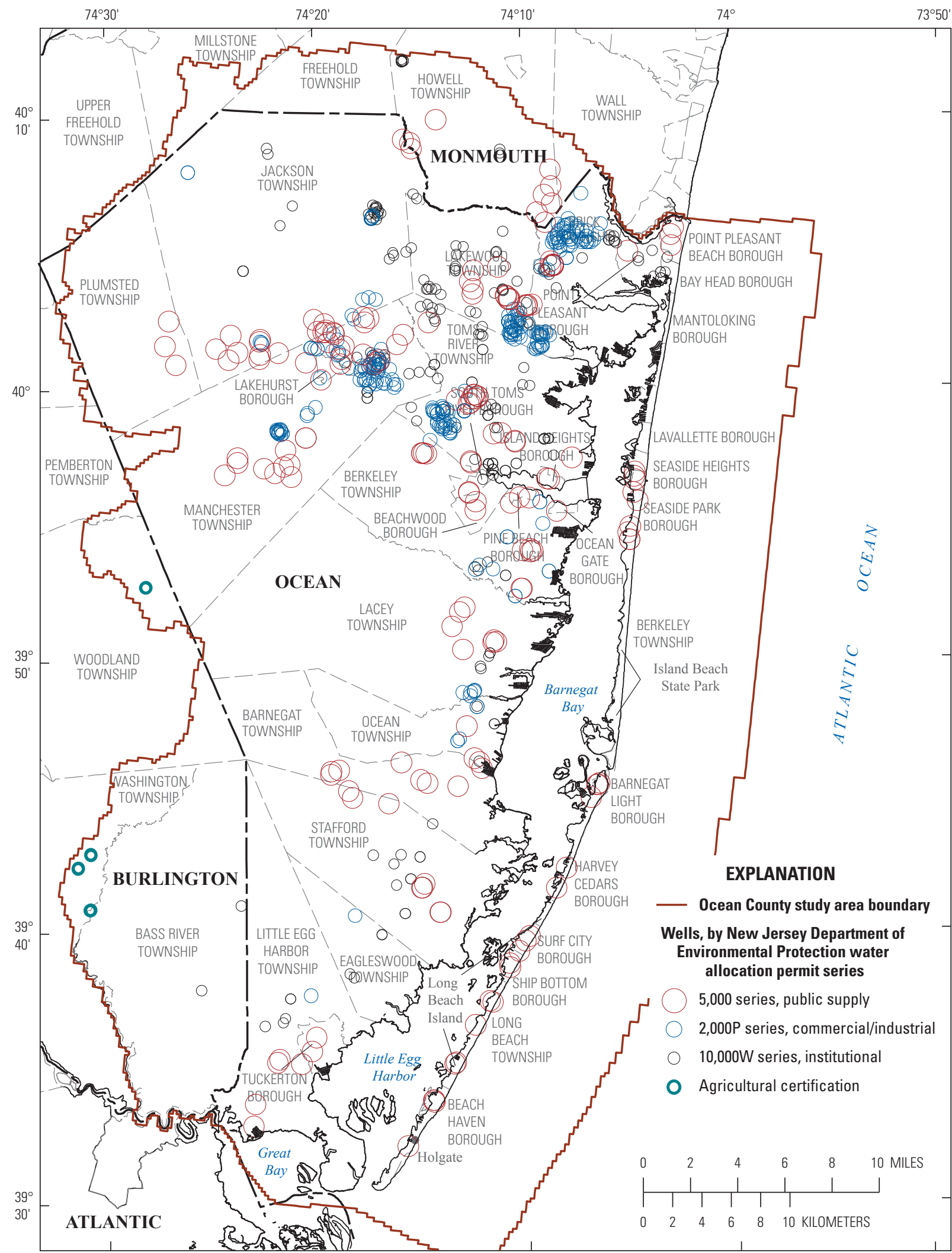

Base from U.S. Geological Survey digital data, 1:24,000

Universal Transverse Mercator projection, Zone 18, NAD83

Figure 7. Location of groundwater-withdrawal wells screened in the Kirkwood-Cohansey aquifer system, Rio Grande water-bearing zone, Atlantic City 800-foot sand, Piney Point aquifer, and Vincentown aquifer, Ocean County study area, New Jersey, with withdrawal records from 2000 to 2003. 


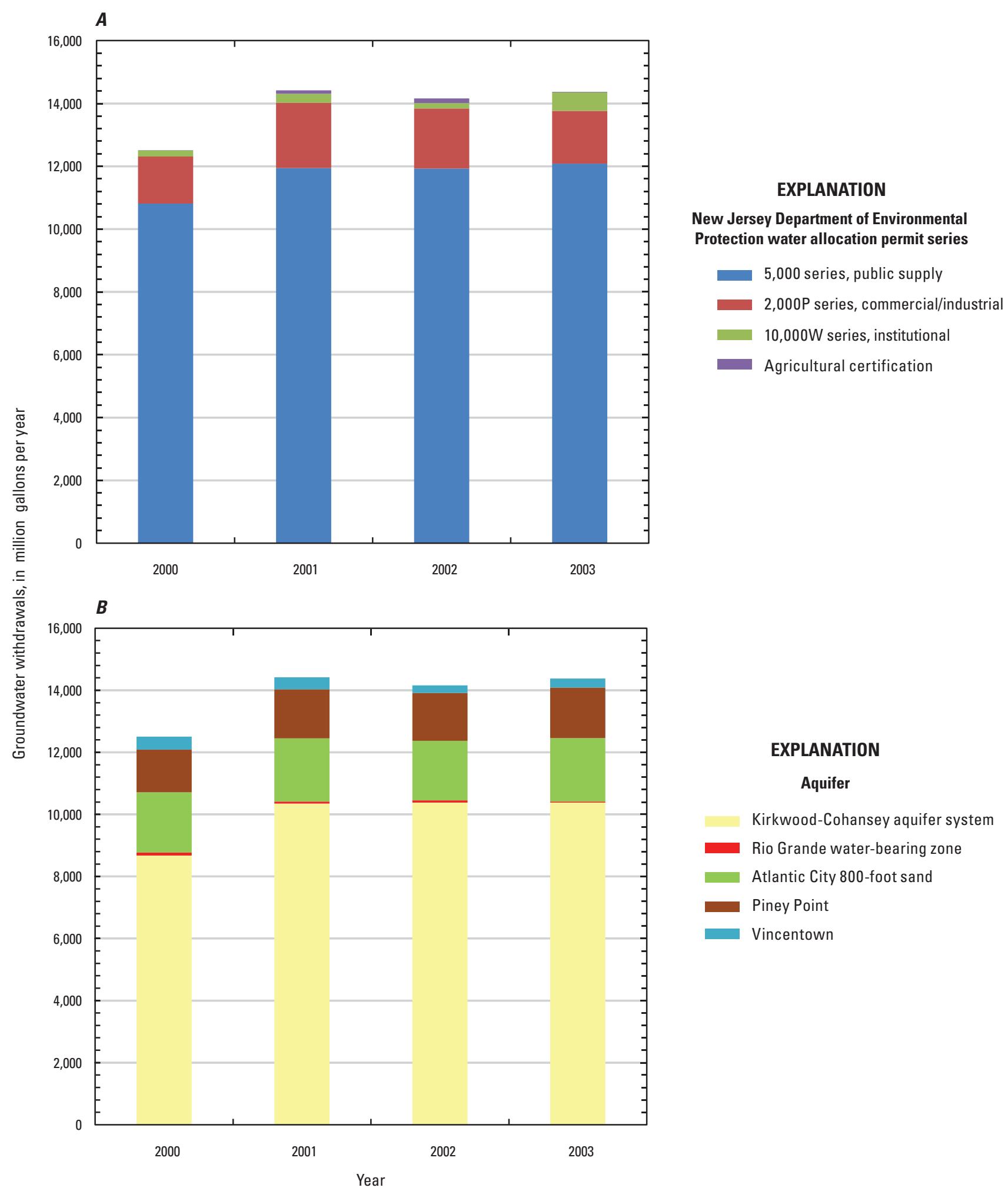

Figure 8. Reported annual groundwater withdrawals by: $A$, water allocation permit series and $B$, aquifer, 0 cean County study area, New Jersey, from 2000 to 2003. 
8.6 to 10.3 billion gallons per year and exceed the combined withdrawals from the other aquifers investigated in the Ocean County study area.

\section{Simulation of Groundwater Flow}

A three-dimensional groundwater-flow model of the Kirkwood-Cohansey aquifer system, Rio Grande water-bearing zone, Atlantic City 800-foot sand, Piney Point aquifer, and Vincentown aquifer was developed by creating a mathematical representation of the regional hydrogeologic framework and flow system. The USGS modular finite-difference, groundwater-flow model, MODFLOW-2005, is used in this study (Harbaugh, 2005). The model code is designed and developed for use with packages that add functionality to the core program. Several MODFLOW packages, including the Basic (BA6), Discretization (DIS), Layer Property Flow (LPF), Recharge (RCH), Well (WEL), River (RIV), Drain (DRN), Flow and Head Boundary (FHB1), Zone (ZONE), and Multiplier (MULT), were used to represent the flow system in the Ocean County study area. The FHB1 package is documented in Leake and Lilly (1997).

Hydraulic properties used in the model were initially estimated from aquifer tests and published hydrogeologic and modeling studies of the aquifers of interest. Initial values were revised during model calibration. Groundwater withdrawals were taken from withdrawal records and entered as pumping rates for each stress period. They are simulated in the groundwater-flow model by using the WEL package. The following sections describe the groundwater-flow model in detail and include the model discretization, model stresses, boundary conditions, and calibration evaluation.

\section{Model Discretization}

The study area is discretized into a variably spaced model grid that is rotated -6 degrees from north. The model grid approximately parallels the coastline of northern Ocean County and has a uniform spacing of 800 feet (ft), west to east, and $800 \mathrm{ft}$, north to south, over the land mass. Grid-cell dimensions increase to the east over the Atlantic Ocean to a maximum of 2,400 ft, west to east, and remain at $800 \mathrm{ft}$, north to south (fig. 9). There are 196 columns and 344 rows. The number of cells per layer is 67,424 . The areal extent of the entire model grid is approximately 1,732 square miles $\left(\mathrm{mi}^{2}\right)$ and the active area of the model is $1,185 \mathrm{mi}^{2}$.

The vertical dimension of the hydrogeologic framework included in this investigation, extends from land surface through the subsurface to the bottom boundary of either the Vincentown aquifer or the lower sand of the Piney Point aquifer with underlying clay units. The groundwater-flow system is divided into 11 model layers, on the basis of the framework of the New Jersey Coastal Plain by the USGS (Zapecza, 1989) and on the updated hydrogeologic framework interpretations of Ocean County by the NJGWS (L.G. Mullikin, New Jersey Geological and Water Survey, written commun., 2001). Contours of the top of hydrogeologic units provided by the NJGWS form the basis for most of the model layers, particularly the top surface of each aquifer. The interpretation of the bottom of the unconfined Kirkwood-Cohansey aquifer system coincident with the top of the confining unit overlying the Rio Grande water-bearing zone by Zapecza (1989) delineates the top of model layer 2. All model layers were extrapolated to be continuous throughout the area of active model cells. Where hydrogeologic units were interpreted to pinch out in the subsurface, the model layer thickness and hydraulic properties were set to represent flow properties of a different lithology (fig. 3).

Hydrostratigraphic interpretations of the Ocean County study area by NJGWS indicate subsurface zones of reduced permeability updip (northwest) from the confined Rio Grande water-bearing zone and the Atlantic City 800-foot sand (L.G. Mullikin, New Jersey Geological and Water Survey, written commun., 2001). In plan view, the semiconfined zones represent a transition from the clay units overlying the Rio Grande water-bearing zone and the Atlantic City 800 -foot sand to the undifferentiated sands of the Kirkwood-Cohansey aquifer system (fig. 6). In vertical section, the semiconfined zones represent a gradational zone of sands and clays between the unconfined Cohansey Formation and the Kirkwood Formation sand, and the confined part of the Kirkwood Formation to the southeast (fig. 3). Vertical discretization of model layers 2 through 7 includes these semiconfined zones, which extend several miles northwest of the Rio Grande water-bearing zone and Atlantic City 800-foot sand. In this report, potentiometricsurface maps of the Rio Grande water-bearing zone and Atlantic City 800-foot sand (model layers 3, 5, and 7) include this area.

Wells within these semiconfined zones that contain a well screen within layers 1 to 7 are considered screened in the undifferentiated Kirkwood-Cohansey aquifer system. The aquifer designation of each well is derived from the USGS Ground Water Site Inventory (GWSI) database. Aquifer designations are based upon geologic maps, aquifer thickness, screen depth and either a driller's log or a geophysical log of the bore hole or well, if available.

Streams, ponds, and lakes are simulated by using a combination of the MODFLOW River package and Drain package. All surface-water features in the groundwater-flow model are derived from the geographical representation of their extent in the USGS 1:24,000 scale National Hydrography Dataset (NHD) - a feature-based database that interconnects and uniquely identifies the stream segments or reaches that make up the surface-water drainage system throughout the country.

Time in the groundwater-flow model is set to units of seconds. The simulation period of the model is from January 2000 through December 2003; a total of 89 stress periods ${ }^{1}$ are used.

${ }^{1}$ Stress period - the computational time intervals in a MODFLOW simulation. Transient stresses change at the beginning of a stress period. 


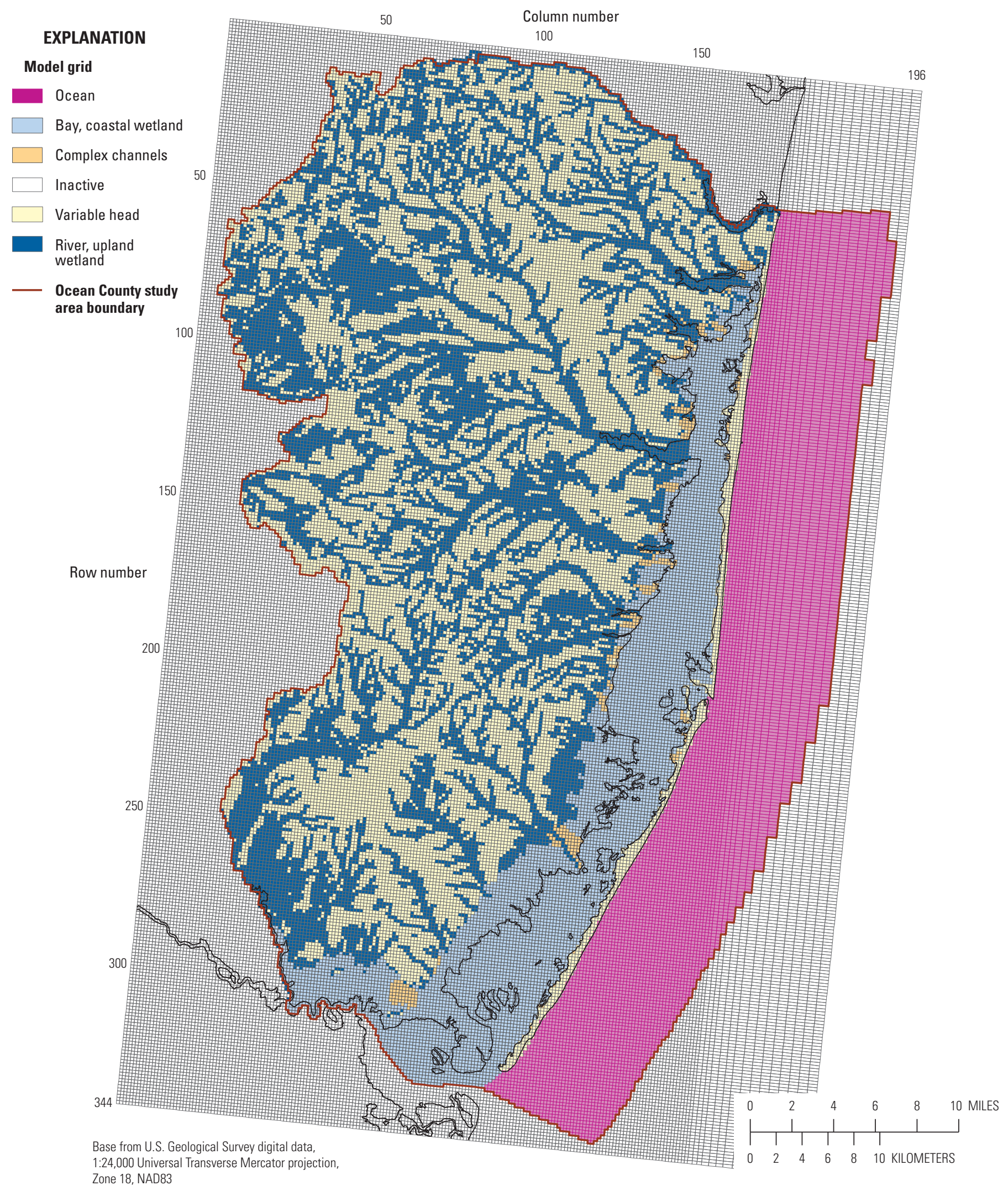

Figure 9. Variably spaced model grid, lateral boundaries, and representation of water bodies in the 0cean County study area, New Jersey. 
The first five stress periods are steady-state initial conditions, representing average recharge and withdrawal conditions from January 1 through December 31, 2000, repeated five times. Stress periods 6 through 41 are transient stress periods representing year 2000 monthly stresses, repeated three times. This creates a transition from steady-state average 2000 conditions to the transient period used for model calibration. The calibration period extends from stress period 42 through 89 , which are each 1 month in duration and represent January 1, 2000, through December 31, 2003. The simulation results of the yearly steady-state and monthly transitional stress periods, $1-41$, are not used in the model calibration.

\section{Boundary Conditions}

The top boundary of the flow model is the free surface of the water table (fig.3; table 4). Land areas are represented by variable head cells with groundwater recharge applied to the top surface. Where land surface is beneath Barnegat Bay, Little Egg Harbor, Great Bay, or the Atlantic Ocean, the top boundary is represented by constant head cells. Additional areas of constant head cells include small sedge islands, primarily in Little Egg Harbor, and shoreline land masses that are large coastal wetland areas (fig. 3). Streams and inland wetland areas are represented as specified-head boundaries by using either the RIV or DRN package.

The FHB1 package provides a way to apply specified heads, or specified flow at boundary cells from a larger-scale model, such as New Jersey RASA. The New Jersey RASA model (Voronin, 2004) was revised to include a model layer representing the Rio Grande water-bearing zone. Revisions to the New Jersey RASA model are documented in Pope and others (2012). Flows generated from simulation of the revised RASA model were used at corresponding cells as input to the FHB1 Package to incorporate flow at lateral and bottom model boundaries.

The bottom boundary of the model is a flow boundary representing the movement of water at the bottom contact of a confined aquifer with an underlying clay unit within the composite confining unit (table 2). The bottom boundary in the northern part of the study area is between the base of the Vincentown aquifer and the top of the Hornerstown Formation. Farther to the southeast, the bottom boundary is the contact between the bottom of the lower sand of the Piney Point aquifer and the top of the Manasquan Formation. Flow at the bottom boundary is simulated with the FHB1 Package.

The lateral flow boundaries of the study area are coincident with a variety of hydrologic features. The northwestern boundary corresponds to the northwestern extent of the

Table 4. Groundwater model layers and corresponding hydrogeologic units in the Ocean County study area, New Jersey.

[Location of Ocean County study area is shown in figure 1]

\section{Model layer \\ Primary hydrogeologic units}

1 Unconfined Vincentown aquifer (in the northwest part of the study area) and Kirkwood-Cohansey aquifer system

2 Vincentown aquifer, Kirkwood-Cohansey aquifer system, and confining unit overlying the Rio Grande water-bearing zone

3 Vincentown aquifer, Kirkwood-Cohansey aquifer system, and Rio Grande water-bearing zone

4 Vincentown aquifer, Kirkwood-Cohansey aquifer system, and confining unit overlying the Atlantic City 800-foot sand, upper sand

5 Vincentown aquifer, Kirkwood-Cohansey aquifer system, and Atlantic City 800-foot sand, upper sand

6 Vincentown aquifer, Kirkwood-Cohansey aquifer system, and confining unit overlying the Atlantic City 800-foot sand, lower sand

7 Vincentown aquifer, Kirkwood-Cohansey aquifer system, and Atlantic City 800-foot sand, lower sand

8 Vincentown aquifer and confining unit overlying the Piney Point aquifer, upper sand, and Kirkwood-Cohansey aquifer system in localized areas

9 Vincentown aquifer and Piney Point aquifer, upper sand, and Kirkwood-Cohansey aquifer system in localized areas

10 Vincentown aquifer, confining unit overlying the Vincentown aquifer, and confining unit overlying the Piney Point aquifer, lower sand

11 Vincentown aquifer and Piney Point aquifer, lower sand 
Vincentown aquifer. The northeastern boundary is the center of the main branch of the Manasquan River, and the southern boundary is the center of the main channel of Wading River, Mullica River, and Great Bay. The eastern boundary is approximately 5.5 miles east of the barrier island in the Atlantic Ocean. The western boundary from south to north corresponds to the basin boundary of Oswego River and subbasin divides within the Mount Misery Brook, Pole Bridge Branch, and Jumping Brook Basins, and a portion of Lahaway Creek. The FHB1 Package is also used to incorporate boundary flow in model layers 1 and 3 for no-withdrawal conditions dependent upon the cell-by-cell budget determination at corresponding cell faces in the RASA model. Published prepumping heads (Zapecza and others, 1987) are used to specify boundary heads for layers 5, 7, 9 and 11 (Atlantic City 800-foot sand, Piney Point and Vincentown aquifers) for no-withdrawal conditions. Simulated boundary flows derived from the revised RASA model are used for layers 1 and 3 of the Ocean County study area model because published prepumping heads for the Rio Grande (model layer 3) do not exist. The FHB1 Package is also used to incorporate boundary flows from the revised RASA model in model layers 1, 3, 5, 7, 9, and 11 for the years 2000 to 2003.

All streams and lakes are represented in the groundwaterflow model by using the RIV package. Ponds and upland wetland areas disconnected from stream reaches are represented in the groundwater-flow model by using the DRN package. Barnegat Bay-Little Egg Harbor, Great Bay, and any low-lying islands in the bay are represented as constant head cells with a water level of 0 feet. Wetland areas in the southern part of the study area are represented in the NHD by interconnected channels adjacent to the shoreline and generally had an altitude of 5 feet or less. These areas are simulated as constant head cells.

\section{Recharge}

In the groundwater-flow model, recharge to the unconfined surficial aquifer is a flux across the water table, simulated as a volume of water applied to the top area of each model cell in layer 1 per unit of time. Researchers have used a variety of methods to estimate recharge in the New Jersey Coastal Plain, including water-budget analysis that accounts for soil type and land use (Charles and others, 1993) and calculations of unsaturated flow using moisture-content data (Baehr and others, 2003). Watt and others (1994) used a water-budget analysis to estimate recharge in the Metedeconk River Basin and the Toms River Basin with precipitation and discharge data from 1980 through 1989. Watt and others (1994) estimated an annual recharge rate of 15.45 inches per year (in/yr) in the Metedeconk River Basin and $19.4 \mathrm{in} / \mathrm{yr}$ in the Toms River Basin. Nicholson and Watt (1997) estimated different recharge rates on the basis of geology of the underlying sediments and the percentage of urban land use in the Metedeconk River and Toms River Basins. In that study, recharge of 13.4 to $17.3 \mathrm{in} / \mathrm{yr}$ is estimated for urban land, and 16.8 to $21.6 \mathrm{in} / \mathrm{yr}$ is estimated for non-urban land. Gordon (2004) conducted an investigation of water resources in the southern part of Ocean County that includes Cedar Creek, Forked River, Oyster Creek, Mill Creek, Cedar Run, Dinner Point Creek, Westecunk Creek, and Tuckerton Creek Basins. Gordon (2004) estimated a recharge rate of $17.5 \mathrm{in} / \mathrm{yr}$. The NJGWS used land use, land cover, soil and climate data to derive and map estimates of groundwater recharge throughout New Jersey (New Jersey Geological and Water Survey, 2005). Groundwater recharge rates are generated at a resolution of 1 acre or greater for all parcels of land in New Jersey. Using the NJGWS method, two distinct areas of different recharge rates are produced, whereas water-budget methods generate a uniform rate over the entire Ocean County study area that varies with time. Annual recharge in the Ocean County study area varies from no recharge in wetland areas to $18 \mathrm{in} / \mathrm{yr}$ in upland areas, using the NJGWS methodology.

A monthly recharge rate is estimated for 1990 to 2003 in the Ocean County study area using a modified water balance method that incorporates the effect of land use by factoring spatially uniform estimated monthly rates with the spatially variable annual recharge data. The water balance method described in Nicholson and Watt (1997) is used in this study to calculate daily recharge and sum it by month; the method is modified slightly so that infiltration values are not time lagged. Calculation of recharge, a multistep process, is presented in equations 1 and 2. Equation 1 estimates the daily surplus precipitation (Daily Surplus PPT) or the amount of precipitation available for groundwater recharge.

$$
\begin{gathered}
\text { Daily Surplus PPT = Daily PPT-Daily } \\
\text { PET - Daily SMD }(d-1)
\end{gathered}
$$

where

$$
\begin{aligned}
& \text { Daily PPT is daily value of measured precipitation, in } \\
& \text { inches; } \\
& \text { Daily PET is daily value of estimated potential } \\
& \text { evapotranspiration, in inches; and }
\end{aligned}
$$

Daily SMD

$(d-1) \quad$ is daily value of soil moisture deficit from the previous day $(d-1)$, in inches.

Estimates of monthly groundwater recharge (Monthly $G W$

Recharge) are derived by summing the daily surplus precipitation for each month and subtracting the monthly direct runoff for the same month (equation 2).

$$
\begin{gathered}
\text { Monthly GW Recharge = Monthly Surplus } \\
\text { PPT-Monthly DRO }
\end{gathered}
$$

where

\section{Monthly Surplus \\ $P P T \quad$ is monthly total of daily values of remaining precipitation, in inches, and \\ Monthly DRO is monthly total of direct runoff, in inches.}

Precipitation, direct runoff, and potential evapotranspiration vary spatially between the northern and southern parts of the Ocean County study area. In general, the north has higher precipitation, higher direct runoff, and lower potential 
evapotranspiration rates than the south. These differences are the basis for using two recharge zones with different time-dependent values in each zone. Monthly values for each recharge zone are averaged to determine a 14-year monthly average. The monthly values are divided by the 14-year monthly average to establish a monthly rate multiplier for use with the NJGWS groundwater recharge data.

Average yearly recharge in the NJGWS geospatial recharge data is assigned to each model cell. Recharge is set to zero at cells that simulate groundwater-discharge areas, such as wetlands. The average yearly recharge for each model cell is converted to a monthly value and multiplied by the monthly rate multiplier to provide monthly recharge for each model cell. These values are increased by a multiplication factor during model calibration to provide a better match between measured and simulated base-flow values. For the years 2000 through 2003, the simulated annual recharge for all model cells in layer 1 ranges from a low of $12.42 \mathrm{in} / \mathrm{yr}$ in 2001 to a high of $21.20 \mathrm{in} / \mathrm{yr}$ in 2002 (fig. 10).

\section{Hydrologic Properties}

Previous hydrologic investigations of the New Jersey Coastal Plain reported values of horizontal and vertical hydraulic conductivity, specific yield, and storage coefficient for the Kirkwood-Cohansey aquifer system, Rio Grande water-bearing zone, Atlantic City 800 -foot sand, and Piney Point and Vincentown aquifers; vertical hydraulic conductivity was reported for the intervening confining units (table 5). The calibrated flow model applies hydraulic parameter values (table 6) to each hydrogeologic unit to simulate groundwater flow in the Ocean County study area.

Streambed hydraulic conductivity of 0.35 feet per day and drain hydraulic conductivity of 0.25 feet per day are used to calculate the conductance of river and drain cells. These values are similar to those used in a simulation of the water table in the Mullica River Basin, New Jersey (Harbaugh and Tilley, 1984). Streambed thickness is estimated at 3 feet. The river conductance for each cell is calculated as a product of the area within a cell, the streambed hydraulic conductivity, and the streambed thickness.

\section{Transient Calibration}

When evaluating the adequacy of model calibration, Reilly and Harbaugh (2004) state that "a reasonable representation of the conceptual model and sources of water is more important than blindly minimizing the discrepancy between simulated and observed heads." For this model, several types of data are used for comparison of measured and simulated

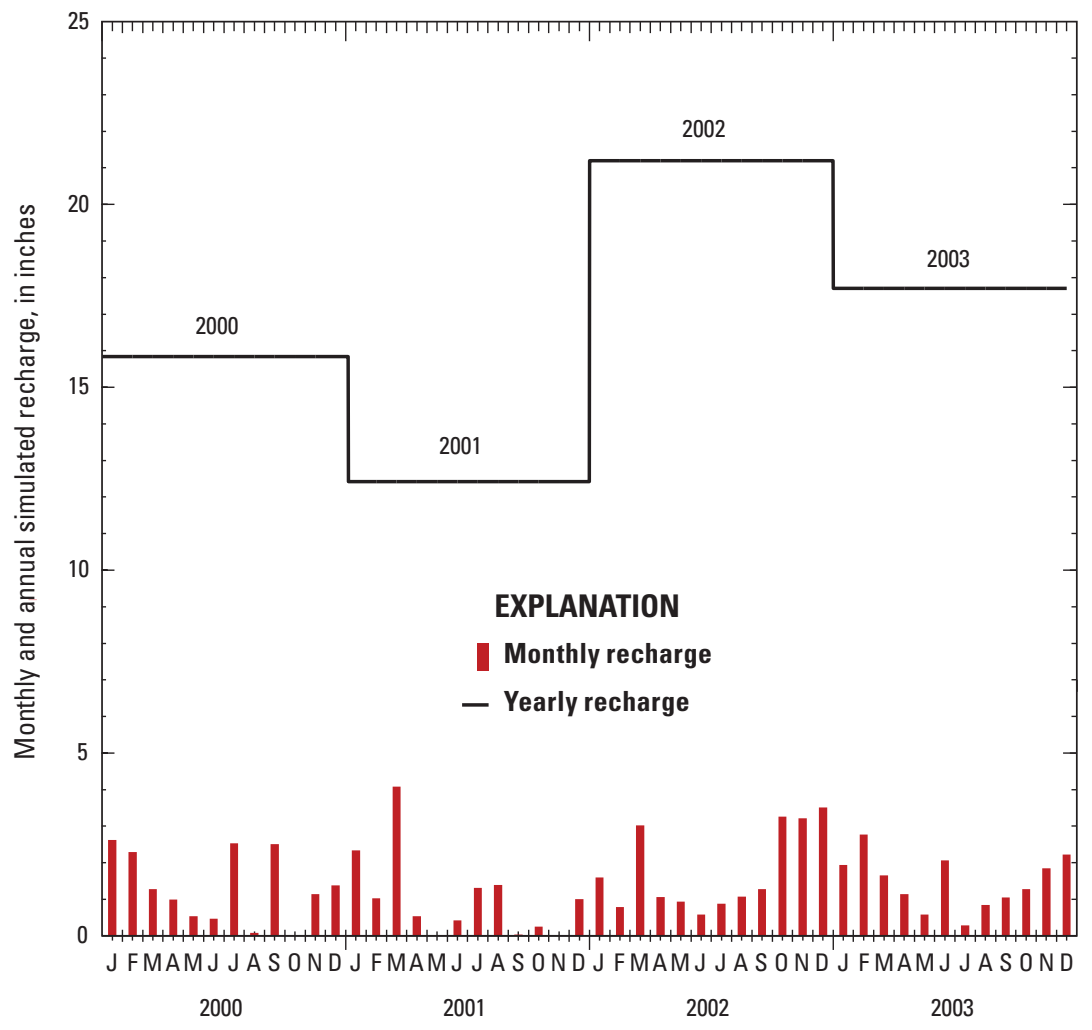

Figure 10. Monthly and annual simulated recharge, 2000 to 2003, Ocean County study area, New Jersey. 
Table 5. Published hydraulic properties of aquifers and confining units in the Coastal Plain of New Jersey.

[ft/d, feet per day; avg, average; NA, not available]

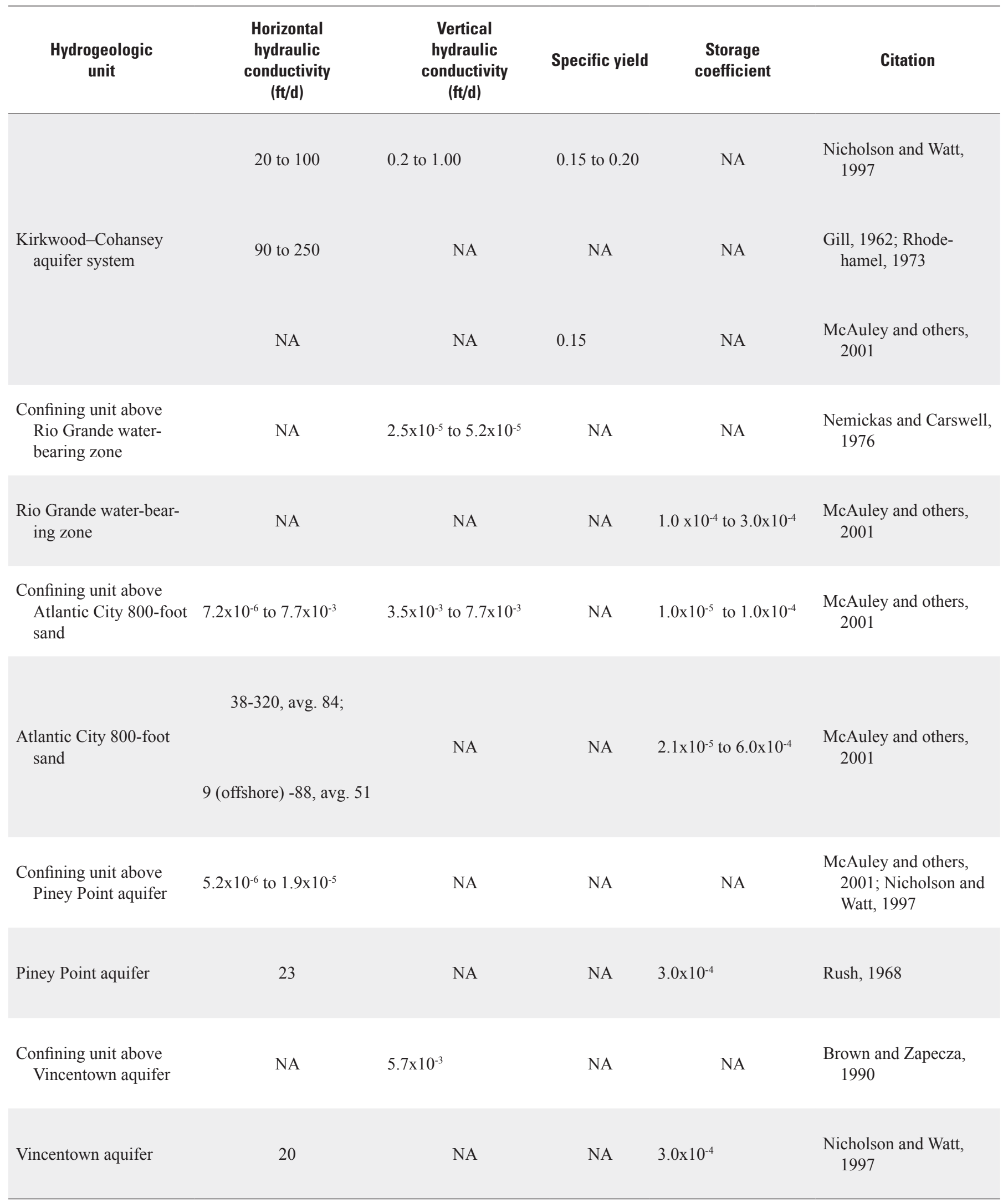


Table 6. Hydraulic properties used in groundwater-flow model simulations for the Ocean County study area, New Jersey.

[Location of Ocean County study area is shown in figure 1; LPF, layer property flow; ft/d, feet per day; NA, not applicable]

\begin{tabular}{|c|c|c|c|c|c|c|}
\hline $\begin{array}{l}\text { Hydrogeologic } \\
\text { unit }\end{array}$ & $\begin{array}{l}\text { Model } \\
\text { layer }\end{array}$ & $\begin{array}{c}\text { LPF } \\
\text { Package } \\
\text { parameter }^{\mathrm{a}}\end{array}$ & $\begin{array}{l}\text { Horizontal } \\
\text { hydraulic } \\
\text { conductivity } \\
\text { (ft/d) }\end{array}$ & $\begin{array}{c}\text { Vertical } \\
\text { hydraulic } \\
\text { conductivity } \\
\text { (ft/d) }\end{array}$ & $\begin{array}{l}\text { Specific } \\
\text { storage }\end{array}$ & $\begin{array}{l}\text { Specific } \\
\text { yield }^{c}\end{array}$ \\
\hline $\begin{array}{l}\text { Kirkwood-Cohansey aquifer } \\
\text { system }\end{array}$ & 1 to 7 & $\begin{array}{l}\text { hk12, hk13, } \\
\text { hk14, hk15, } \\
\text { hk23, hk48 }\end{array}$ & 18 to 150 & 0.2 to 1.8 & $7.5 \times 10^{-4}$ & 0.15 to 0.2 \\
\hline $\begin{array}{l}\text { Confining unit above Rio } \\
\text { Grande water-bearing zone }\end{array}$ & 2 & hk25 & $4.235 \times 10^{-4}$ & $4.235 \times 10^{-5}$ & $1.0 \times 10^{-7}$ & NA \\
\hline Rio Grande water-bearing zone & 3 & hk37 & 15 & 1.5 & $1.0 \times 10^{-6}$ & NA \\
\hline $\begin{array}{l}\text { Atlantic City } 800 \text {-foot sand, } \\
\text { upper sand }\end{array}$ & 5 & hk511, hk512 & 20 to 40 & 2.0 to 4.0 & $1.0 \times 10^{-5}$ & NA \\
\hline $\begin{array}{l}\text { Confining unit above Atlantic } \\
\text { City } 800 \text {-foot sand, lower } \\
\text { sand }\end{array}$ & 6 & hk614 & $4.235 \times 10^{-2}$ & $4.235 \times 10^{-3}$ & $1.0 \times 10^{-7}$ & NA \\
\hline $\begin{array}{l}\text { Atlantic City } 800 \text {-foot sand, } \\
\text { lower sand }\end{array}$ & 7 & hk715, hk716 & 35 & 3.5 & $1.0 \times 10^{-5}$ & NA \\
\hline Piney Point aquifer, upper sand & 9 & $\begin{array}{l}\text { hk920, hk921, } \\
\text { hk922 }\end{array}$ & 5 to 12 & 0.5 to 1.2 & $1.0 \times 10^{-5}$ & NA \\
\hline $\begin{array}{l}\text { Confining unit above Piney } \\
\text { Point aquifer, lower sand }\end{array}$ & 10 & hk1023 & $3.55 \times 10^{-3}$ & $3.55 \times 10^{-4}$ & $1.0 \times 10^{-7}$ & NA \\
\hline Piney Point aquifer, lower sand & 11 & hk1126 & 12 & 1.2 & $1.0 \times 10^{-5}$ & NA \\
\hline Vincentown aquifer & 1 to 11 & $\begin{array}{l}\text { hk11, hk21, } \\
\text { hk1124 }\end{array}$ & 20 & 0.2 to 2.0 & $\begin{array}{l}7.5 \times 10^{-4} \\
1.0 \times 10^{-6}\end{array}$ & NA \\
\hline
\end{tabular}

aParameters in the LPF Package are a combination of a prefix, layer number and zone number. The prefix, hk corresponds to horizontal conductivity. For example, hvk715 is the horizontal conductivity of layer 7, zone 15. Location of zone is shown in figure 16.

${ }^{b}$ Values indicated apply to the same zone number as horizontal hydraulic conductivity and are represented with the prefix vk in the LPF Package.

${ }^{c}$ Values indicated apply to LPF parameters: sy12, sy13, sy14, sy15 and sy23. 
values to support the representation of the conceptual model, including water levels, groundwater discharge to streams, and regional flow budgets.

Calibration of the groundwater-flow model is achieved by a trial-and-error approach. The initial model is evaluated by comparing differences between simulated and observed values, and hydrologic parameters in the model are adjusted until simulated differences are within range of the calibration criteria. Hydrologic properties are adjusted during model calibration to minimize the differences between simulated and measured values of one or more of the following: (1) estimated base flow at 12 streamflow-gaging stations, (2) water levels in 63 selected wells, (3) potentiometric surfaces in October 2003, and (4) water levels in 14 selected observation wells for which long-term hydrographs are available. The goal of the calibration is to simulate the groundwater-flow system so that the general direction and shape of the simulated water table and potentiometric surfaces generally match contoured surfaces derived from water level measurements, and the majority of groundwater-level residuals are within 10 feet. Potentiometric-surface maps of all confined aquifers in the New Jersey Coastal Plain, generated from measurements of groundwater level during October to December 2003 (dePaul and others, 2009), are used in this analysis.

Initial values of specific yield for the unconfined Kirkwood-Cohansey aquifer system (layer 1) and the unconfined part of the Vincentown aquifer are set to published values and adjusted during model calibration by comparing measured water levels at wells screened in the unconfined aquifer to simulated heads in the respective model layer. Storage is a source of water to groundwater-withdrawal wells, and the amount of water available from storage varies from aquifer to aquifer. Hydrographs of simulated and measured water levels are compared for wells screened within each respective aquifer. Initial published values of specific storage are adjusted for each model layer to minimize the difference between simulated heads and periodic water-level measurements at observation or withdrawal wells.

The average difference (simulated water level minus measured water level or residual), average absolute difference, and the root mean square error between simulated and measured water levels at 63 wells that had more than one water-level measurement during January 2000 to December 2003 are used to evaluate model calibration (table 7). Individual water-level measurements are compared to the simulated monthly water level for the stress period in which they occur. The root mean square error for 631 water-level measurements within the study area is 13.0 feet, indicative of a reasonable fit between simulated and measured water levels. Seventy-eight percent of the simulated water levels are within 11 feet of the measured water levels. Wells that had a water-level residual greater than 9 feet include public-supply wells and observation wells near public-supply wells where substantial withdrawals occur. The average of the residual for each aquifer ranges from -13.2 to 6.2 feet. The average absolute difference residual for each aquifer ranges from 4.7 to 13.2 feet.
Average residuals between simulated and measured water levels are within $+/-10$ feet at 20 wells, within $+/-15$ feet at 4 wells, and less than -15 feet at 4 wells of a total of 28 selected wells screened in the Kirkwood-Cohansey aquifer system (table 7). The number of water level measurements at each well ranges from 2 to 24 . The absolute values of the average water-level residuals for wells screened in the Kirkwood-Cohansey aquifer system are 11 feet or less at 23 of 28 wells, and the average of residuals is -4.6 feet (table 7). Negative water-level residuals indicate that the altitude of the simulated water level in a model cell is less (lower) than the measured water level in a well located in the same model cell. Residuals less than -15 feet are noted at several publicsupply wells screened in the Kirkwood-Cohansey aquifer system (well 29-1066, 29-1068, and 29-1095) and observation well 29-1622. Differences between measured and simulated water levels in this area may be due to several factors. Measured water levels are recorded at public-supply wells when the pump in each well is off for a period of time to allow the pumping water level to recover to an altitude that is generally representative of unstressed conditions. The simulated water level in each production well is affected by the simulated quantity of water withdrawn from the well during the stress period. Simulated withdrawals lower the simulated water level in a model cell that contains a production well when a large quantity of water is withdrawn over the duration of the stress period. Negative residuals often occur when simulated water levels affected by withdrawals are compared to nonstressed measured water levels. In addition, the screened intervals of these wells are within layer 5 (well 29-1095) or 7 (well 29-1066, 29-1068, and 29-1622) of the semi-confined zone, updip from the Atlantic City 800 -foot sand (fig. 6C). A low permeability clay layer above the screen zone in the area of these wells may be thin or missing, resulting in local hydrologic connection to the unconfined Kirkwood-Cohansey aquifer system that is not simulated in the model. The October 2003 simulated water table of the Kirkwood-Cohansey aquifer system closely approximates the measured composite water table (fig. 11A).

Three deep wells in the Kirkwood-Cohansey aquifer system, located in Toms River Borough, are screened in model layer 9 (table 7) and within the mapped updip limit of the Piney Point aquifer. Measured water levels in the wells (29-937, 29-1039, and 29-1133) indicate a hydrologic connection with the Kirkwood-Cohansey aquifer system. These wells are identified as withdrawing water from the KirkwoodCohansey aquifer due to thin or inconsistent clays above the screen zone. At these locations, model layers 1 to 9 are interpreted as the Kirkwood-Cohansey aquifer system.

The October 2003 simulated and measured potentiometric surfaces of the Rio Grande water-bearing zone along with the average 2000 to 2003 water-level residuals are based on data from two public-supply wells screened in the aquifer (fig. 11B). Hydrologic data for the Rio Grande water-bearing zone in the Ocean County study area are limited as a result of the minor geographic extent of the water-bearing zone in the 
Table 7. Average differences between simulated water levels and water levels measured from January 2000 to December 2003 in selected wells, Ocean County study area, New Jersey.

[Location of Ocean County study area is shown in figure 1; USGS, U.S. Geological Survey; NJDEP, New Jersey Department of Environmental Protection; --, no data; ft, feet; residual = simulated minus measured; I, irrigation; P, public-supply; U, unused; NA, not applicable]

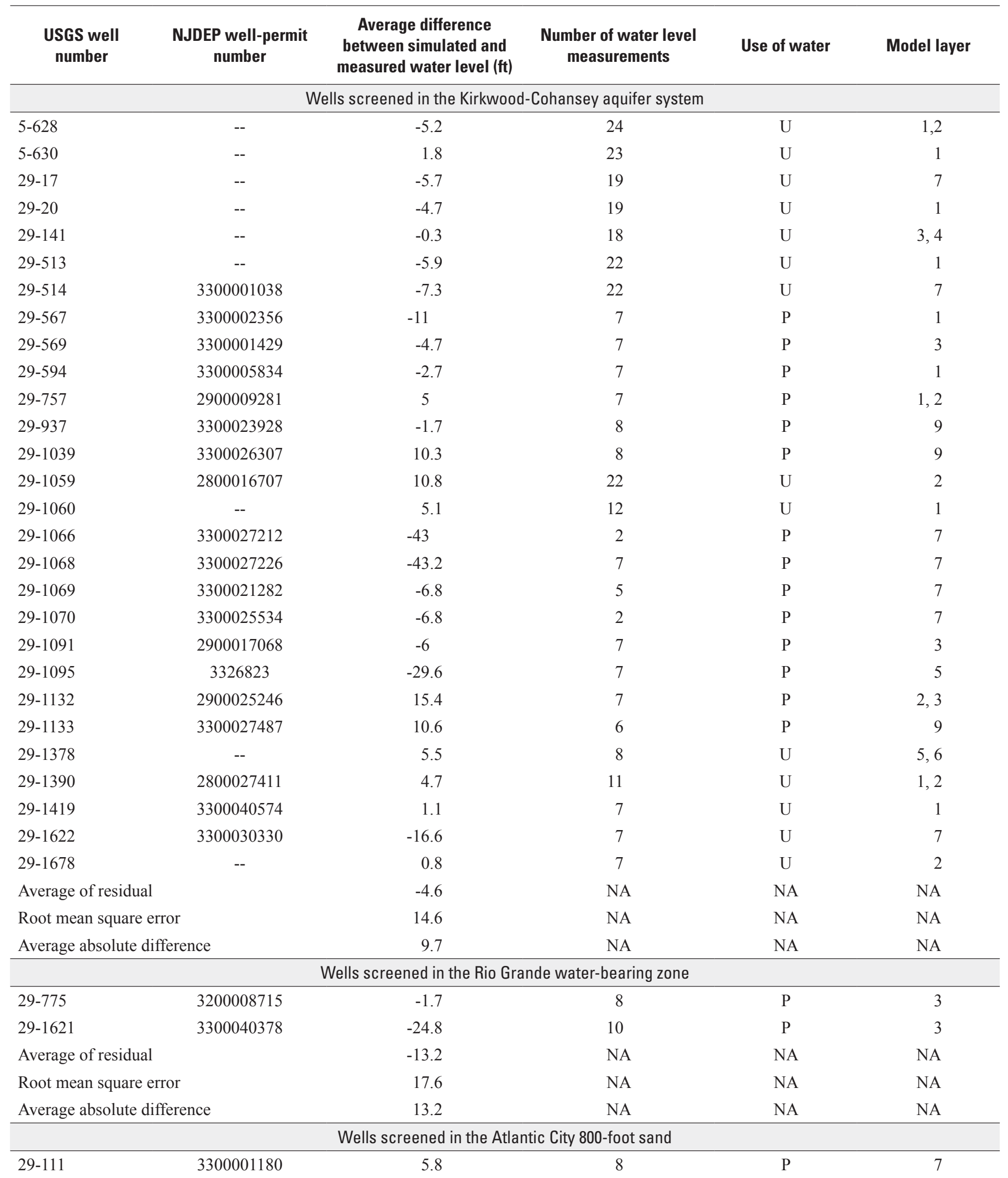


Table 7. Average differences between simulated water levels and water levels measured from January 2000 to December 2003 in selected wells, Ocean County study area, New Jersey.-Continued

[Location of Ocean County study area is shown in figure 1; USGS, U.S. Geological Survey; NJDEP, New Jersey Department of Environmental Protection; --, no data; ft, feet; residual = simulated minus measured; I, irrigation; P, public-supply; U, unused; NA, not applicable]

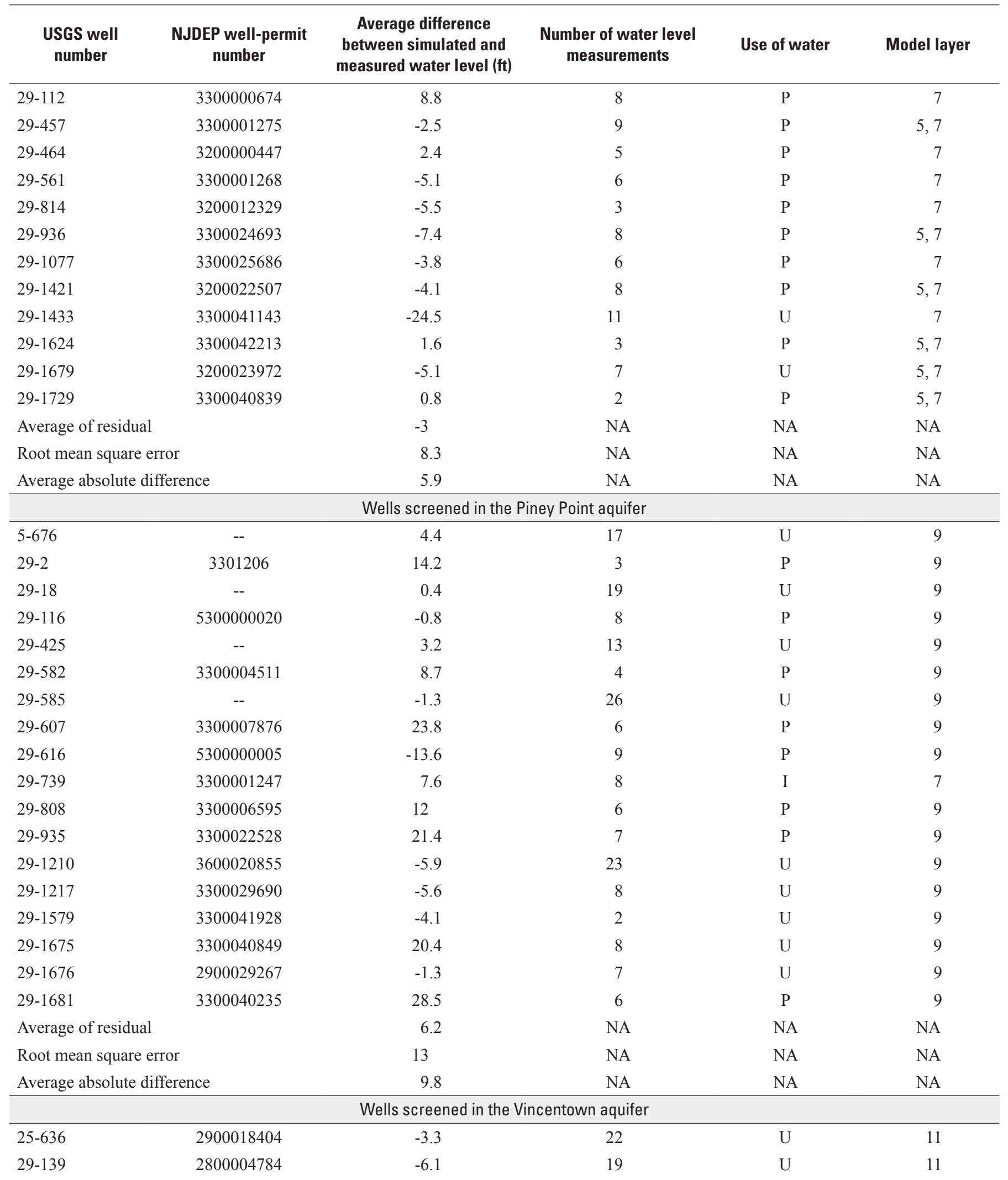


Table 7. Average differences between simulated water levels and water levels measured from January 2000 to December 2003 in selected wells, Ocean County study area, New Jersey.-Continued

[Location of Ocean County study area is shown in figure 1; USGS, U.S. Geological Survey; NJDEP, New Jersey Department of Environmental Protection; --, no data; ft, feet; residual = simulated minus measured; I, irrigation; P, public-supply; U, unused; NA, not applicable]

\begin{tabular}{|c|c|c|c|c|}
\hline $\begin{array}{c}\text { NJDEP well-permit } \\
\text { number }\end{array}$ & $\begin{array}{c}\text { Average difference } \\
\text { between simulated and } \\
\text { measured water level (ft) }\end{array}$ & $\begin{array}{c}\text { Number of water level } \\
\text { measurements }\end{array}$ & Use of water & Model layer \\
\hline Root mean square error & 4.9 & NA & NA & NA \\
\hline Average absolute difference & 4.7 & NA & NA & NA \\
\hline
\end{tabular}

southeastern part of the county. The average residual at the two public-supply wells is -13.2 feet.

The October 2003 simulated potentiometric surface of the upper and lower sands of the Atlantic City 800-foot sand are very similar (figs. $11 C$ and $D$ ). Most of the wells screened in the Atlantic City 800-foot sand are public-supply wells on Long Beach Island and are subject to high withdrawal demand. Measured water levels in these wells are affected by pumping conditions at or near each well. Residuals at 12 of 13 wells are $+/-9$ feet or less (table 7). The average of residuals in the Atlantic City 800 -foot sand is -3 feet. Simulated water levels are within 5 feet of the measured 2003 potentiometric surface near the cone of depression in the southern part of the barrier island.

The October 2003 simulated potentiometric surface closely approximates the measured potentiometric surface of the Piney Point aquifer (fig. 11E). The depths of two cones of depression centered near Barnegat Light Borough and Seaside Park, New Jersey, are accurately simulated. Simulated water levels for 14 of the 18 observation wells screened in the Piney Point aquifer are within $+/-14$ feet of measured water levels (table 7). Average water level residuals are greater than 14 feet at several public-supply wells and at observation well 29-1675. Well 29-1675 with a residual of 20 feet is near observation wells 29-1217 and 29-585 where simulated water levels are within -6 feet of measured water levels.

More emphasis is placed on closely matching measured water levels at 14 selected observation wells (fig. 12) than at public-supply wells during calibration. Simulated water levels at these observation wells screened in the KirkwoodCohansey aquifer system, Rio Grande water-bearing zone, Atlantic City 800-foot sand, and the Piney Point aquifer are within $+/-11$ feet of measured water levels with the exception of well 29-1433, screened in the Atlantic City 800-foot sand aquifer. Well 29-1433 is in close proximity to public-supply wells screened in the same aquifer. Simulated water levels also reflect monthly, seasonal, and long-term trends in measured water levels (fig. 13).

Base flows are estimated for 12 streamflow-gaging stations within the Ocean County study area (fig. 14). Five streamflow-gaging stations are equipped with instrumentation that records continuous streamflow, and seven streamflow-gaging stations are sites at which periodic streamflow measurements are made during low-flow conditions. Base flow estimates from streamflow measurements at continuous record stations are based on hydrograph separation methods described by Rutledge (1993). Base flow estimates for periodic-record stations are based on developing correlations with index stations and using the estimated base flow for the index station in the correlation equation.

Calibration to monthly base flow is achieved by varying values of model parameters within a plausible range to achieve a reasonable match in base flow while not adversely affecting simulated groundwater levels in the unconfined part of the groundwater-flow model. Model parameters that were adjusted include streambed conductance, horizontal and vertical conductivity of model layers 1 and 2, and specific yield. Recharge rates were changed during calibration by modifying the recharge multiplier, thereby keeping the areal variability based on the NJGWS recharge data.

Streamflow-gaging stations are used as calibration points because measured streamflow is from distinct areas of the Barnegat Bay-Little Egg Harbor watershed or other subbasins in the study area. Base-flow separations and low-flow correlations are used to estimate average monthly base flow over a 48-month period (January 2000 to December 2003) at 5 continuous-record stations and 7 low-flow partial-record stations (table 8). Simulated base flow values are calculated by summing the flow to drain cells (used to represent wetlands adjacent to stream reaches) and the flow to river cells upstream from each streamflow-gaging station location in the model (fig. 15). The intent of the calibration is to minimize differences in trends between simulated and estimated mean monthly base flows with relatively small residuals. Simulated monthly base flow is compared to estimated mean monthly base flow for the 48 monthly stress periods, 42 through 84 , representing 2000 through 2003 transient conditions. In general, monthly simulated base flows evaluated at the 12 streamflow-gaging stations match the estimated base flows fairly well. The simulated and estimated hydrographs have 

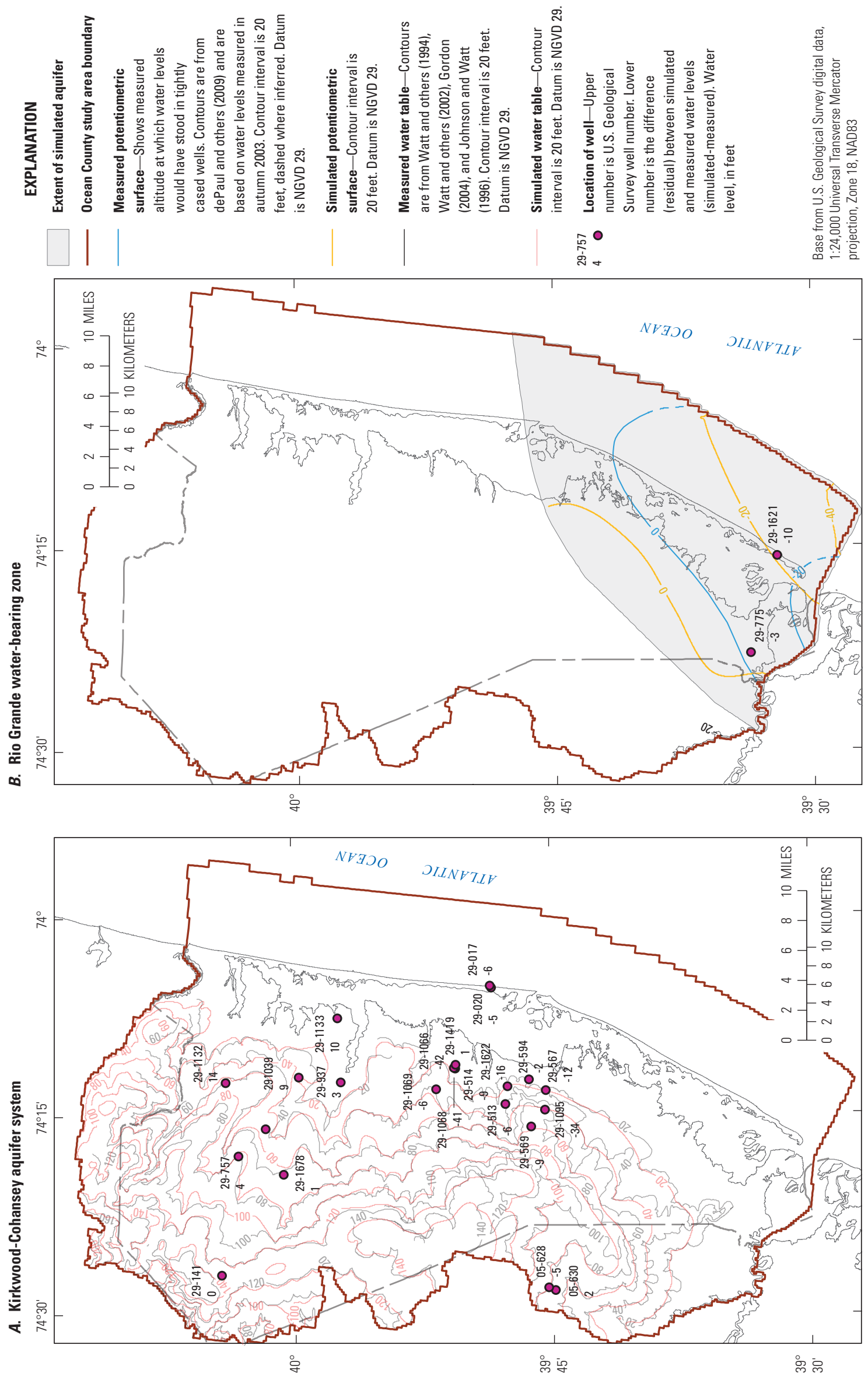

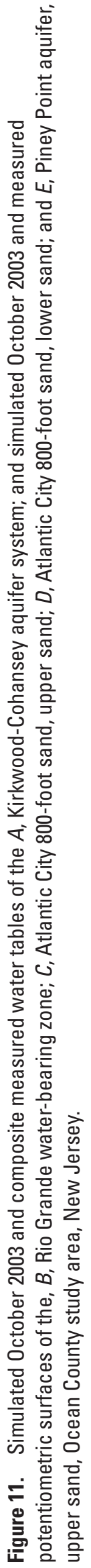



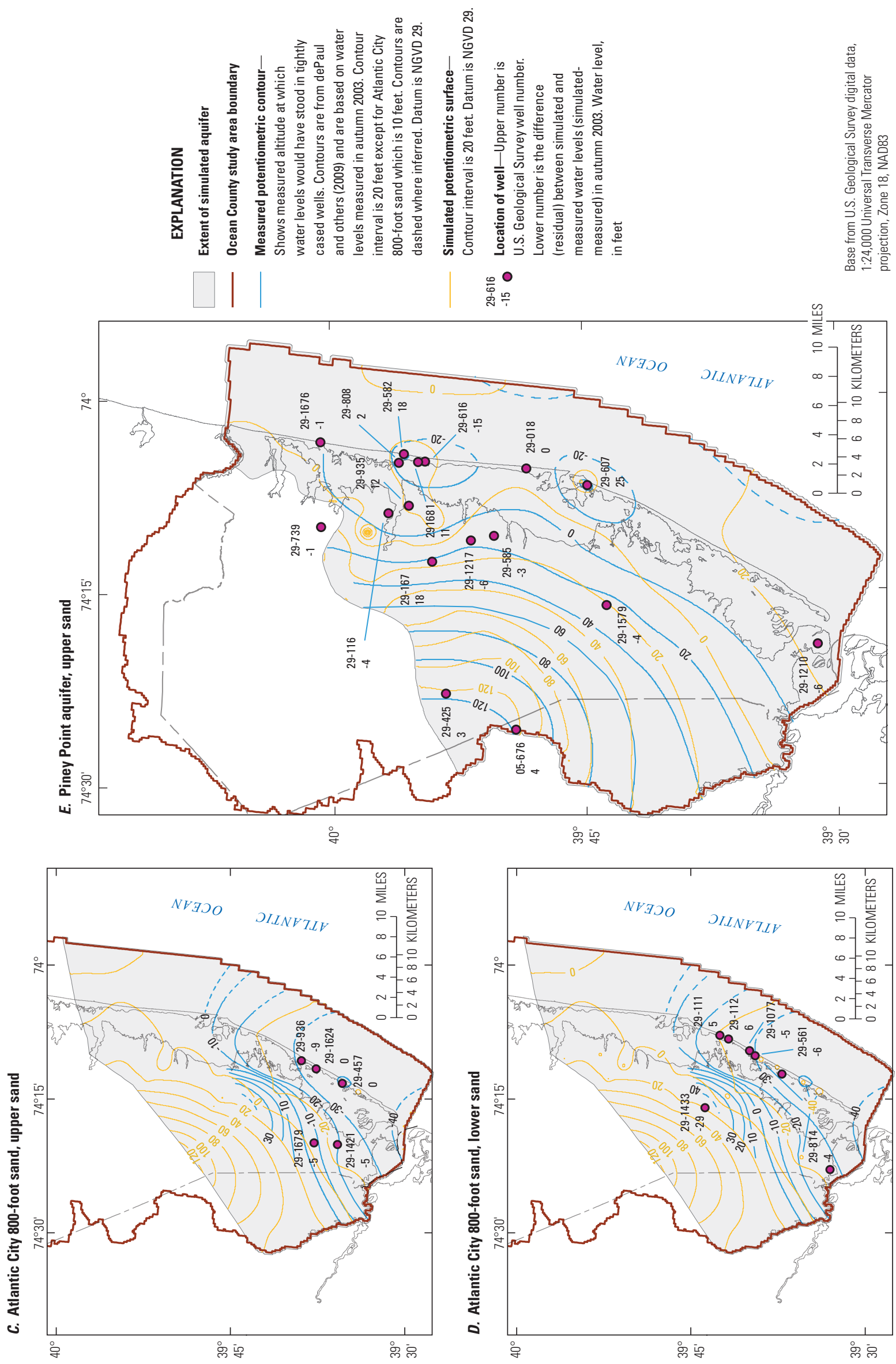

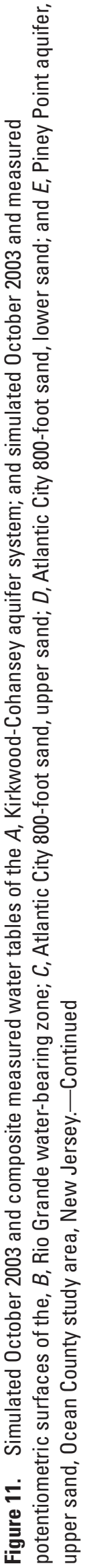




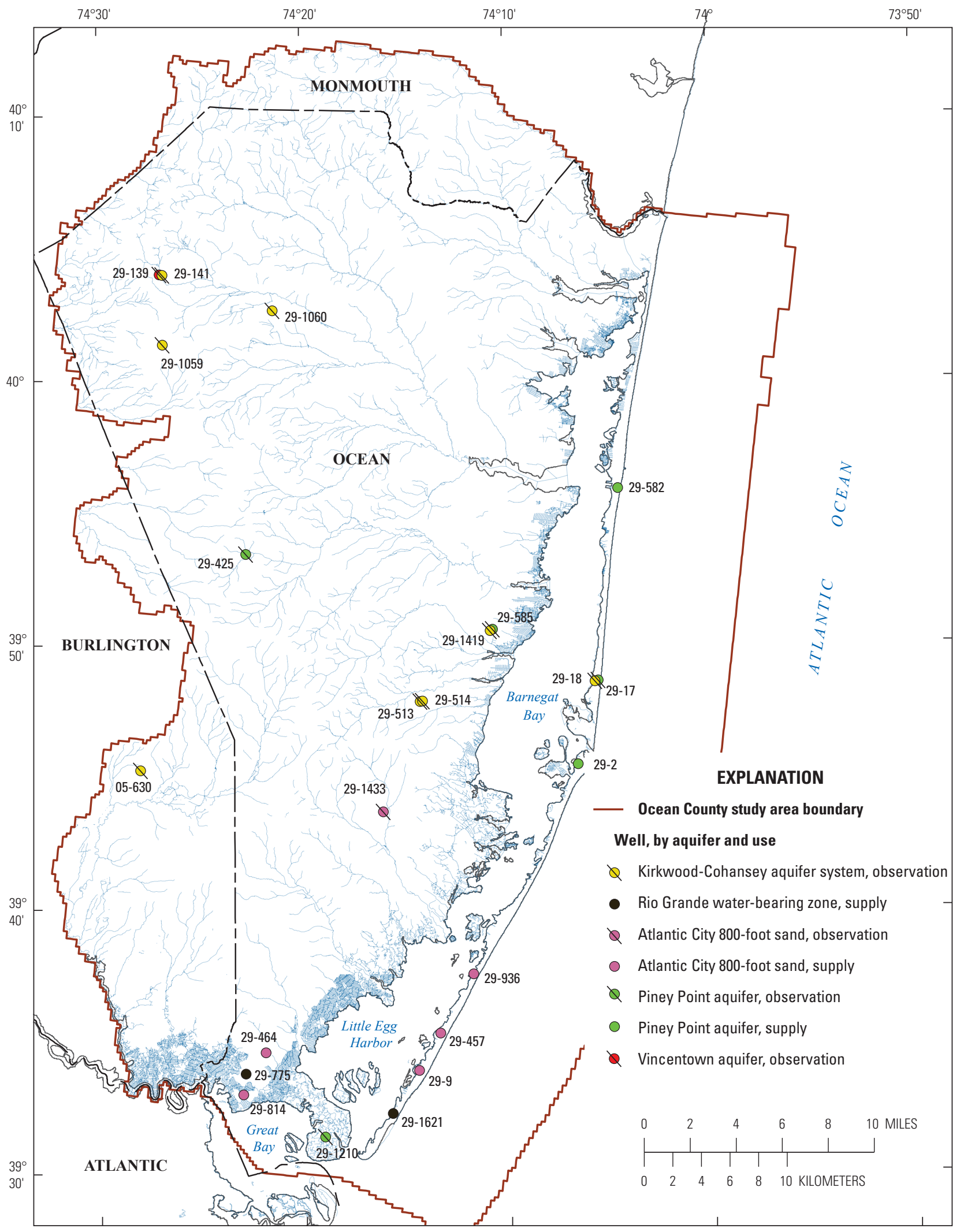

Base from U.S. Geological Survey digital data, 1:24,000

Universal Transverse Mercator projection, Zone 18, NAD83

Figure 12. Location of selected hydrograph wells with periodic water-level measurements, Ocean County study area, New Jersey. 
A. Kirkwood-Cohansey aquifer system; column 45 , row 218 , layer 1 , well 5-630

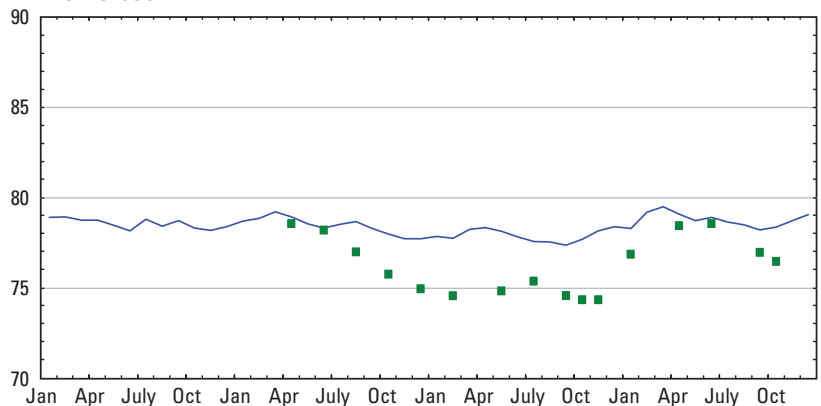

C. Kirkwood-Cohansey aquifer system; column 123, row 190, layer 1 , well 29-513

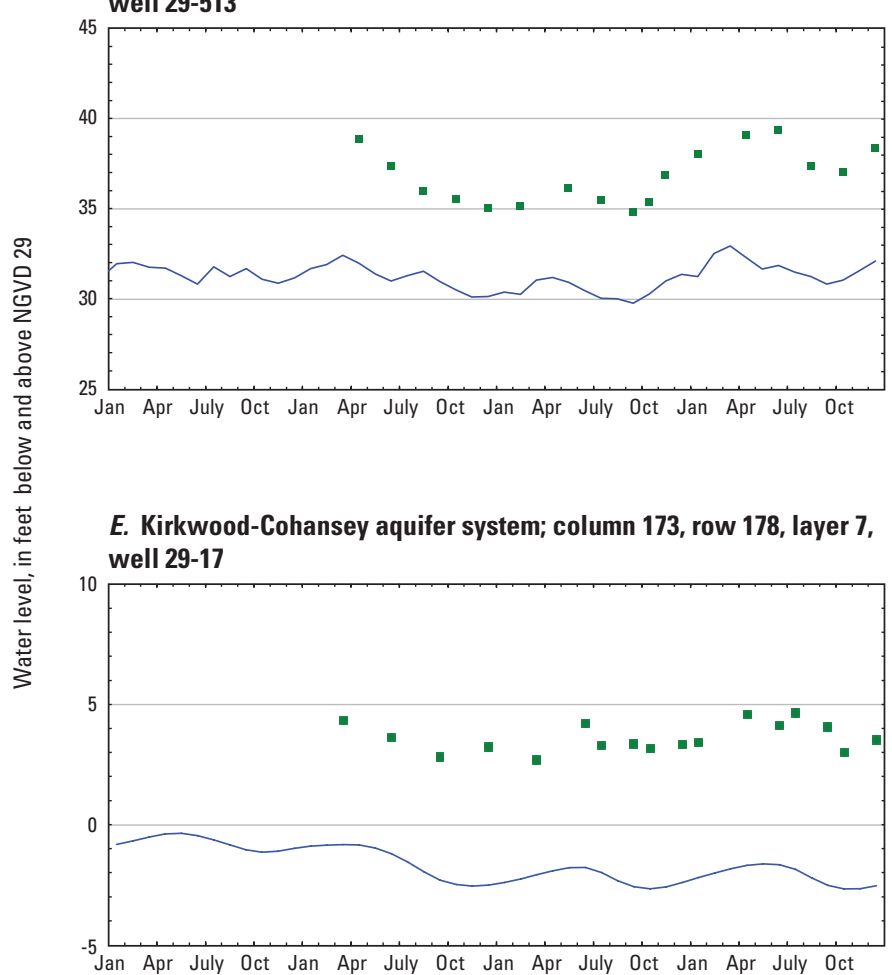

B. Kirkwood-Cohansey aquifer system; column 36 , row 74 , layer 3 , well 29-141

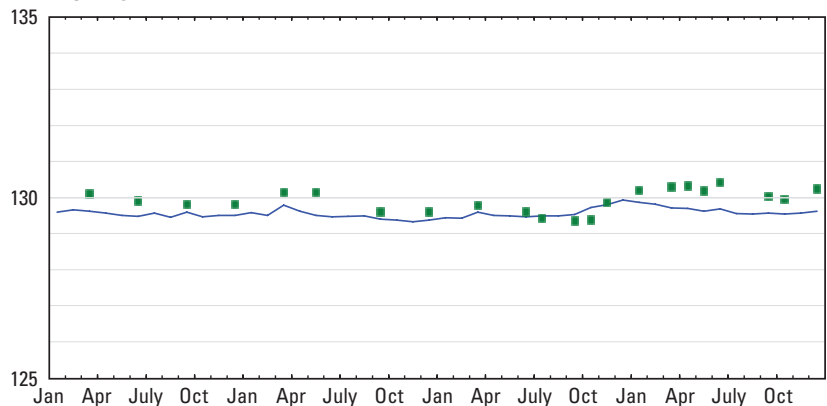

D. Kirkwood-Cohansey aquifer system; column 69 , row 82 , layer 1 , well 29-1060

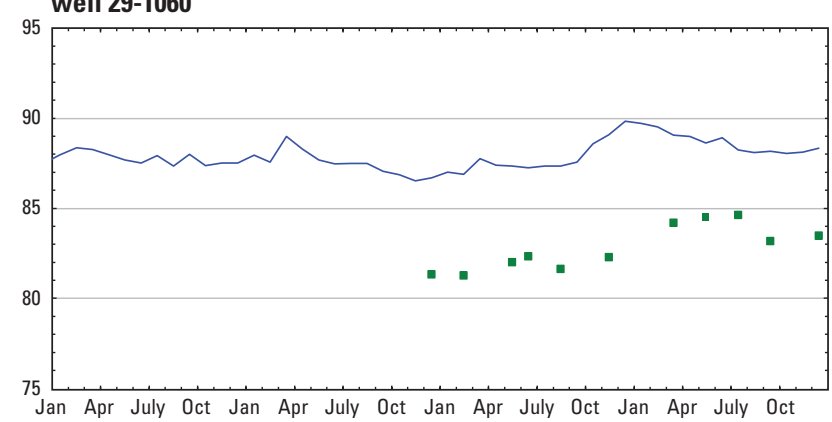

F. Kirkwood-Cohansey aquifer system; column 123, row 190, layer 7 , well 29-514

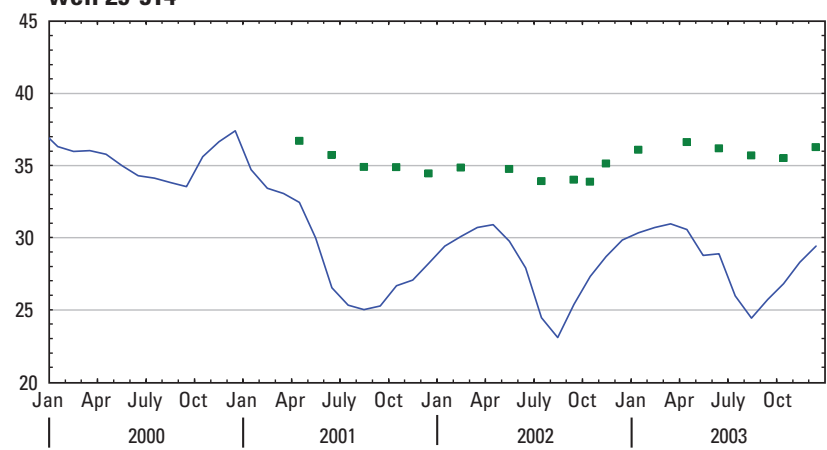

G. Rio Grande water-bearing zone; column 84 , row 302 , layer 3 , well 29-775

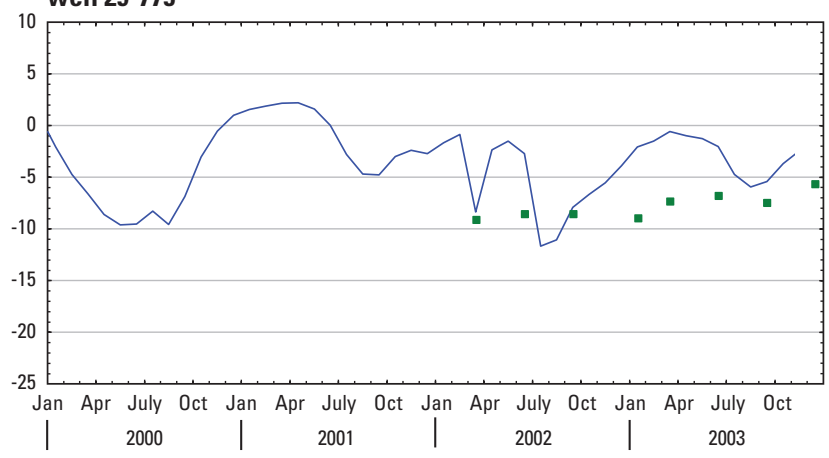

EXPLANATION

- Simulated water level

- Measured water level

Figure 13. Hydrographs of simulated and measured water levels at selected wells screened in: $A$ to $F$, the Kirkwood Cohansey aquifer system; $G$ to $H$, Rio Grande water-bearing zone; / to $K$, Atlantic City 800 -foot sand; and; $L$ to $N$, Piney Point aquifer, 0 cean County study area, New Jersey, 2000 to 2003. 
H. Rio Grande water-bearing zone; column 128, row 309, layer 3, well 29-1621

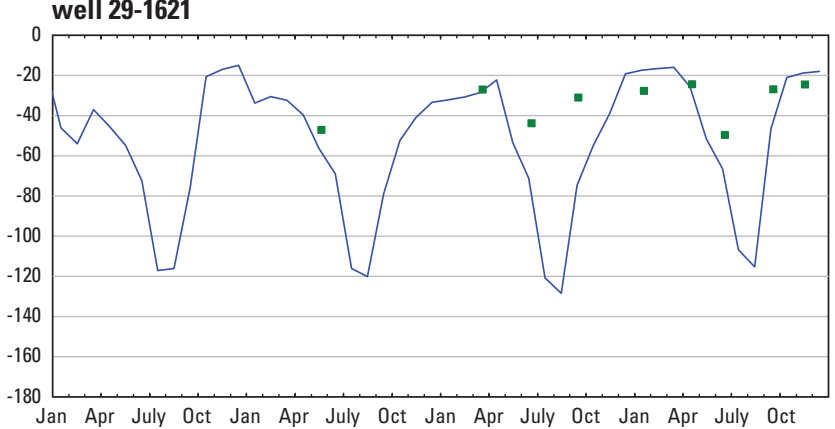

J. Atlantic City 800-foot sand; column 147, row 266, layer 5 and 7, well 29-936

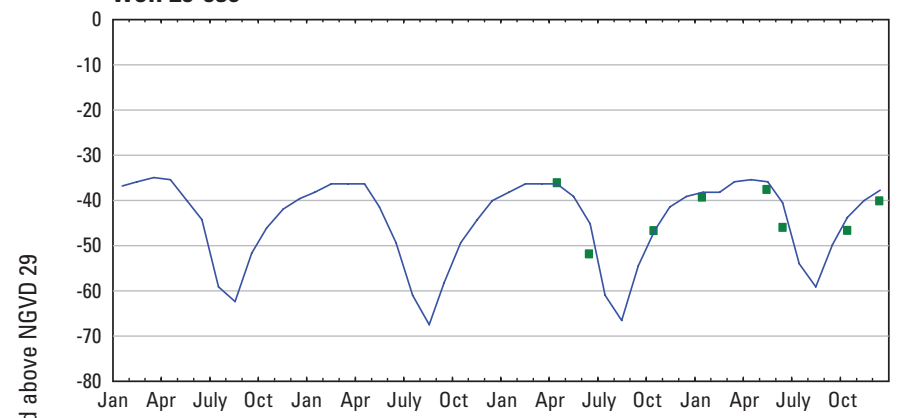

L. Piney Point aquifer; column 69, row 153, layer 9, well 29-425

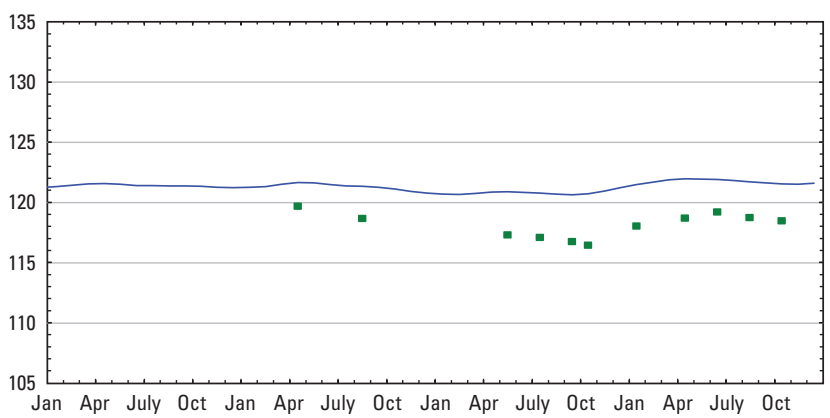

N. Piney Point aquifer; column 109, row 317, layer 9, well 29-1210

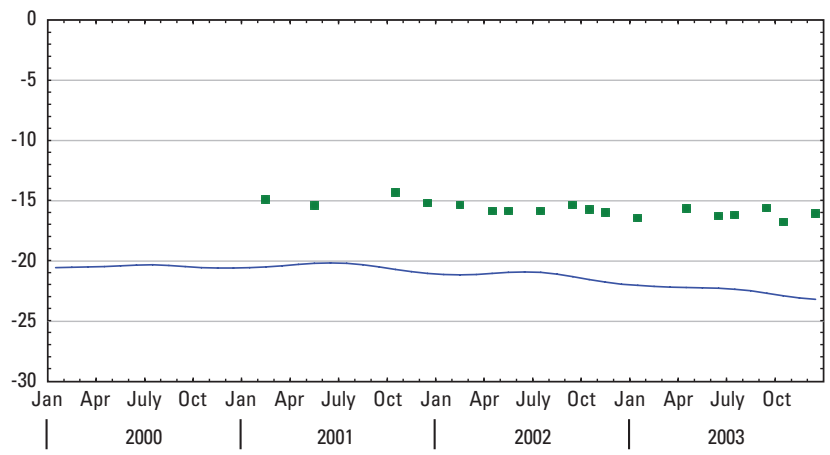

I. Atlantic City 800-foot sand; column 139, row 2854, layer 5 and 7, well 29-457

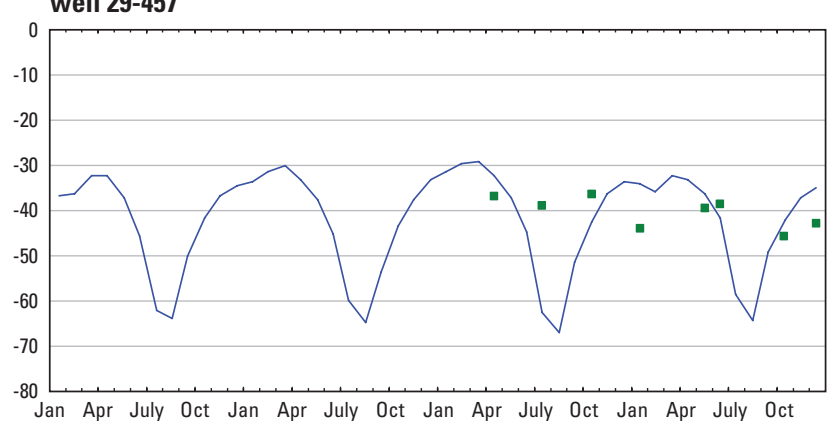

K. Atlantic City 800 -foot sand; column 89 , row 295 , layer 7 , well 29-464

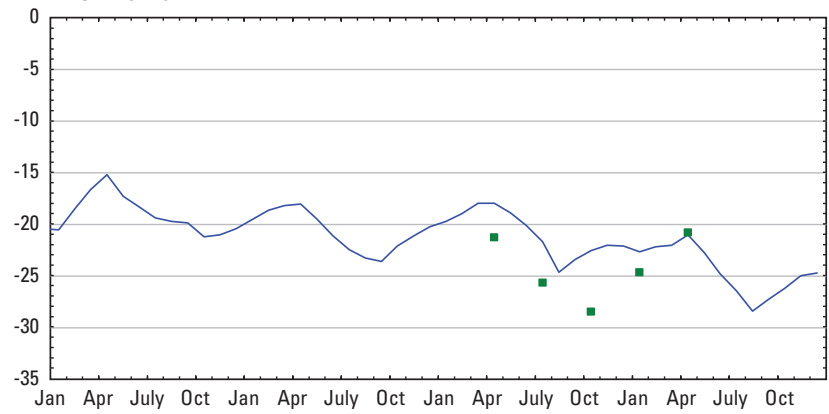

M. Piney Point aquifer; column 142, row 167, layer 9, well 29-585

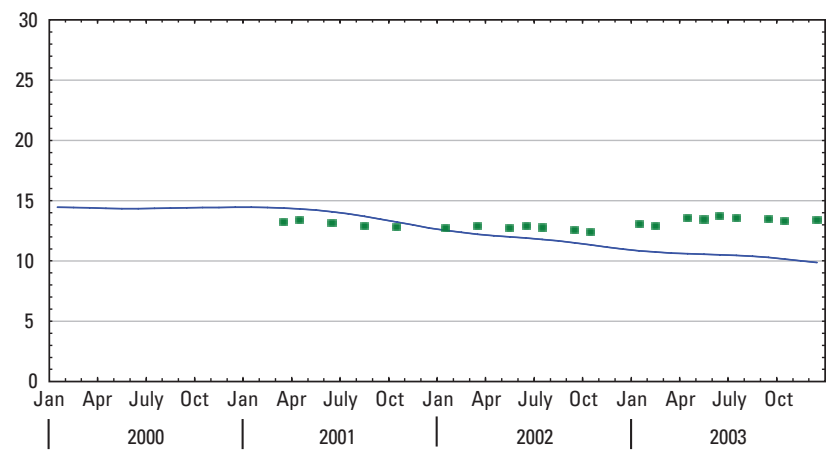

Figure 13. Hydrographs of simulated and measured water levels at selected wells screened in: $A$ to $F$, the Kirkwood Cohansey aquifer system; $G$ to $H$, Rio Grande water-bearing zone; I to $K$, Atlantic City 800 -foot sand; and; $L$ to $N$, Piney Point aquifer, 0 cean County study area, New Jersey, 2000 to 2003.-Continued 


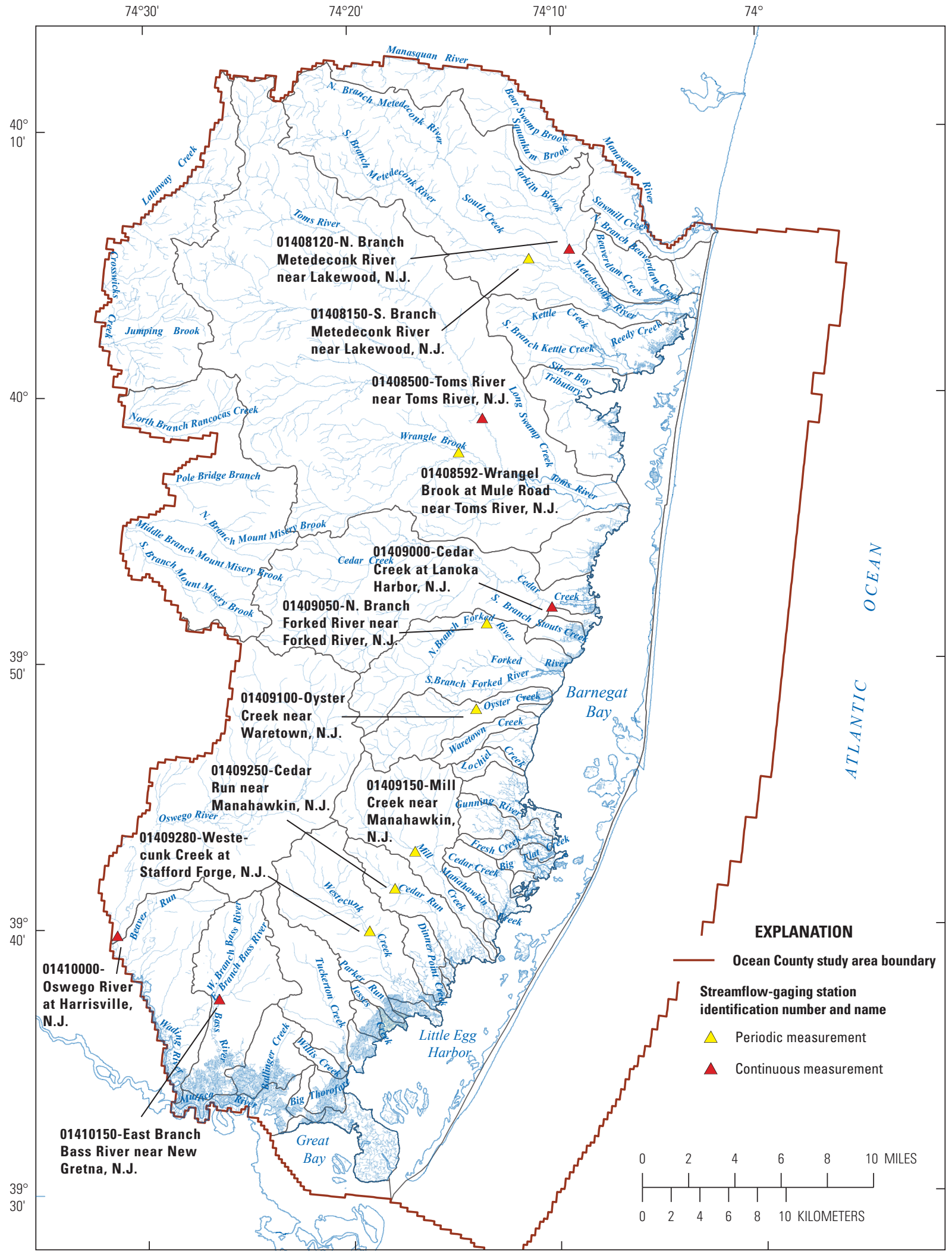

Base from U.S. Geological Survey digital data, 1:24,000

Universal Transverse Mercator projection, Zone 18, NAD83

Figure 14. Location of selected streamflow-gaging stations in the 0cean County study area, New Jersey. 
Table 8. Simulated and estimated mean monthly base flow at selected streamflow-gaging stations, 0 cean County study area, New Jersey, January 2000 to December 2003.

[Location of Ocean County study area is shown in figure 1; USGS, U.S. Geological Survey; HS, hydrograph separation; LFC, low-flow correlation; ft³/s, cubic feet per second]

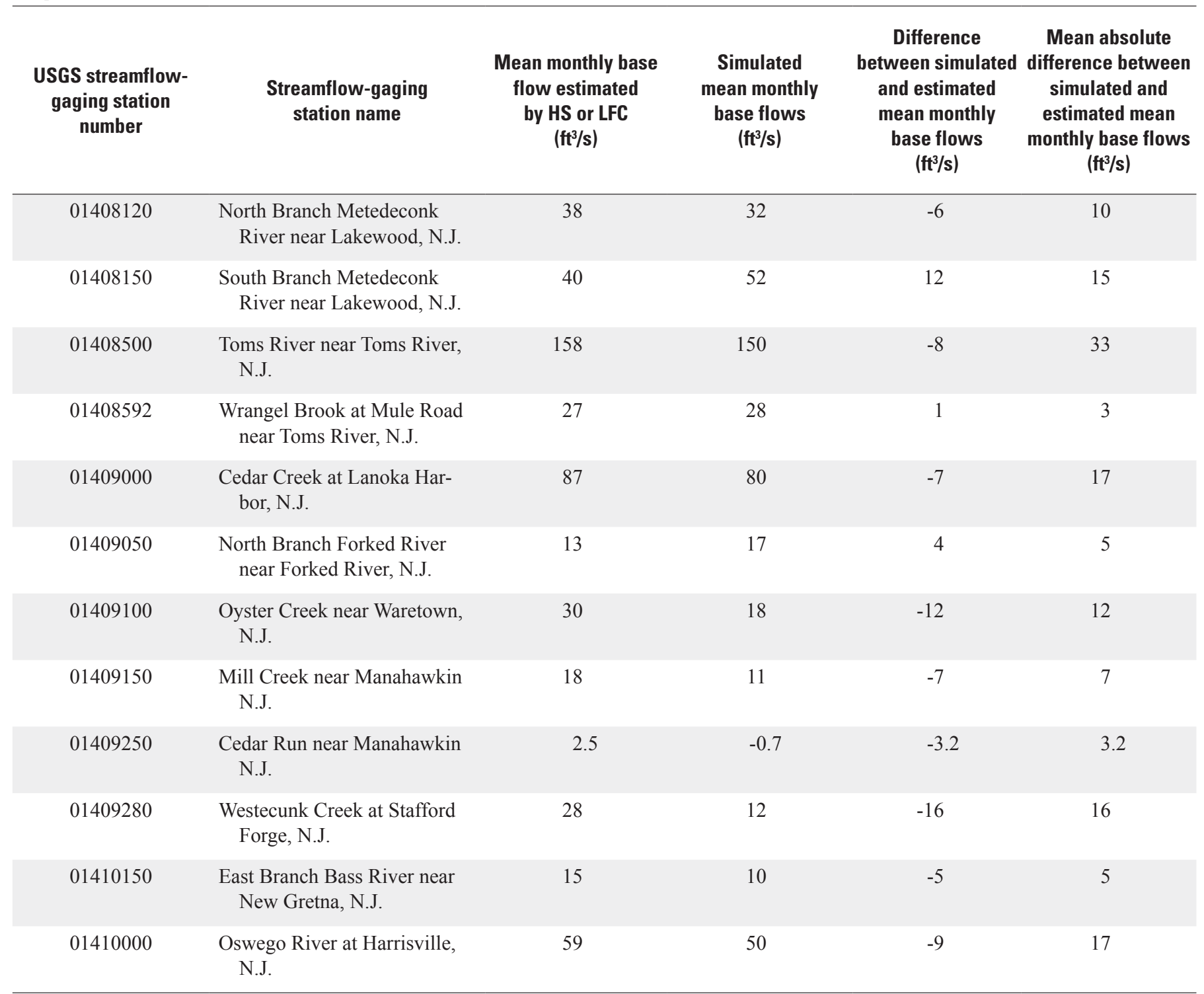

fairly good correspondence at continuous-record streamflowgaging stations, and the mean absolute difference between simulated and estimated mean monthly base flows are moderate to small (table 8). More emphasis in the calibration is placed on simulating base flow that follows the same temporal pattern as estimated base flow at continuous-record streamflow-gaging stations than at partial-record streamflow-gaging stations. Residual values indicate a reasonable match between simulated and estimated base flow at all streamflow-gaging stations (table 8).

During certain months simulated base-flow peaks are lower than estimated peaks, and simulated lows are higher than estimated lows at certain streamflow-gaging stations (fig. 15). The mean difference and mean absolute difference between simulated and estimated mean monthly base flows are generally small when compared with mean monthly base flows at each streamflow-gaging station. Larger differences between simulated and estimated mean monthly base flows occur at 01409250 Cedar Run (location shown on fig. 14 and base flow on fig. 15I) near Manahawkin, N.J., where flow is from a small drainage area above the gage (3.34 $\left.\mathrm{mi}^{2}\right)$. Comparing mean differences between simulated and estimated base flows indicates that simulated base flows are underestimated in the southern portion of the Ocean County study area at partialrecord streamflow-gaging stations (Oyster Creek Basin to Westecunk Creek Basin). Precipitation and estimated recharge during 1998 and 1999 is greater than 2000, and preliminary model development that simulated 1998 through 2003 

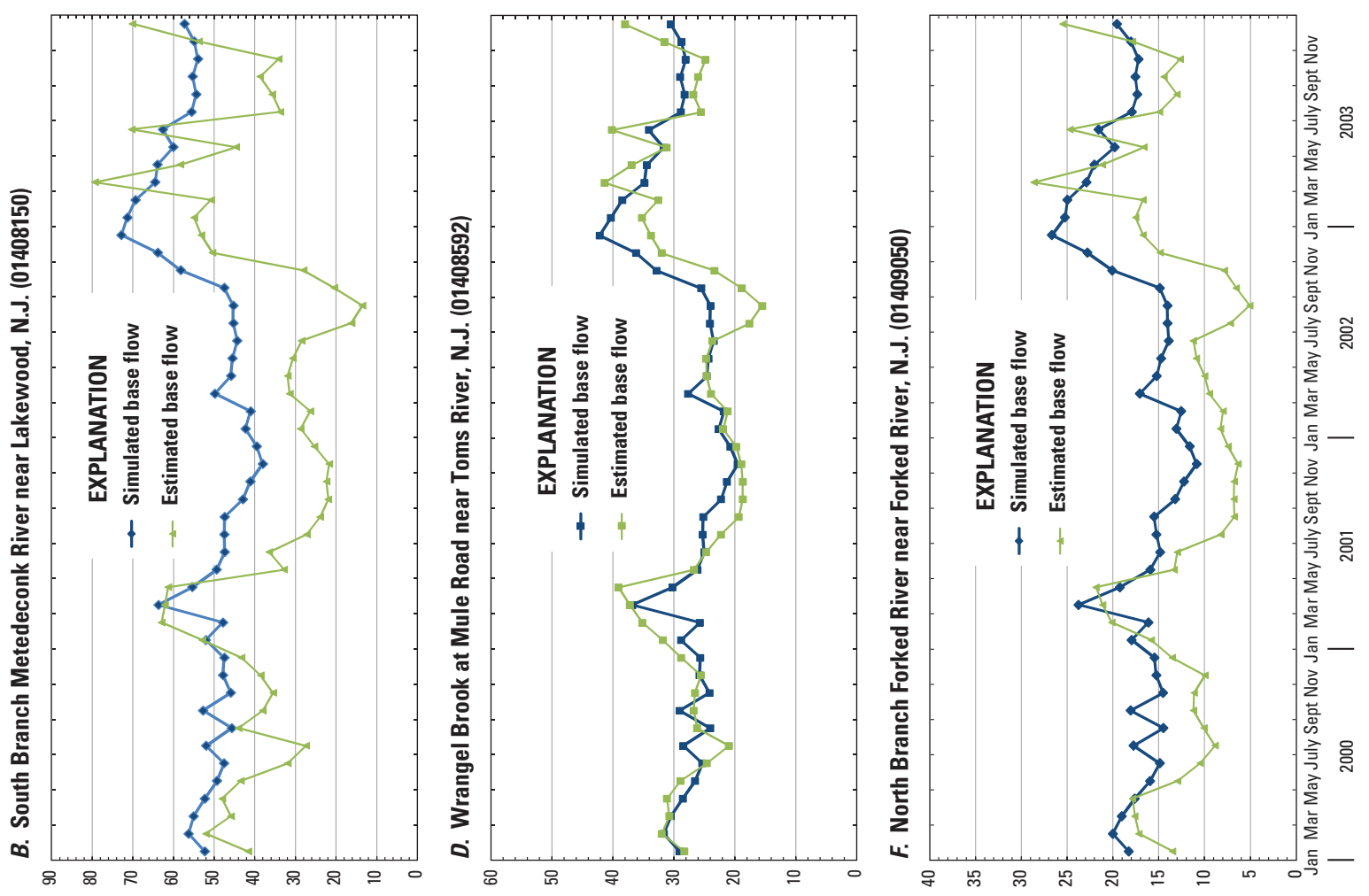

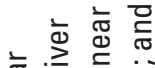

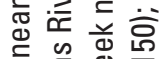

히의 응

我衮可

ป

造容

这等家

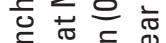

匹는

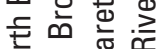

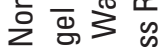

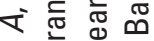

is 3

음 0 ब

元行

.

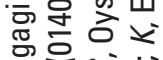

们

을 융 宂

巡氙守守

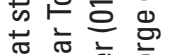

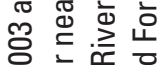

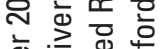

这空恋
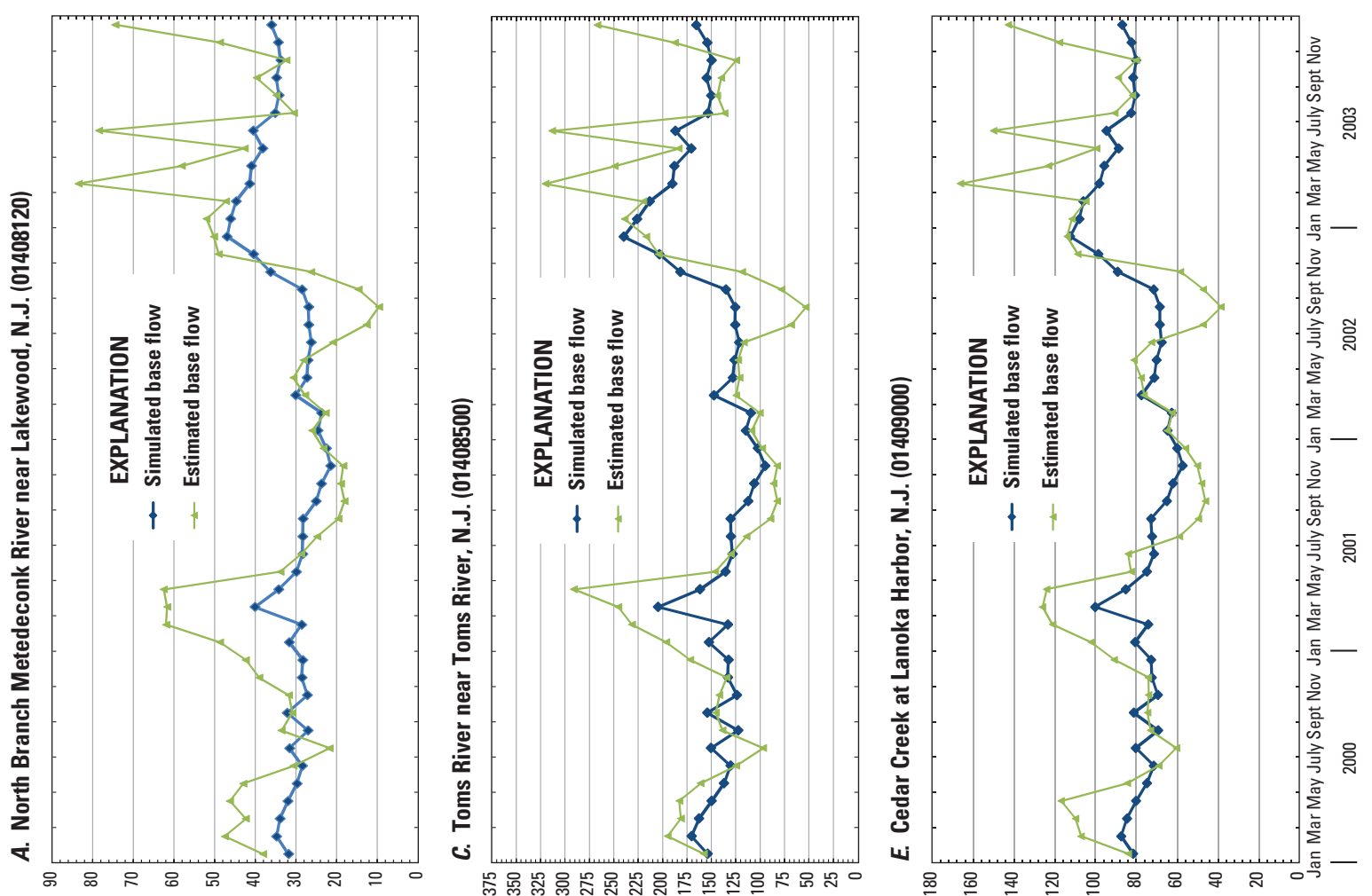

过 흐휴

心品

우원

응 웅 웅

文它离

啶

空它

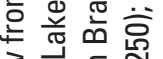

З 츙 융

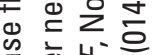

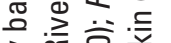

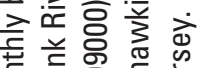

등워

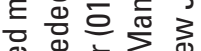

过

站递

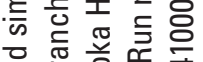

ฮั

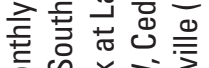

क क ㄴ..에

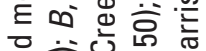

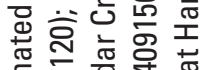

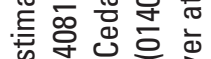

可山腙空

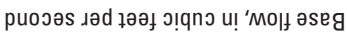

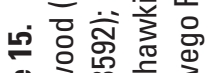

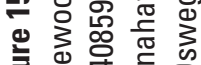



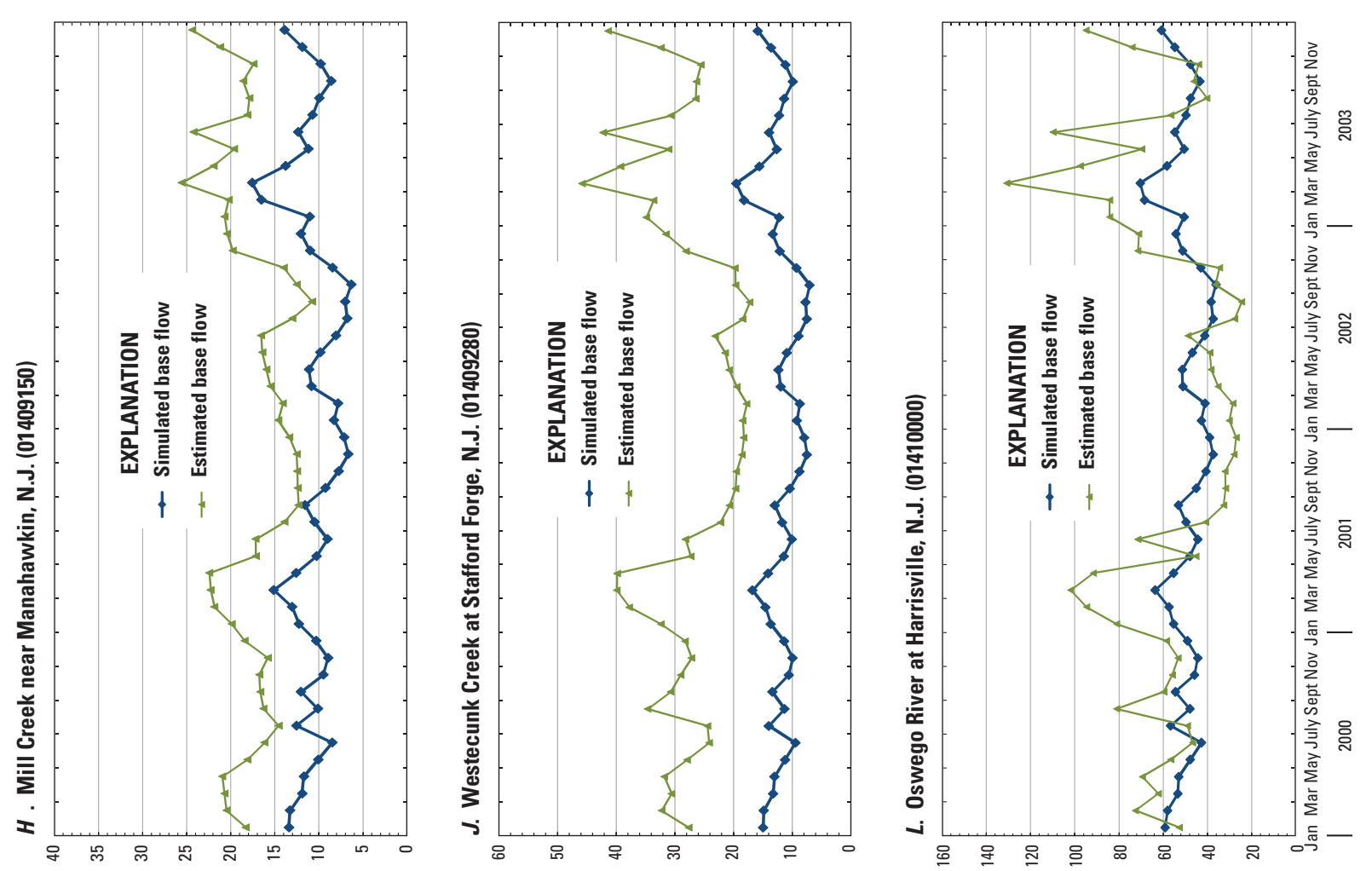

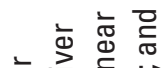

ब西

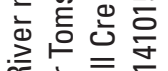

还京要要

言无尔

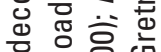

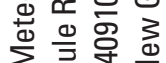

등 $z$

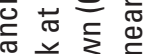

ॠ흥

튼

이요

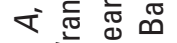

is 3 过

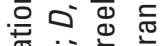

芯市凹

미용

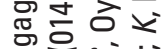

㐫心㐫

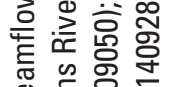

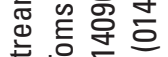

훙으은

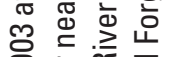

온
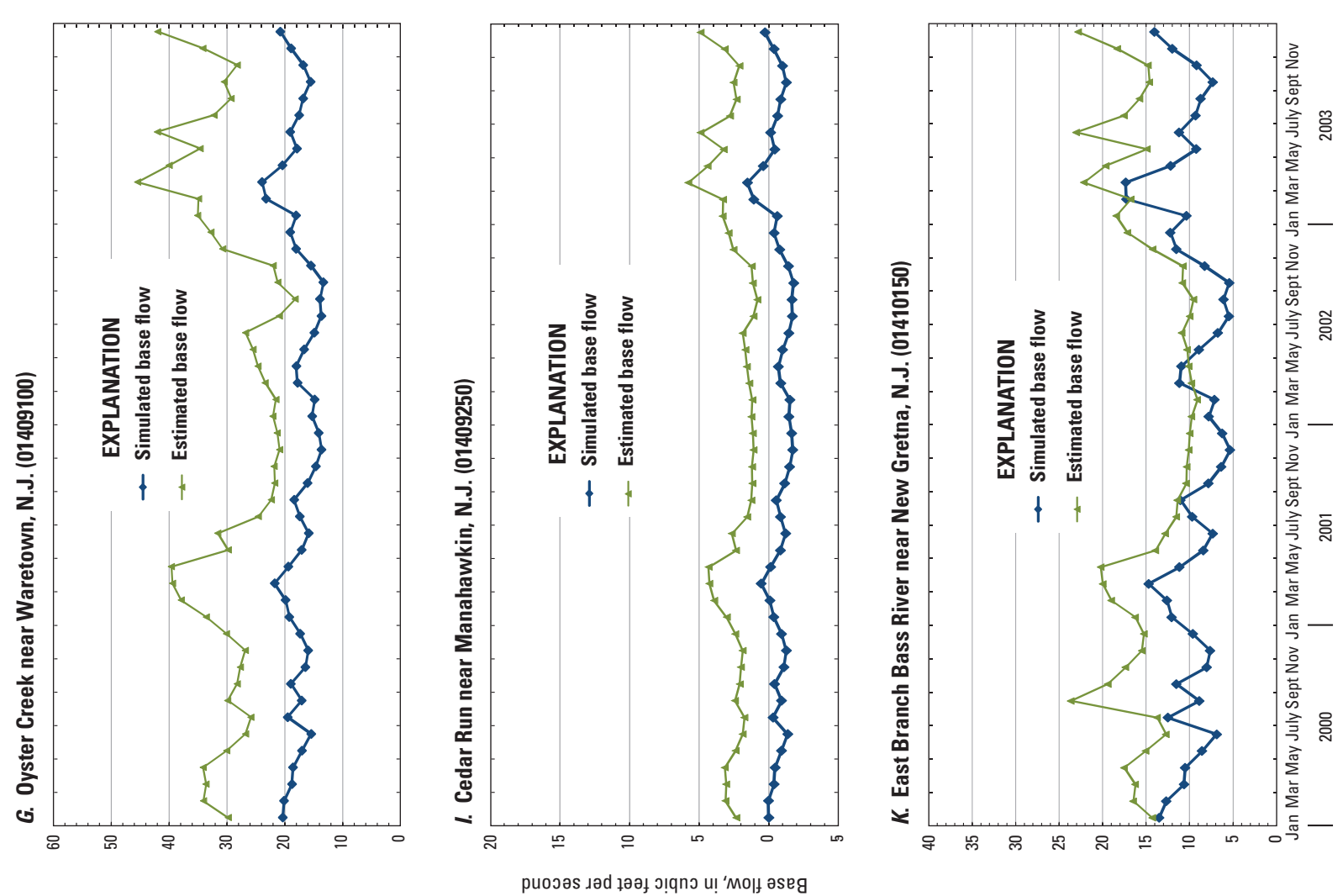

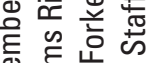

ه

吃 离

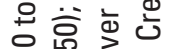

웅ㅎㅇ 웅

궁

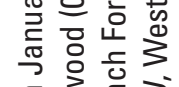

E

亲芯容。

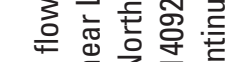

\&

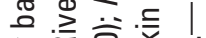

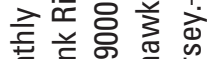

등 웡

동 흐

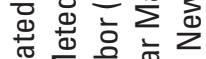

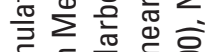

틍 도응

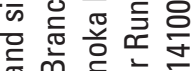

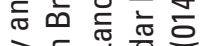

入े 들 寻

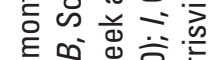

ह 00 过容

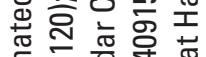

意哭

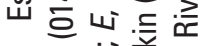

서 홍 离

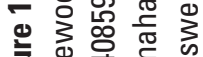

늘 
demonstrated higher simulated monthly base flow during 2000 when the transient simulation included those years. Increasing the recharge multiplier in the southern portion of the Ocean County study area would increase base flow in these streams; however, emphasis in the calibration is placed upon simulating reasonable yearly recharge rates (table 9).

\section{Sensitivity Analysis}

The model calibration demonstrates that the groundwaterflow model defined by its combination of boundary conditions, boundary flows and heads, hydrologic unit definition, geometry, and hydraulic parameters reasonably reproduces the measured water table, base flows, and potentiometric surfaces of the aquifer system for the Ocean County study area. The purpose of sensitivity analysis is to quantify the uncertainty in the calibrated model due to uncertainty in the estimates of aquifer parameters, stresses, and boundary conditions (Anderson and Woessner, 1991). The objective is to determine how readily and excessively water-level altitudes are affected by a change in hydrologic parameters in the calibrated model. A sensitivity analysis of parameters in the groundwater-flow model is computed by using UCODE-2005 (Poeter and others, 2005).

Composite scaled sensitivities (CSS) summarize all the sensitivities for each parameter and are used to evaluate the relative sensitivity of the simulated model parameters (Hill and Tiedeman, 2007). Parameters with large CSS compared to those of other parameters indicate that simulation results are more sensitive to those parameters, given the observations used in this model. CSS are calculated for 115 parameters as part of the model sensitivity analysis (table 10, back of report). The extent of each parameter is delineated according to geologic and hydrogeologic features (fig. 16). Table 10 presents the CSS for each parameter zone and describes the composition of each hydrogeologic unit.

In order to account for imprecision in observations, a weighting factor for observation values is used in the calculation of the CSS. Errors that contribute to the uncertainty of water-level observations are potential inaccuracies in the altitude and location of a well, measurement of a water level, and fluctuations introduced by variations in climate or any other nonsimulated transient stress (Belcher, 2004). The equations

Table 9. Time period, groundwater-withdrawal rate, groundwater discharge to streams, and recharge rate simulated in the groundwater-flow model, Ocean County study area, New Jersey.

[Location of Ocean County study area is shown in figure $1 ; *$, steady-state: **, average inches per year for stress period]

\begin{tabular}{|c|c|c|c|c|c|}
\hline \multirow[b]{2}{*}{ Time period } & \multicolumn{2}{|c|}{ Groundwater-withdrawal rate } & \multirow{2}{*}{$\begin{array}{l}\text { Groundwater } \\
\text { discharge to } \\
\text { streams (cubic } \\
\text { feet per second) }\end{array}$} & \multicolumn{2}{|c|}{ Simulated recharge rate } \\
\hline & $\begin{array}{l}\text { Cubic feet } \\
\text { per second }\end{array}$ & $\begin{array}{l}\text { Million gallons } \\
\text { per day }\end{array}$ & & $\begin{array}{l}\text { Inches } \\
\text { per month }\end{array}$ & $\begin{array}{l}\text { Cubic feet } \\
\text { per second }\end{array}$ \\
\hline January 2000 to December $2000 *$ & 53 & 34 & 709 & $16^{* *}$ & 880 \\
\hline January 2000 & 45 & 29 & 788 & 2.6 & 1,751 \\
\hline March 2000 & 41 & 26 & 791 & 1.3 & 856 \\
\hline April 2000 & 48 & 31 & 742 & 1.0 & 665 \\
\hline May 2000 & 60 & 39 & 670 & 0.5 & 356 \\
\hline June 2000 & 67 & 43 & 620 & 0.5 & 315 \\
\hline September 2000 & 55 & 36 & 765 & 2.5 & 1,673 \\
\hline October 2000 & 47 & 31 & 610 & 0 & 0 \\
\hline November 2000 & 42 & 27 & 638 & 1.1 & 759 \\
\hline December 2000 & 43 & 28 & 656 & 1.4 & 918 \\
\hline January 2001 & 51 & 33 & 761 & 2.3 & 1,560 \\
\hline February 2001 & 48 & 31 & 701 & 1.0 & 690 \\
\hline March 2001 & 51 & 33 & 989 & 4.1 & 2,720 \\
\hline
\end{tabular}


Table 9. Time period, groundwater-withdrawal rate, groundwater discharge to streams, and recharge rate simulated in the groundwater-flow model, Ocean County study area, New Jersey.-Continued

[Location of Ocean County study area is shown in figure $1 ; *$, steady-state: **, average inches per year for stress period]

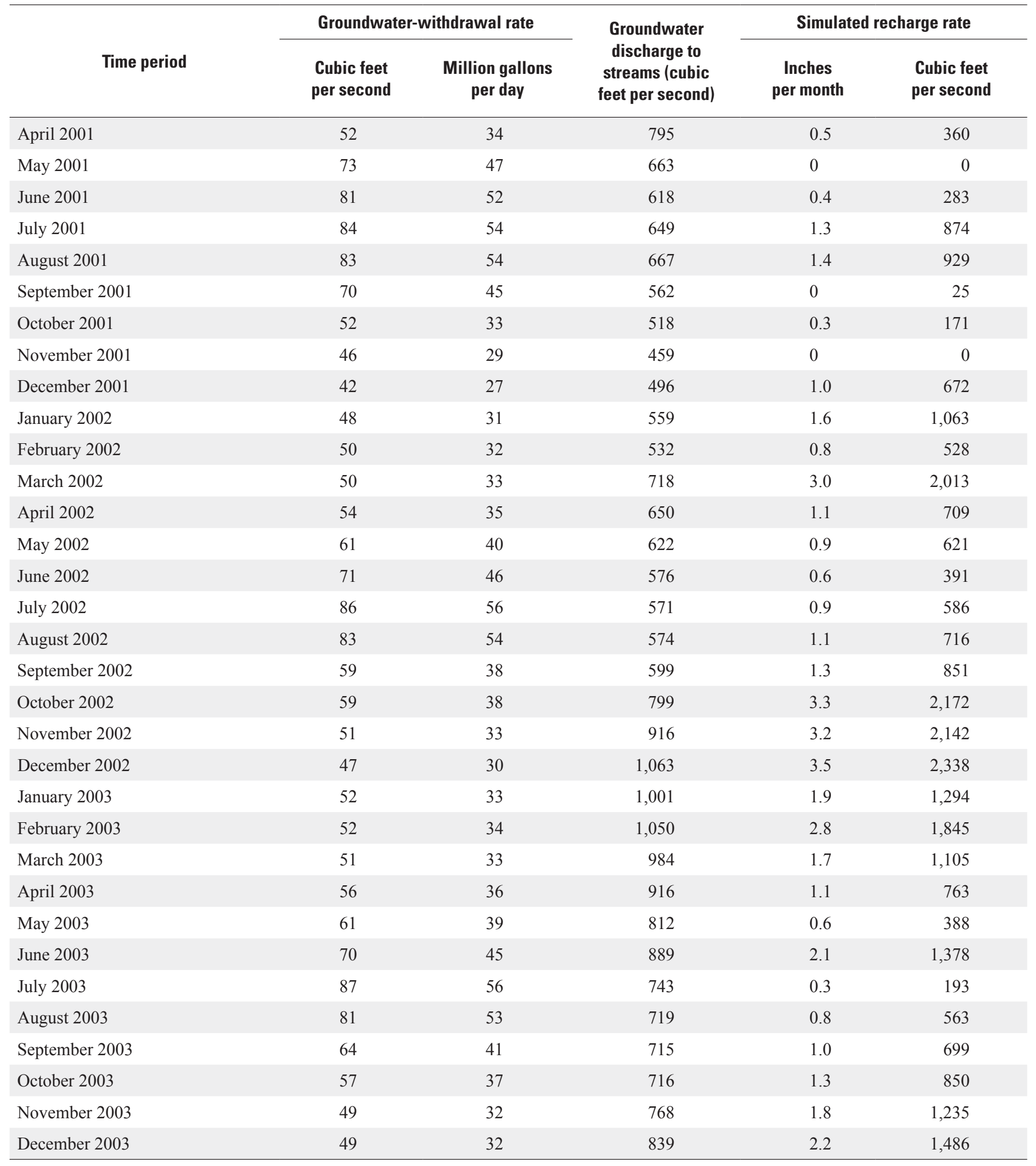



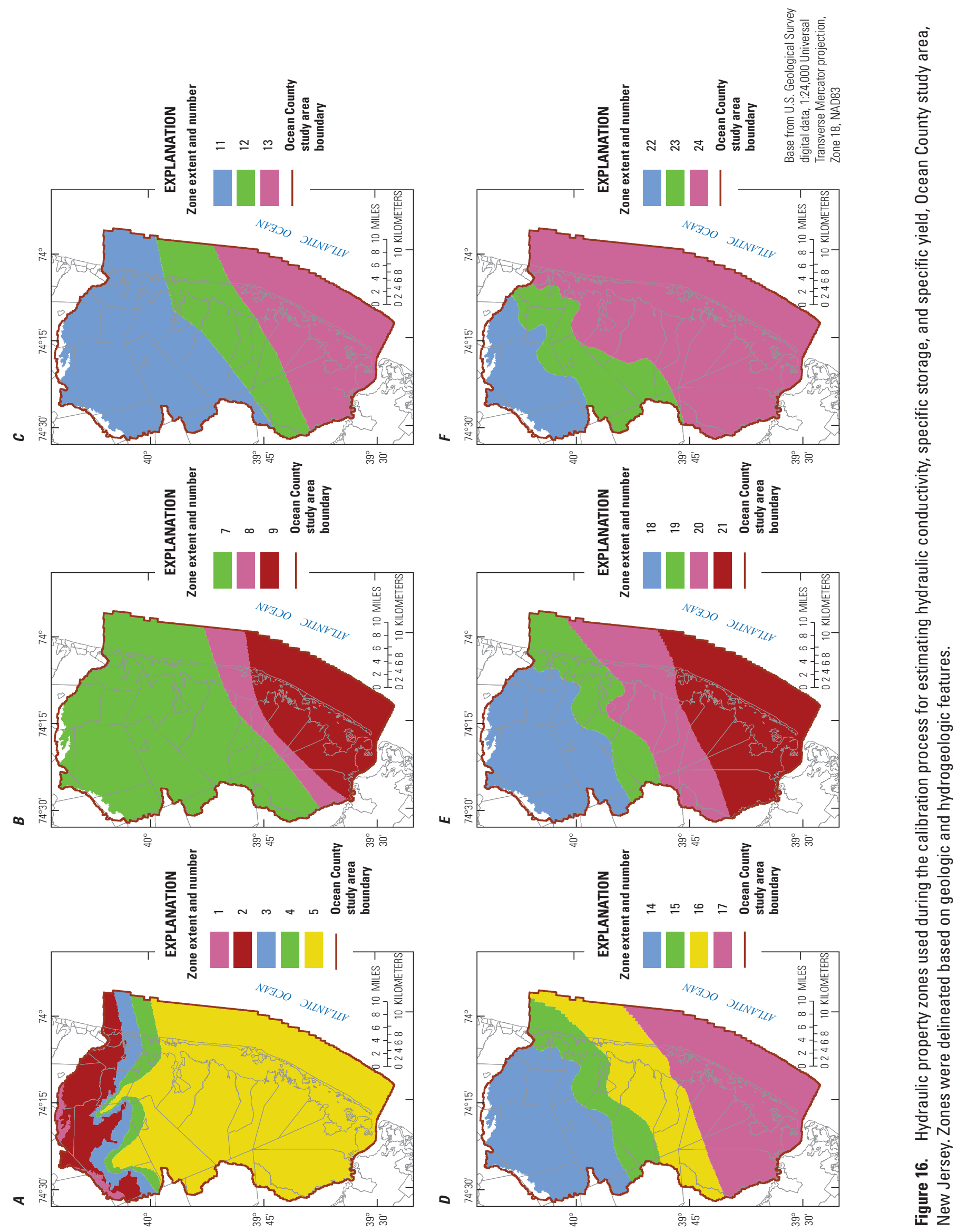
used to calculate weights for water levels are based upon those presented in Chapter C of Belcher (2004) and are shown below.

$\mathrm{SD} 1($ altitude $)=\mathrm{AAC} / 1.96$

$\mathrm{AAC}$ is the GWSI accuracy altitude code, in $\mathrm{ft}$.

$\mathrm{SD} 2($ location $)=(\mathrm{CAC} / 1.96) \times \mathrm{HG}$

CAC is the GWSI coordinate accuracy code, in $\mathrm{ft}$, and $\mathrm{HG}$ is the hydraulic gradient.

$\mathrm{SD} 3($ seasonal fluctuation $)=\mathrm{SF}+(\mathrm{LTC} / 4)$

$\mathrm{SF}$ is the seasonal fluctuation and LTC is the longterm climate trend.

SD4 $($ measurement $)=0.01 / 1.96=0.0051$

(water levels are measured with a steel or electric

tape, and .01 is the assumed accuracy)

$\mathrm{SD}$ is the standard deviation.

The SD due to all errors is calculated as

$\left(\mathrm{SD} 1 \text { (altitude }^{2}+\mathrm{SD} 2 \text { (location) }^{2}+\mathrm{SD} 3 \text { (seasonal) }\right)^{2}+$

SD4(measurement) $\left.)^{2}\right)^{1 / 2}$.

Measurement errors associated with the potential inaccuracy in well altitude and location are computed from the accuracy codes in the USGS GWSI database. Errors associated with the hydraulic gradient are estimated from the 2003 potentiometric surfaces for aquifers in the study area (dePaul and others, 2009) and range from 0.0006 to $0.001 \mathrm{ft} / \mathrm{d}$. Fluctuations in transient water levels that typically result from seasonal and long-term climate change are estimated and range from 0.05 to $15 \mathrm{ft}$ (seasonal) and $1 \mathrm{ft}$ (long term). Variances due to all errors are summed, and the standard deviation for each water level measurement ranges from 0.5 to 3.79 . In order to account for the difference in units between water levels and streamflow and measurement error in streamflow, a weight of 100 is used for streamflow observations.

The most sensitive parameters (CSS greater than 10.0, shown in fig. 17) are rech_north (recharge in the northern part of the study area) rech_south (recharge in the southern part of the study area) riverbedk (streambed hydraulic conductivity); draink (drain hydraulic conductivity) hk15 (horizontal hydraulic conductivity, layer 1, Kirkwood-Cohansey aquifer system) hk48 (horizontal hydraulic conductivity, layer 4, KirkwoodCohansey aquifer system); hk23 (horizontal hydraulic conductivity, layer 2, Kirkwood-Cohansey aquifer system); and hk716 (horizontal hydraulic conductivity, layer 7, Atlantic City 800-foot sand, lower sand).

\section{Model Limitations}

The groundwater-flow model developed for this study is an approximation of a dynamic, real-world groundwater-flow system that covers $1,185 \mathrm{mi}^{2}$ of land and water, extends at the deepest point to nearly 1,000 feet below land surface, and represents five different aquifers. The area of study is divided into discrete model cells that are primarily 800 feet by 800 feet in

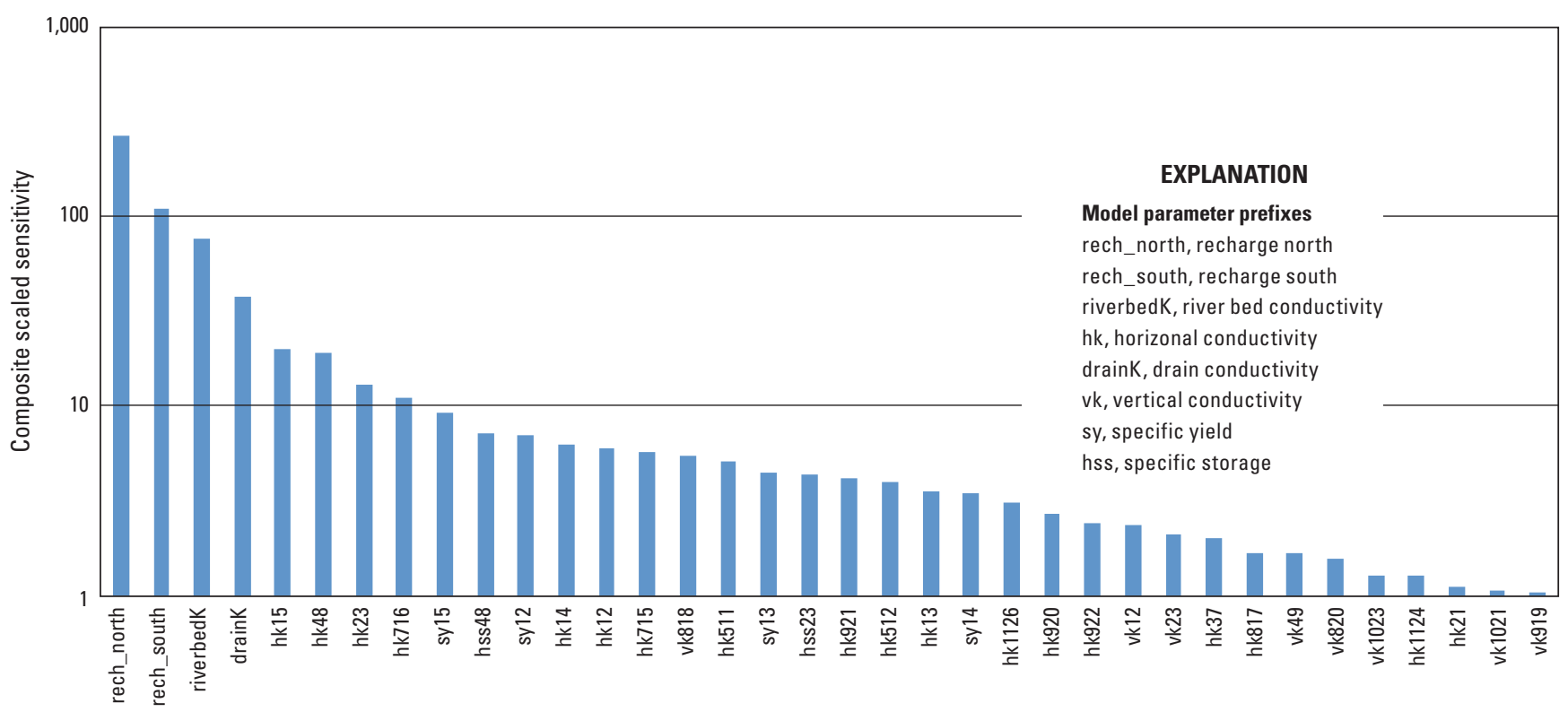

Parameter name

Figure 17. Composite scaled sensitivity values, 0 cean County study area, New Jersey. (Parameters are defined in table 10. Parameters with values great than 1 are shown) 
plan view and of variable thickness. Because of the number of model cells in each model layer $(67,424)$, the number of model layers (11), and the limited data available that describe the hydrologic properties of each layer, the hydrologic parameters in the flow model are generalized and, therefore, do not reflect the total variability that exists in the actual flow system. The groundwater-flow model is calibrated to available data, yet simulated parameter values may not comprise a unique representation of the groundwater-flow system. Parameter estimation techniques were not used in the calibration of this model, and use of these techniques may provide a smaller difference between simulated and measured water levels and base flows, as well as, different simulated parameter values.

The vertical discretization of the hydrogeologic framework into model layers is based on available interpretations of the stratigraphy in the Ocean County study area. The delineation of the contact between the Vincentown aquifer and the Kirkwood-Cohansey aquifer system in the northwestern part of the study area is not well known. In particular, for the area where the Vincentown aquifer becomes confined, the extent and the character of the confining bed have not been mapped in detail because of the limited number of available well logs in this area. The Vincentown aquifer in this area is not very extensive, and its use for public-supply is small. As a result of these constraints, detailed analysis of the Vincentown aquifer is not a goal of this study. The lower sand of the Piney Point aquifer (L.G. Mullikin, New Jersey Geological and Water Survey, written commun., 2001) contains very few water supply wells and detailed analysis of its hydrologic properties is lacking. Model simulation results focus on the upper sand of the Piney Point aquifer.

The study area partially or entirely encompasses more than 36 surface-water basins with extensive surface-water features (fig. 4). The model cell size ( $800 \mathrm{ft}$ by $800 \mathrm{ft}$ ) provides an accurate representation of surface-water features without generating more than 1 million model cells in the 11 layer model, which provides for reasonable model development and run times. A finer discretization of the study area would enhance the resolution of surface-water features by isolating individual stream reaches in more model cells. Improved resolution of surface-water features in the groundwater-flow model could provide more detail in simulated base flows.

The specified flow boundaries of the Ocean County study area model are derived from the revised New Jersey RASA model and are affected by limitations of that model. The RASA model has a larger grid discretization than the Ocean County study area model. Model cells over land surface in the RASA model range in area from 6.25 to $9.375 \mathrm{mi}^{2}$, whereas the area of corresponding cells in the Ocean County study area model is $0.0229 \mathrm{mi}^{2}$. The RASA model has a coarser time discretization than the Ocean County study area model and uses annual time steps; therefore, boundary flows into the Ocean County study area may not represent seasonal changes in these flows. The simulation of no-withdrawal conditions uses boundary heads for several confined aquifers. The boundary heads are derived from published contour maps of pre-pumping heads. The accuracy of pre-pumping groundwater levels are influenced by spatial (lack of numerous, evenly spaced wells at which water levels were recorded) and time-scale (some measurements made after 1900) issues and are considered estimates of the pre-pumping potentiometric surfaces (Zapecza and others, 1987).

\section{Simulated Effects of Groundwater Withdrawals}

The effect of groundwater withdrawals on the groundwater-flow system in the Ocean County study area is evaluated based on three distinct groundwater-model simulations that incorporate different withdrawal schemes or conditions: no-withdrawal conditions, 2000-03 withdrawal conditions, and maximum-allocation withdrawal conditions. No-withdrawal conditions are simulated with monthly recharge values estimated by model calibration, but groundwater withdrawals are excluded from the simulation. This simulation uses prevailing hydrologic conditions without withdrawals to provide a basis for comparison of conditions that may have existed prior to extensive development and use of the groundwater resource. Year 2000-03 conditions are simulated with reported monthly groundwater withdrawals at production wells from January 2000 through December 2003 and monthly recharge rates estimated by model calibration. Maximum-allocation withdrawals are used to simulate a drought scenario in which all the wells in the study area extract the maximum-allocation withdrawal per monitoring period allowed by NJDEP Bureau of Water Allocation permits. To simulate these conditions, input to the flow model is designed so that all groundwater withdrawals occur at existing wells, and monthly recharge rates used in the 2000-03 simulation are incorporated. These simulations allow direct comparison of the response of the groundwater-flow system to different withdrawal conditions.

Monthly allocations for individual wells in the Ocean County study area are estimated on the basis of 2006 permit allocations provided by the NJDEP Bureau of Water Supply and historical withdrawal data. Monthly well allocations are derived from the monthly percentage of a permit allocation attributed to the well on the basis of recorded withdrawals for all wells listed in a permit. Withdrawals from 1987 through 2006 are used to define the monthly percentage of the permit allocations apportioned to each well. Estimated allocations for wells listed under multiple permit allocations are based on the smallest permit allocation that pertains to that well. The sum of the estimated monthly well allocations for each month for all wells governed by the same permit is the highest combination of individual well withdrawals that do not exceed the monthly maximum allocation. The monthly sum of the estimated monthly well allocations for all wells in a permit is the highest combination of individual withdrawals that do not exceed the yearly allocation. 
In general, permit allocations with high monthly maximum allocations and no yearly allocations result in excessively high estimated monthly well allocations. For publicsupply (5000) and industrial (2000P) permit series, wells with no yearly or no monthly maximum allocation are assigned an allocation on the basis of the average ratio of defined yearly allocation limits to defined monthly maximum-allocation limits for all permits within the respective series. For example, the ratio of yearly maximum to monthly maximum-allocation limits for wells used in this study is 7.4 for public-supply withdrawal permits and 6.0 for industrial withdrawal permits. For small volume withdrawal permits $(10,000 \mathrm{~W}$ series), estimated monthly maximum allocations are assumed to be 1.033 million gallons times the number of withdrawal wells in the permit, and the yearly maximum permit allocations are assumed to be 12.4 million gallons times the number of withdrawal wells on the permit. For agricultural permits pertaining to row crops, estimated monthly maximum allocations for June, July, and August are set to the monthly maximum permit allocation; for May, to one-half the monthly maximum allocation; and for the remaining months, to zero. For agricultural permits pertaining to withdrawals for containerized plants and blueberries, yearly allocations are estimated to be 8 times the maximum monthly allocation assigned by the NJDEP.

Groundwater withdrawals from the shallow KirkwoodCohansey aquifer system causes a reduction in base flow in the streams in the study area. Groundwater flow that normally discharges to surface-water features under non-withdrawal conditions is diverted to supply wells. Results from stress periods $64,73,77,80$, and 87 , which simulate monthly recharge conditions similar to November 2001, August 2002, December 2002, March 2003, and October 2003, respectively, are examined in detail to illustrate how the flow system responds to these conditions. Stress period 64 (November 2001 recharge) is a time of zero recharge following 2 months of low recharge. Stress period 73 (August 2002 recharge) is a month of slightly low recharge following 4 months of low recharge, and stress period 77 (December 2002 recharge) is a month of high recharge preceded by 2 months of high recharge. Stress period 80 (March 2003 recharge) is a month of slightly high recharge following 5 months of high recharge, and stress period 87 (October 2003 recharge) has average recharge proceeded by 3 months of low to average recharge in the study area. The following discussion examines simulations of three different withdrawal conditions and their effect on base-flow values at streamflow-gaging stations on streams that drain into the Barnegat Bay-Little Egg Harbor estuary or Great Bay.

The effects of seasonal changes in recharge to, and groundwater withdrawals from, the groundwater-flow system is evaluated by examining water levels in the major confined aquifers in the Ocean County study area for August 2002 and March 2003 recharge conditions. May 2002 to August 2002 is a period with low simulated water levels and base flow, in part due to average estimated monthly groundwater recharge of 0.9 inch. Evapotranspiration is high and groundwater withdrawals typically increase during the summer; groundwater levels usually reach the lowest point of the year in late summer or early fall. Evapotranspiration decreases from October through March due to cooler temperatures and diminished plant growth and respiration. As a result, March 2003 is a period with relatively high water levels and base flow. The average estimated monthly groundwater recharge for October 2002 through March 2003 is 2.7 inches (table 9), nearly double the average estimated monthly recharge of 1.4 inches for 2000 through 2003 in the Ocean County study area. Stress period 73 (August 2002 recharge) and stress period 80 (March 2003 recharge) represent contrasts in recharge and withdrawals during the simulation period (table 9) and are used in the following discussion to illustrate the response of water levels to these conditions.

\section{No-Withdrawal Conditions}

A groundwater budget of flow into, and out of, the Kirkwood-Cohansey aquifer system during five stress periods can be used to illustrate how the groundwater-flow system responds to conditions without groundwater withdrawals (fig. 18A). Analysis of stress period 64 (November 2001 recharge), stress period 73 (August 2002 recharge), stress period 77 (December 2002 recharge), stress period 80 (March 2003 recharge), and stress period 87 (October 2003 recharge) indicates that the largest and most variable component of water entering the groundwater-flow system is recharge ( 0 to 2,290 cubic feet per second $\left[\mathrm{ft}^{3} / \mathrm{s}\right]$ ), followed by net flow into storage ( 27 to $602 \mathrm{ft}^{3} / \mathrm{s}$ ). The largest component of groundwater flow out of the Kirkwood-Cohansey aquifer system, 484 to $1,086 \mathrm{ft}^{3} / \mathrm{s}$, flows to all streams (fig. 18A). Water in the Kirkwood-Cohansey aquifer system enters storage during high recharge conditions (net flow of 1,043 ft $\mathrm{ft}^{3} / \mathrm{s}$ in stress period 77), flows out to wetlands and the ocean that are represented as constant head cells in the model (107 to $136 \mathrm{ft}^{3} / \mathrm{s}$ ) and out to adjacent aquifers ( 9 to $27 \mathrm{ft}^{3} / \mathrm{s}$ ) during the examined stress periods. Simulation of no-withdrawal conditions indicates that flow is less than $1 \mathrm{ft}^{3} / \mathrm{s}$ into and out of the Rio Grande waterbearing zone and the Atlantic City 800-foot sand for selected stress periods and less than $2.5 \mathrm{ft}^{3} / \mathrm{s}$ into and out of the Piney Point aquifer, in the Ocean County study area (figs. 18B, C, and $D$ ). Groundwater flow to streams, which subsequently discharges into the Barnegat Bay-Little Egg Harbor estuary, ranges from 326 to $759 \mathrm{ft}^{3} / \mathrm{s}$ per stress period due to the simulated conditions.

Wells 29-141, 29-1060, and 29-513 (figs. 19A, B, and $C$, respectively) are screened in the unconfined KirkwoodCohansey aquifer system; simulated water levels in these wells respond to variable recharge under the conditions of nowithdrawal that are depicted. Simulated water levels in wells screened in confined aquifers show little response to variations in recharge (figs. $19 E-L, 19 N$, and $O$ ), except at observation well 29-425, screened in the Piney Point aquifer (fig. 19M). This well is in the west-central part of the study area close to the updip boundary of the aquifer. Water levels from 

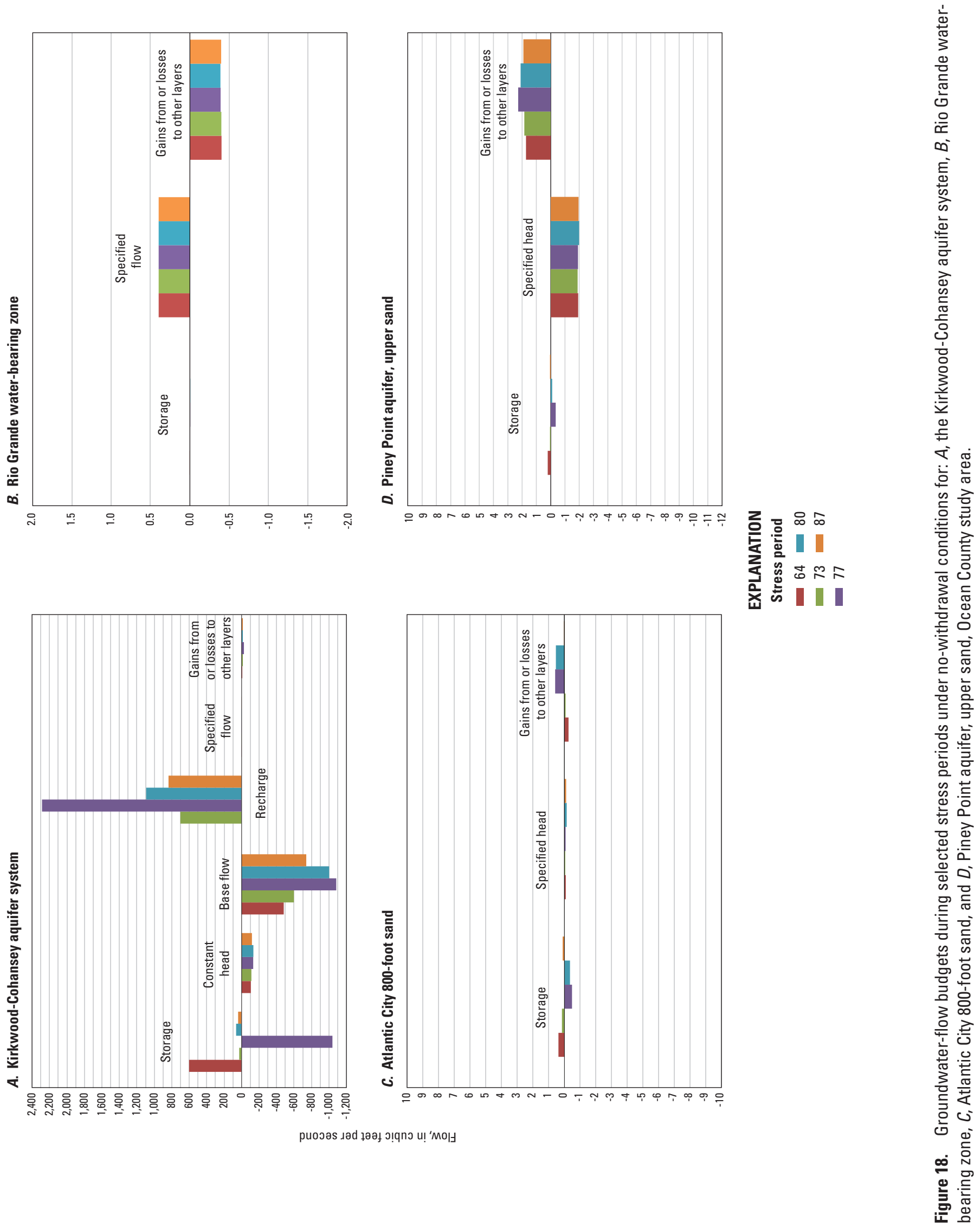

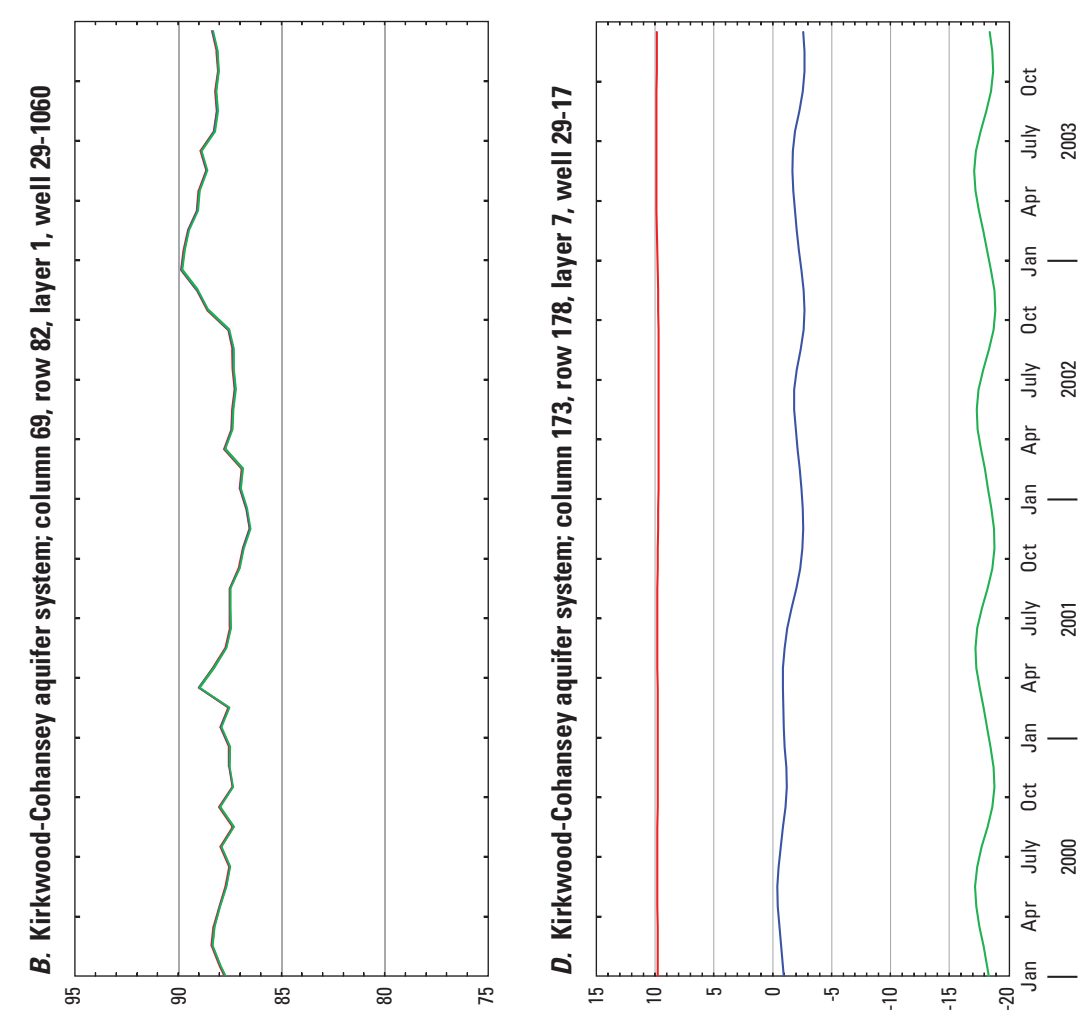

完.

穴产

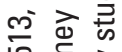

定高

心㝘完

它桴

完定 。

o'

守空害

定 \&

仿

옹

3 它

헝

농

क⿺辶一兀

言灾 응

王

बे

뜽 증

心

놓을 흥

3

高要

항

访
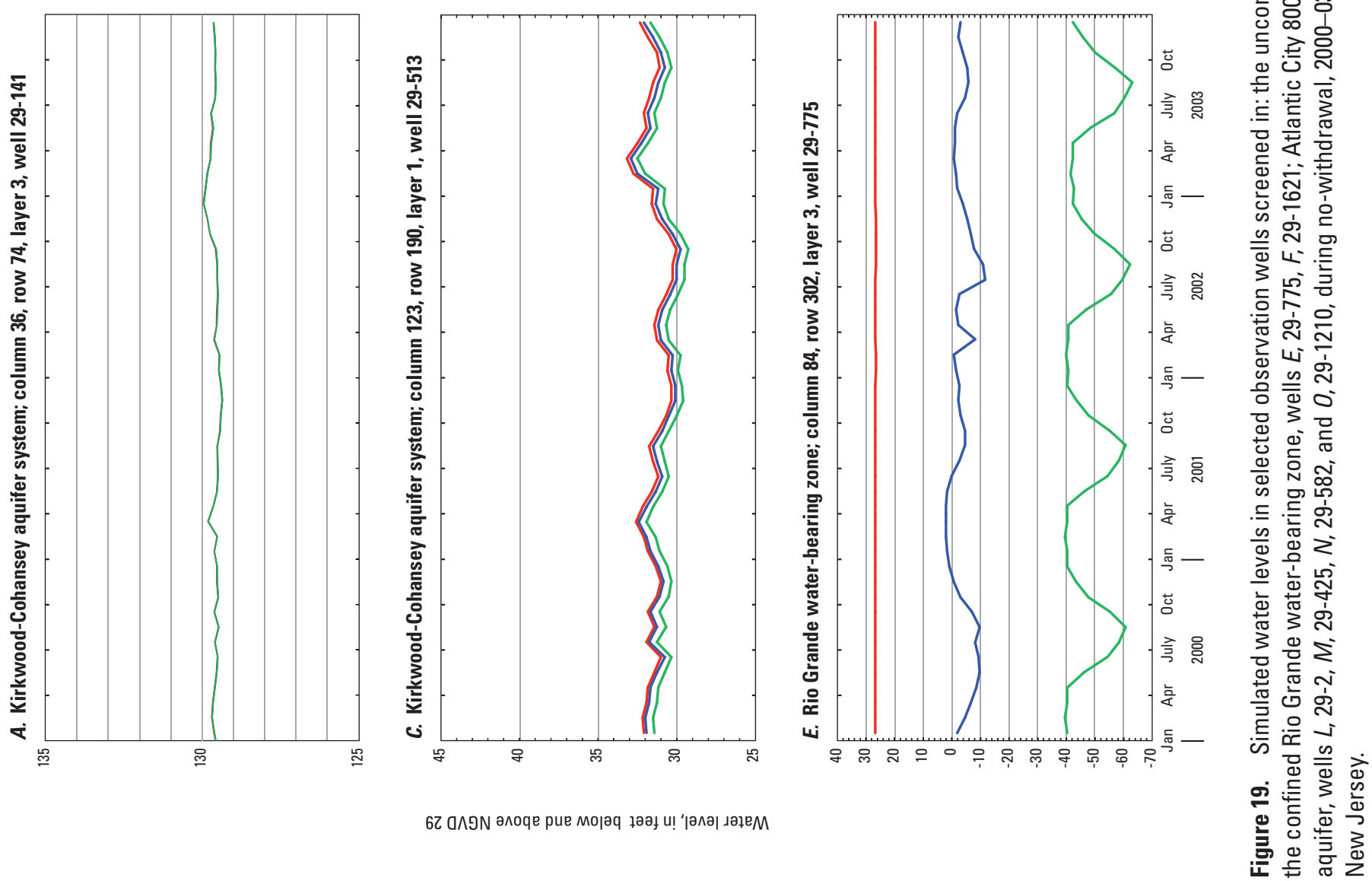

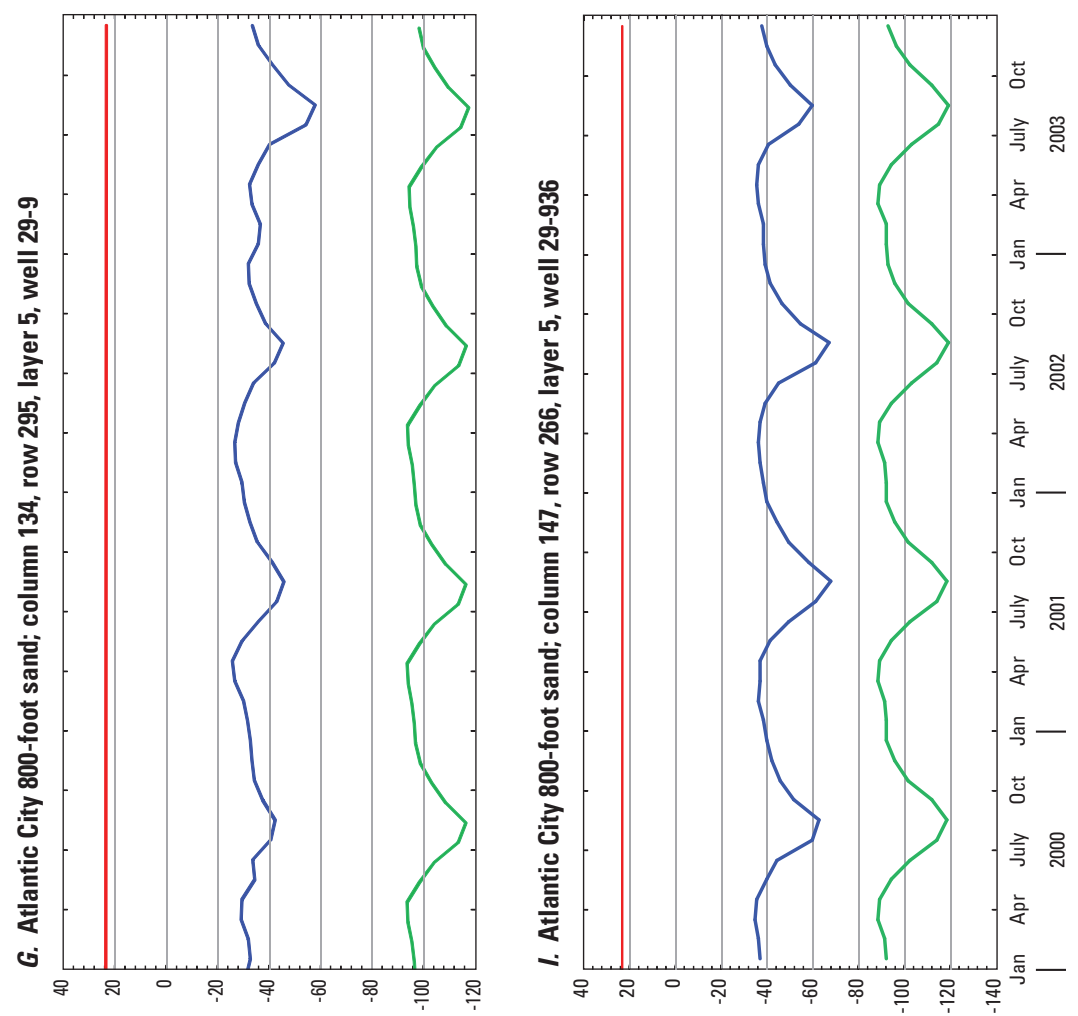

సั่

ऽ 흥

ल खे

守

心㝘

ठ্ঠি

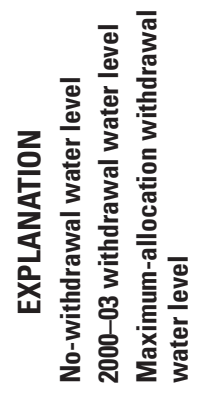

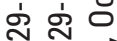

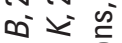

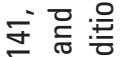

定 过

एं

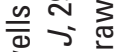

उ

ब依

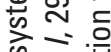

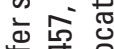

言 完

王

बे के

范

o

紊 $\frac{\infty}{\overline{0}}$ 亭

उ $\bar{\pi}$

妾运

需

要

的
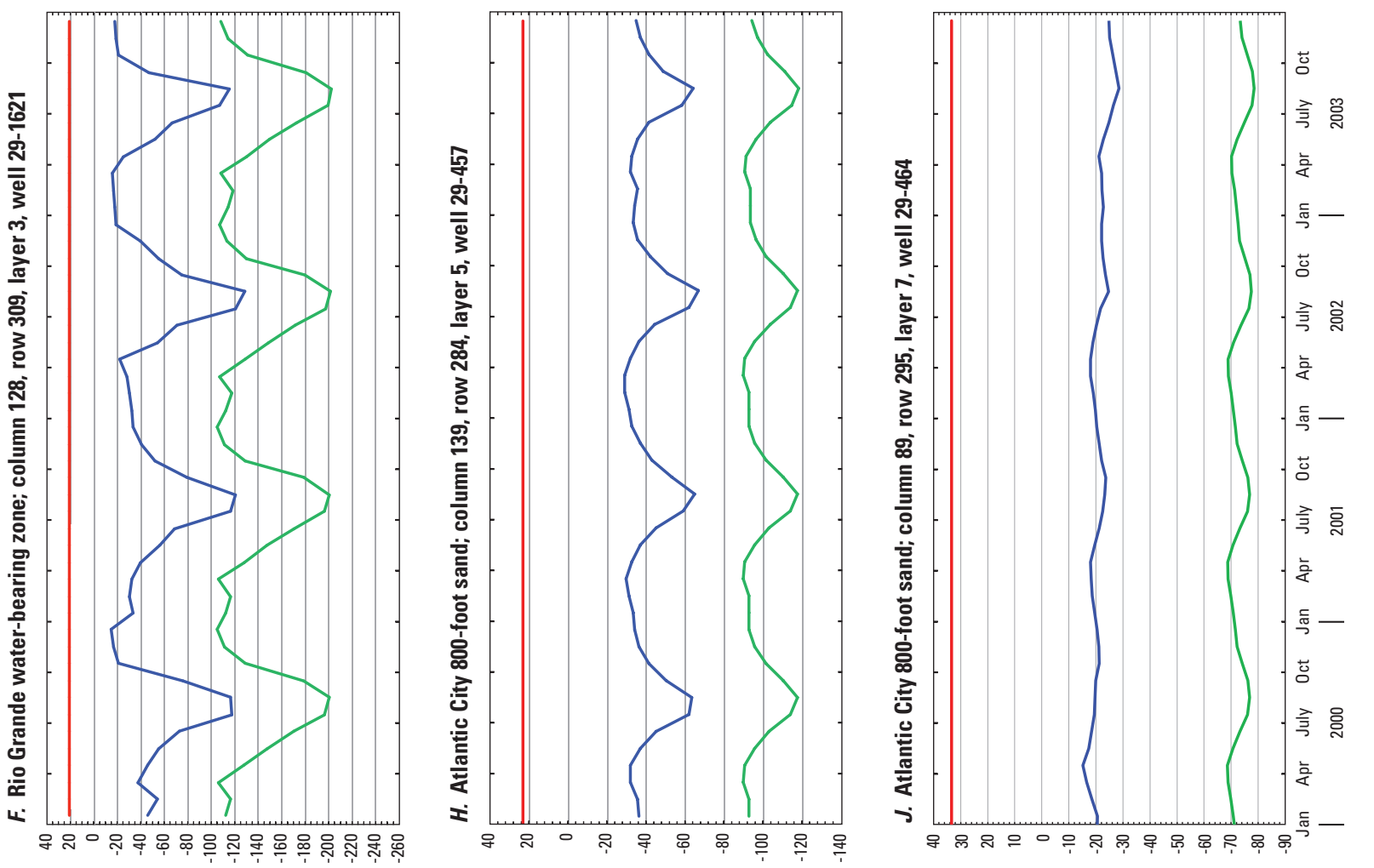

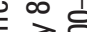

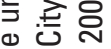

․ㅡㄹ

证䨟

당

ब त

is

인

了战

등

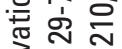

넝

号贸

잉

Uू

잉

.

禹

ฮ 는

雪

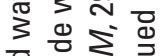

旅

宁完

트 은 닌

垴

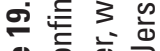

인 인

言过壳总 

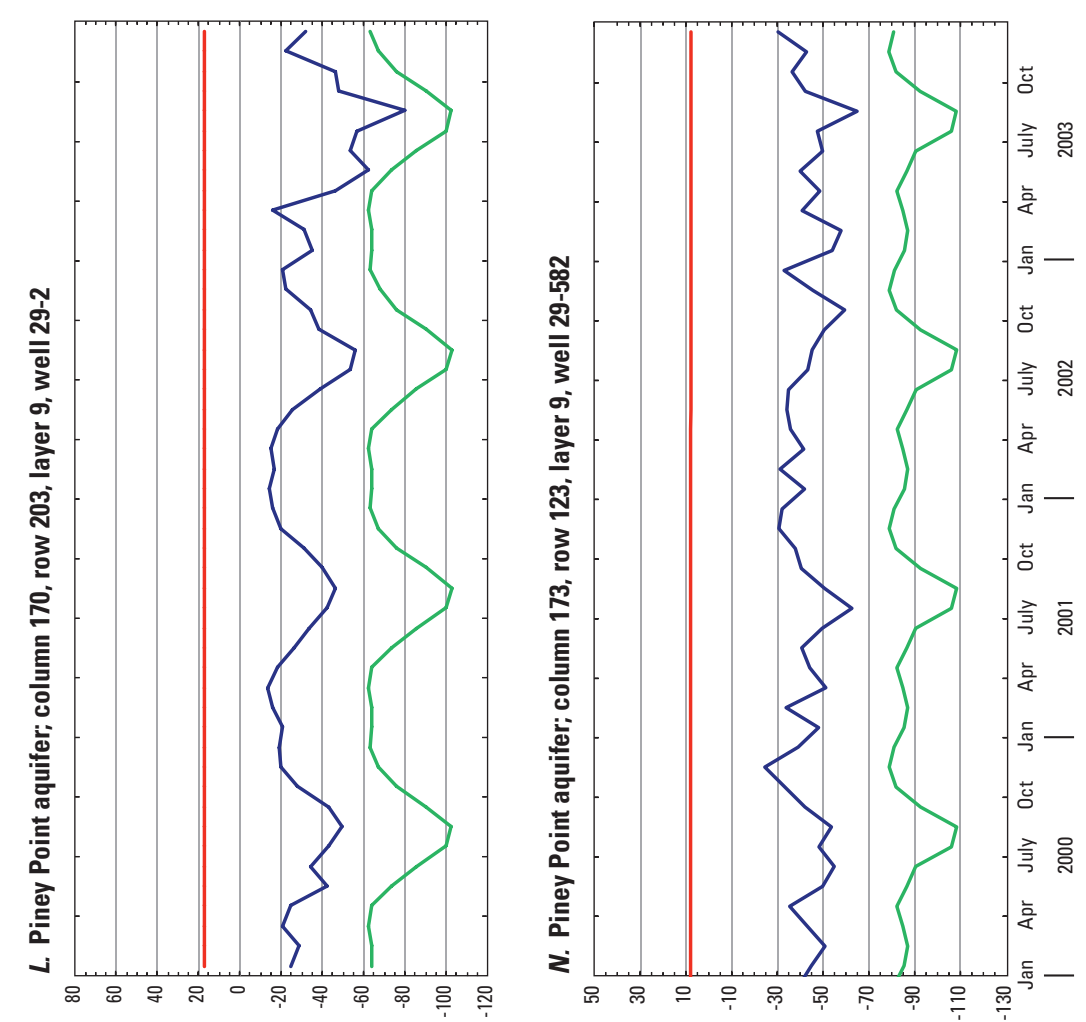

穴

ㄷำ

m

ช่

ن흥

ठீㅇㅇ

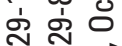

D

허음

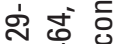

ष' ত্ণ

业 元

ज़ ले

텅 क्

点 든.

๘

흠 임

वे

बें के

官 어ํ

ᄃิ

立 응

3 त

흔 진

응

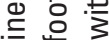

등용
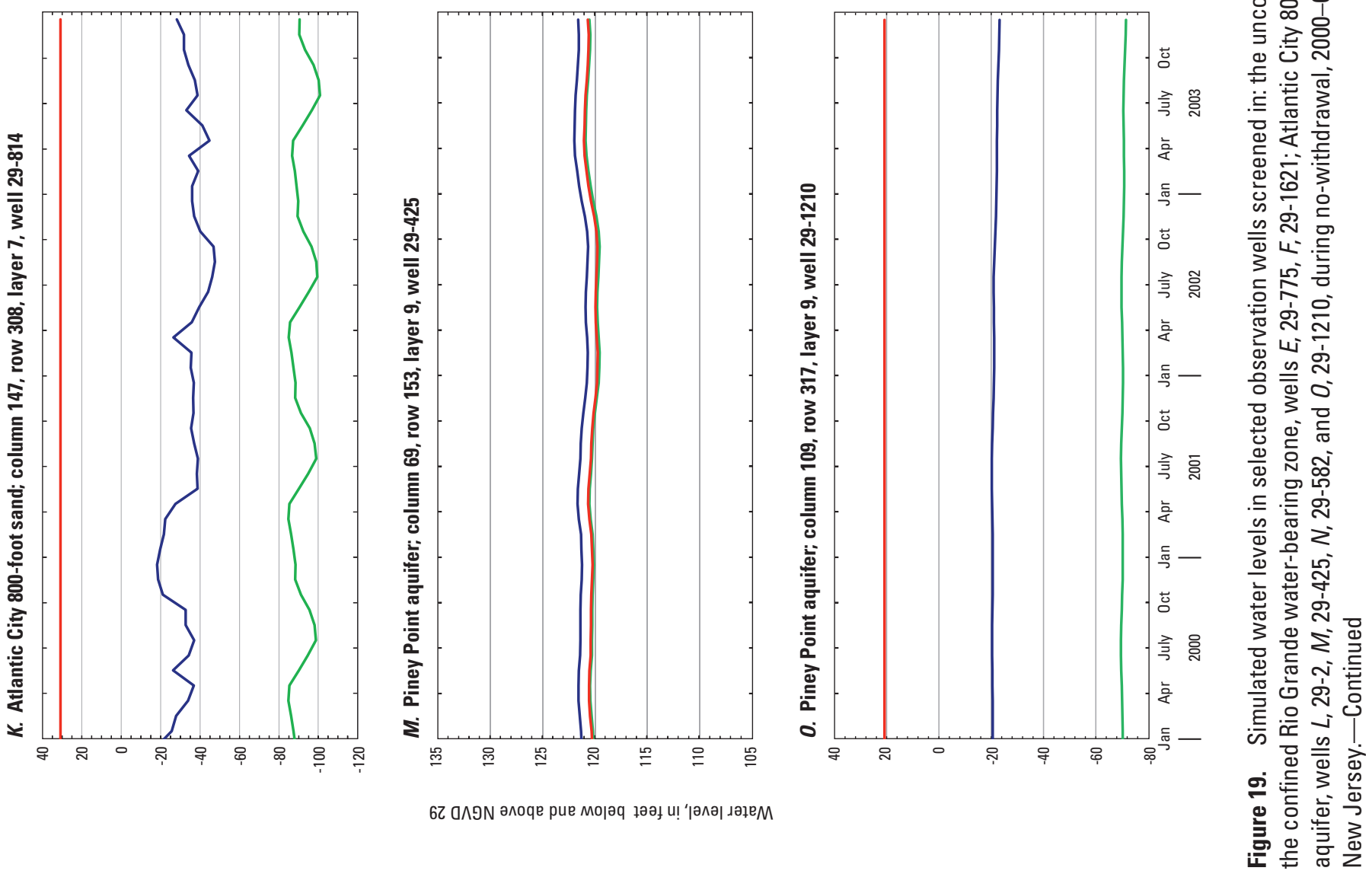
no-withdrawal conditions range from 119 to 121 feet in this well. The updip area of the Piney Point aquifer appears to be more affected by fluctuations in the water table than downdip areas. The confining unit overlying the Piney Point aquifer in the updip area may contain sediments that are more transmissive than sediments that comprise the confining unit in the downdip area, and as a result, the Piney Point aquifer might have a hydraulic connection with the overlying water table.

\section{0-03 Withdrawal Conditions}

Withdrawal conditions during the years 2000 to 2003, are simulated using monthly groundwater withdrawals from wells in the Ocean County study area. Water budgets for each aquifer during stress periods 64, 73, 77, 80 and 87 (with November 2001, August 2002, December 2002, March 2003, and October 2003 recharge, respectively; fig. 20) illustrate the impact of the simulated conditions on the groundwater-flow system. Because of the withdrawals ( 24 to $42 \mathrm{ft}^{3} / \mathrm{s}$ ), 6 to 10 percent less groundwater flows out of the Kirkwood-Cohansey aquifer system into streams (437 to $1,025 \mathrm{ft}^{3} / \mathrm{s}$ combined net flux) than for the no-withdrawal simulation. Simulated flow out of the Kirkwood-Cohansey aquifer system to constant head cells ranges from 99 to $129 \mathrm{ft}^{3} / \mathrm{s}$ (fig. 20A), a reduction of 5 to 8 percent. Net flow out of the Kirkwood-Cohansey aquifer system to adjacent layers ranges from 33 to $49 \mathrm{ft}^{3} / \mathrm{s}$, an increase of 27 to 55 percent from no-withdrawal conditions.

Groundwater withdrawals from the Kirkwood-Cohansey aquifer system (24 to $42 \mathrm{ft}^{3} / \mathrm{s}$ ) and the Rio Grande waterbearing zone ( 0 to $0.7 \mathrm{ft}^{3} / \mathrm{s}$ ) cause net flow into the Rio Grande water-bearing zone from adjacent layers $\left(0.3\right.$ to $\left.0.7 \mathrm{ft}^{3} / \mathrm{s}\right)$ (fig. 20B). Groundwater withdrawals from the Atlantic City 800 -foot sand (12 to $30 \mathrm{ft}^{3} / \mathrm{s}$ ) cause flow into this aquifer from other layers (15 to $21 \mathrm{ft}^{3} / \mathrm{s}$ ) (fig. 20C). The net inflow to the Rio Grande water-bearing zone and Atlantic City 800-foot sand in this simulation reflects a change in flow direction from no-withdrawal conditions, where flow is generally out to other layers. Withdrawals from the Piney Point aquifer during 2000-03 withdrawal conditions ( 3.7 to $7.5 \mathrm{ft}^{3} / \mathrm{s}$ ) result in higher net groundwater flow into the aquifer from other layers (3.8 to $4.7 \mathrm{ft}^{3} / \mathrm{s}$ ) (fig. 20D). Groundwater withdrawals from all confined aquifers are largest during stress period 73 (August 2002 recharge), of the five stress periods examined, which causes the largest in flow from storage and other layers in the confined aquifers.

Simulated groundwater withdrawals from the KirkwoodCohansey aquifer system cause a reduction in base flow that is evaluated by comparing base flow at streamflow-gaging stations from the no-withdrawal simulation to base flow at the same stations during a simulation of 2000-03 withdrawal conditions. Simulated 2000-03 withdrawals cause base-flow reductions at all simulated streamflow-gaging stations locations in the Ocean County study area with 6 of the 12 stations having average simulated reductions of less than $1 \mathrm{ft}^{3} / \mathrm{s}$ (table 11). The smallest reduction in simulated base flow from no-withdrawal to 2000-03 withdrawal conditions occurs at streamflow-gaging station Cedar Run near Manahawkin, N.J. (01409250), which decreases by a minimum of $0.03 \mathrm{ft}^{3} / \mathrm{s}$ and a maximum of $0.11 \mathrm{ft}^{3} / \mathrm{s}$. Larger base-flow reductions than those simulated for Cedar Run occurred at streamflow-gaging stations Wrangel Brook at Mule Road near Toms River, N.J. (01408592); South Branch Metedeconk River near Lakewood, N.J. (01408150); Toms River near Toms River, N.J. (01408500); Cedar Creek at Lanoka Harbor, N.J. (01409000); and Oswego River at Harrisville, N.J. (01410000). The largest reduction in base flow between the two simulations occurs at the location of Toms River near Toms River, N.J. (01408500) streamflow-gaging station, which has a minimum decrease of 6.8 and a maximum of $9.5 \mathrm{ft}^{3} / \mathrm{s}$.

The percent reduction in base flow from no-withdrawal to 2000-03 withdrawal conditions indicates that all streamflowgaging stations had less than a 9-percent reduction. Streamflow-gaging stations Wrangel Brook at Mule Road near Toms River, N.J. (01408592), and North Branch Metedeconk River near Lakewood, N.J. (01408120), in the northern part of the study area had the highest percent and highest average percent reductions in base flows, whereas Cedar Creek at Lanoka Harbor, N.J. (01409000), and Oswego River at Harrisville, N.J. (01410000), in the central and southern part of the study area, respectively, had the lowest percent reductions.

During extended periods of little or no precipitation, streamflow in the Coastal Plain of New Jersey can be entirely from base flow. During periods of normal precipitation, the total amount of streamflow at any point in a stream includes both base flow and overland flow from storms. The total baseflow rate in streams that drain into the Barnegat Bay-Little Egg Harbor estuary is calculated for selected stress periods of each model simulation (table 12). The amount of base flow that reaches Barnegat Bay-Little Egg Harbor estuary is dependent on the amount of precipitation that falls on the land surface and ultimately recharges the surficial aquifer and the amount of groundwater withdrawn from the shallow aquifer system, as well as the location of streams and drains that influence the directions of flow within the unconfined and confined aquifers. Of the stress periods examined, stress period 77 (December 2002 recharge) had a high rate of simulated recharge to the aquifer and the highest amount of simulated base flow out of the aquifer to streams that flow into the Barnegat Bay-Little Egg Harbor estuary.

Results of 2000-03 withdrawal conditions indicate that for stress period 64 (November 2001 recharge) simulated base flow to streams that flow into the Barnegat Bay-Little Egg Harbor estuary $\left(287 \mathrm{ft}^{3} / \mathrm{s}\right)$ is less than half of base flow $\left(710 \mathrm{ft}^{3} / \mathrm{s}\right)$ for stress period 77 (December 2002 recharge), as a result of much lower seasonal recharge rates (table 12). Simulation of 2000-03 withdrawal conditions indicate there is $39 \mathrm{ft}^{3} / \mathrm{s}$ (12 percent) less base flow reaching the Barnegat BayLittle Egg Harbor estuary during stress period 64 (November 2001 recharge) and $49 \mathrm{ft}^{3} / \mathrm{s}$ (6.4 percent) less during stress period 77 (December 2002 recharge) due to groundwater withdrawals than during the no-withdrawal simulations. 

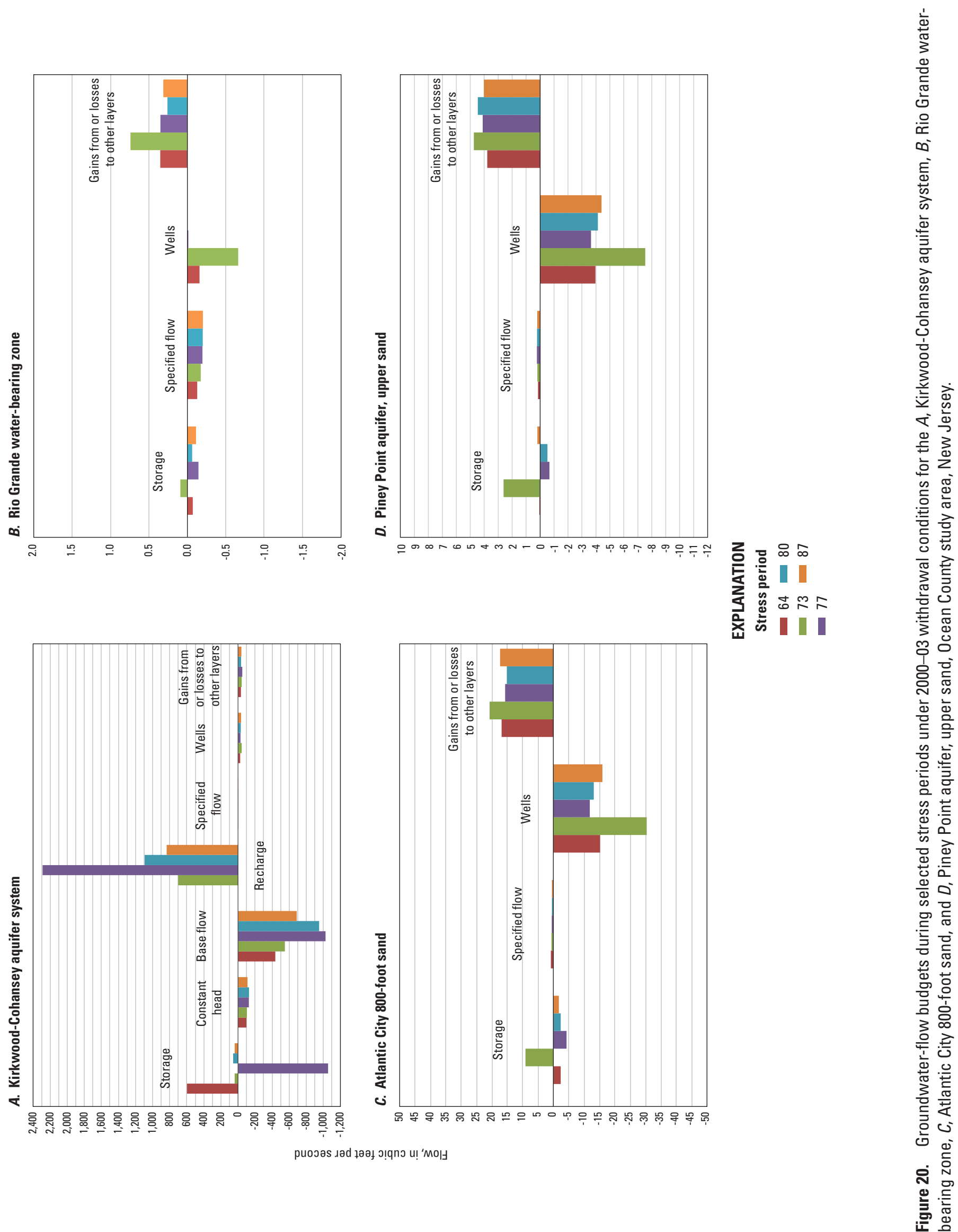
Table 11. Simulated base-flow reductions at selected streamflow-gaging stations from no-withdrawal to 2000-03 withdrawal and maximum-allocation withdrawal conditions, 0cean County study area, New Jersey.

[fts/s, cubic feet per second; \%, percent; Min., minimum; Max., maximum; Avg., average; -, not calculated]

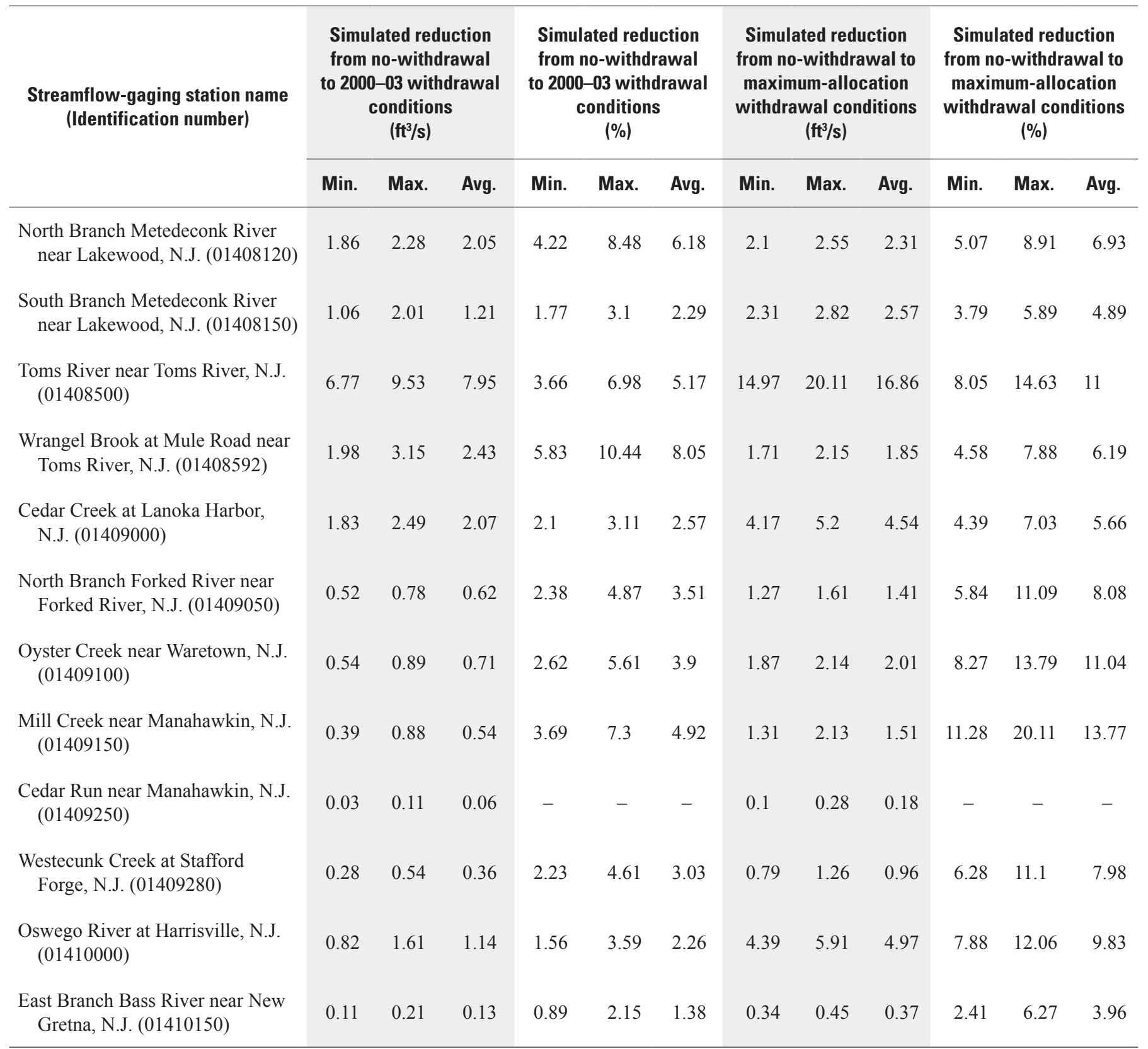

Simulated water levels from 2000-03 withdrawal conditions at wells 29-141, 29-513, and 29-1060 screened in the Kirkwood-Cohansey aquifer system are less than $1 \mathrm{ft}$ lower than they would be based on no-withdrawal conditions alone (fig. 19A-C). Simulated water levels in well 29-17 are 12.1 and 11.7 feet lower during stress periods 73 and 80 (August 2002 and March 2003 recharge, respectively) than they would be under no-withdrawal conditions (fig. 19D). Wells 29-141, 29-513, and 29-1060 are screened 50 feet or less below the land surface. The small response in groundwater levels at these wells is typical of wells completed in the shallow, unconfined water-table aquifer. Well 29-17 is screened 377 feet below land surface, and the groundwater-level response in this well is indicative of semiconfined conditions at depth.

The simulated potentiometric surfaces of the Rio Grande water-bearing zone (fig. $19 E$ and $F$ ) during stress periods 73 (August 2002 recharge) and 80 (March 2003 recharge), examined at wells 29-775 and 29-1621, indicate substantial declines from no-withdrawal conditions to 2000-03 conditions as a result of groundwater withdrawals. Simulated groundwater levels in these wells declined approximately 38 to 150 feet in stress period 73 (August 2002 recharge) and 27 to 37 feet in 
Table 12. Simulated base flow to streams that flow into the Barnegat Bay-Little Egg Harbor estuary, stress periods 64 (November 2001), 73 (August 2002), 77 (December 2002), 80 (March 2003), and 87 (October 2003), Ocean County study area, New Jersey.

[Location of Ocean County study area is shown in figure 1 ; $\mathrm{ft}^{3} / \mathrm{s}$, cubic feet per second]

\begin{tabular}{|c|c|c|c|c|}
\hline $\begin{array}{l}\text { Stress } \\
\text { period }\end{array}$ & $\begin{array}{l}\text { Simulation } \\
\text { date }\end{array}$ & $\begin{array}{c}\text { No-withdrawal } \\
\text { conditions, base flow } \\
\left(\mathrm{ft}^{3} / \mathrm{s}\right)\end{array}$ & $\begin{array}{c}2000-03 \\
\text { withdrawal } \\
\text { conditions, base flow } \\
\left(\mathrm{ft}^{3} / \mathrm{s}\right)\end{array}$ & $\begin{array}{c}\text { Maximum allocation } \\
\text { withdrawal } \\
\text { conditions, base flow } \\
\left(\mathrm{ft}^{3} / \mathrm{s}\right)\end{array}$ \\
\hline 64 & November 2001 & 326 & 287 & 262 \\
\hline 77 & December 2002 & 759 & 710 & 681 \\
\hline 80 & March 2003 & 674 & 630 & 602 \\
\hline 87 & October 2003 & 512 & 466 & 441 \\
\hline
\end{tabular}

stress period 80 (March 2003 recharge). Groundwater levels in the Rio Grande water-bearing zone exhibit large seasonal fluctuations in areas close to the center of the cone of depression in the southern part of Long Beach Island (fig. 21) as reflected in the simulated hydrograph for well 29-1621 (fig. 19F). The simulated change in water levels at this well is sometimes as great as 100 feet over the course of a year due to seasonal withdrawals.

Regional water levels in the Rio Grande water-bearing zone simulated for 2000-03 withdrawal conditions range from an altitude of -40 to -60 feet during stress period 73 (August 2002 recharge) to -10 to -20 feet during stress period 80 at the southern end of Long Beach Island (fig. 21). Drawdown of nowithdrawal potentiometric surfaces to $2000-03$ potentiometric surfaces are illustrated for the confined aquifers during stress period 73 (August 2002 recharge) and represent maximum differences due to seasonal lows in water levels (fig. 22A). Regional drawdown of the Rio Grande water-bearing zone potentiometric surface along Long Beach Island ranges from 20 feet near the northern part of the barrier island to 60 to 80 feet near the southern end. Drawdowns at well 29-1621 in Holgate are larger than elsewhere.

During 2000-03 withdrawal conditions, seasonal variations in water levels in the Atlantic City 800-foot sand, upper and lower sands, vary as much as 13 to 38 feet (figs. 19G, $H, I, J$, and $K$ ) and the simulated potentiometric surfaces are very similar in both sands. During no-withdrawal conditions, stress periods 73 and 80 , the potentiometric surface is at an altitude of 20 feet in Barnegat Light Borough. In response to large groundwater withdrawals from this aquifer in Atlantic County (18 to 24 million gallons per day, 1978-2003), a cone of depression developed near Margate City, N.J., (dePaul and others, 2009). Measured water levels in the Atlantic City 800 -foot sand within the center of the cone of depression, just north of Margate City were at an altitude of -90 feet in 2003 (dePaul and others, 2009). The northern edge of this regional cone of depression extends into Ocean County at an altitude of -20 feet just south of Barnegat Light Borough. Simulated 2000-03 water levels during stress period 87 (October 2003 recharge) are very similar to mapped 2003 water levels (dePaul and others, 2009; fig. $11 C$ and $D$ ). Regional water levels in the Atlantic City 800 -foot sand, simulated for 2000-03 withdrawal conditions, range from -20 feet at Surf City Borough to the southern end of Long Beach Island during stress period 80 to -40 feet at Surf City Borough south to Beach Haven Borough during stress period 73 (figs. 23B and $E$ ). Simulation of 2000-03 withdrawals from the Atlantic City 800 -foot sand indicates regional drawdowns ranging from 20 to 80 feet (figs. $22 B$ and $C$ ) from simulated no-withdrawal water levels during stress period 73. Simulated regional drawdown of the Atlantic City 800-foot sand potentiometric surface ranges from 60 to 80 feet centered on the Long Beach Island communities of Surf City, Ship Bottom, and Beach Haven Boroughs and Long Beach Township, with larger drawdowns simulated at withdrawal wells (figs. $22 B$ and $C$ ).

The differences between no-withdrawal and 2000-03 simulated water levels for wells 29-2, 29-425, 29-582, and 29-1210, screened in the Piney Point aquifer (fig. 19L-O), range from less than 1 foot to 73 feet at these wells during stress periods 73 (August 2002 recharge) and 80 (March 2003 recharge). The center of the cone of depression in the potentiometric surface of the Piney Point aquifer simulated for 2000-03 withdrawal conditions is located in Barnegat Light Borough (figs. 2 and 24) near well 29-2 (fig. 19L). Well 29-1210, south of the center of the cone of depression in Barnegat Light Borough (fig. 19O), exhibits a smaller decline of approximately 40 feet in water levels. Simulated water levels in well 29-425, in the northwest part of the study area, far from the cones of depression centered in Barnegat Light and Seaside Park Boroughs (figs. 19M and 24) does not indicate declining water levels.

The simulated potentiometric surface of the Piney Point aquifer, upper sand, during stress periods 73 (August 2002 recharge) and 80 (March 2003 recharge) from no-withdrawal 

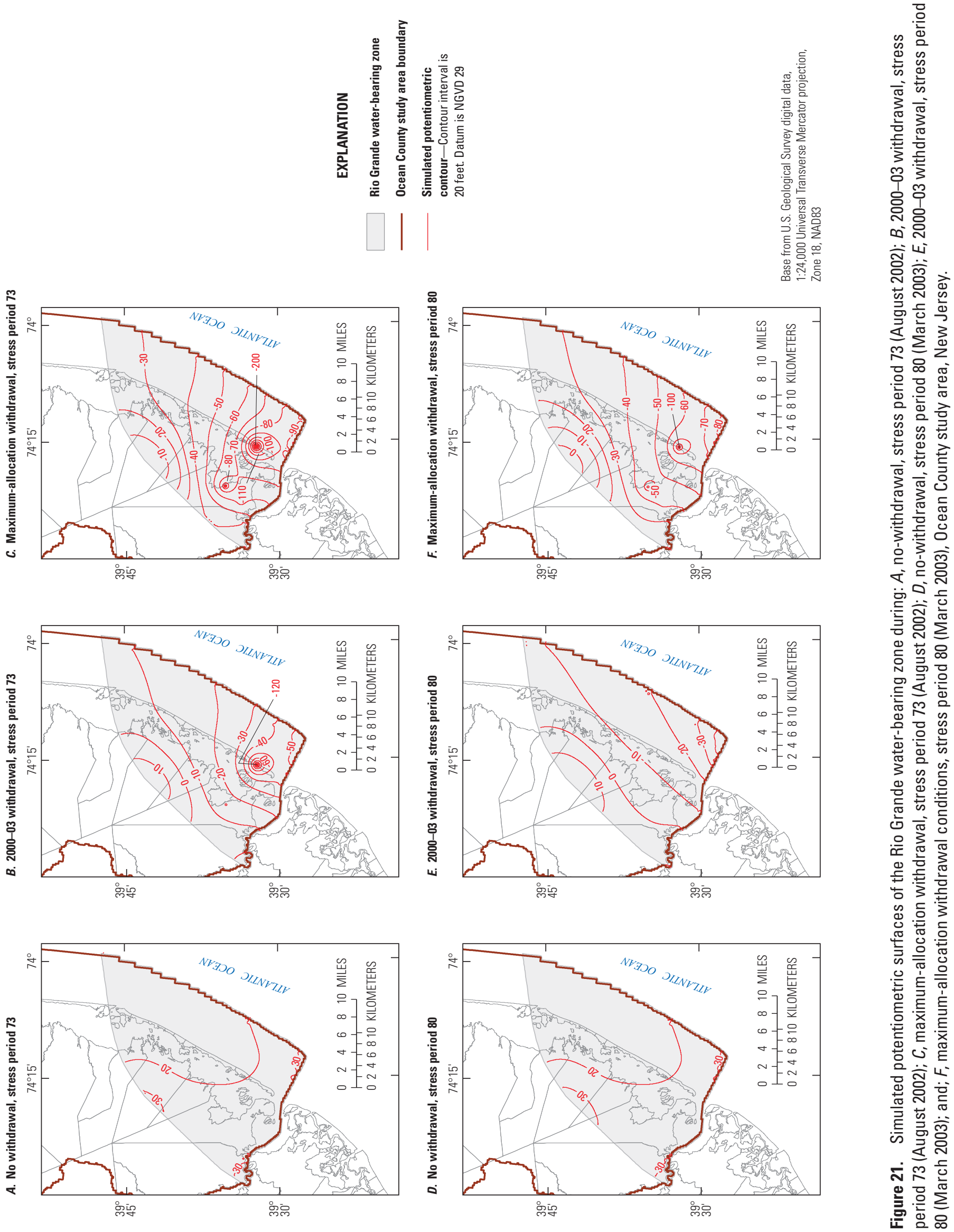

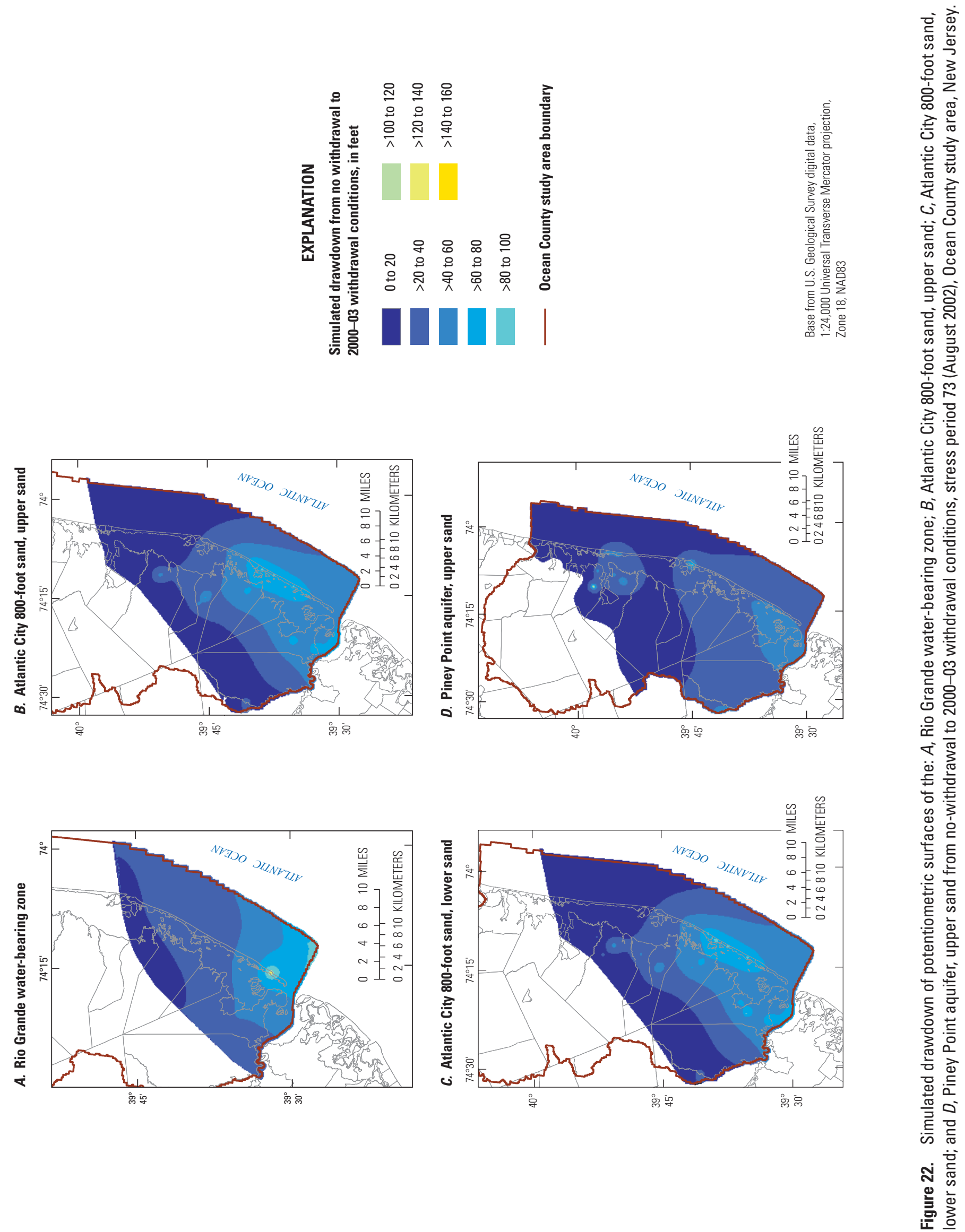

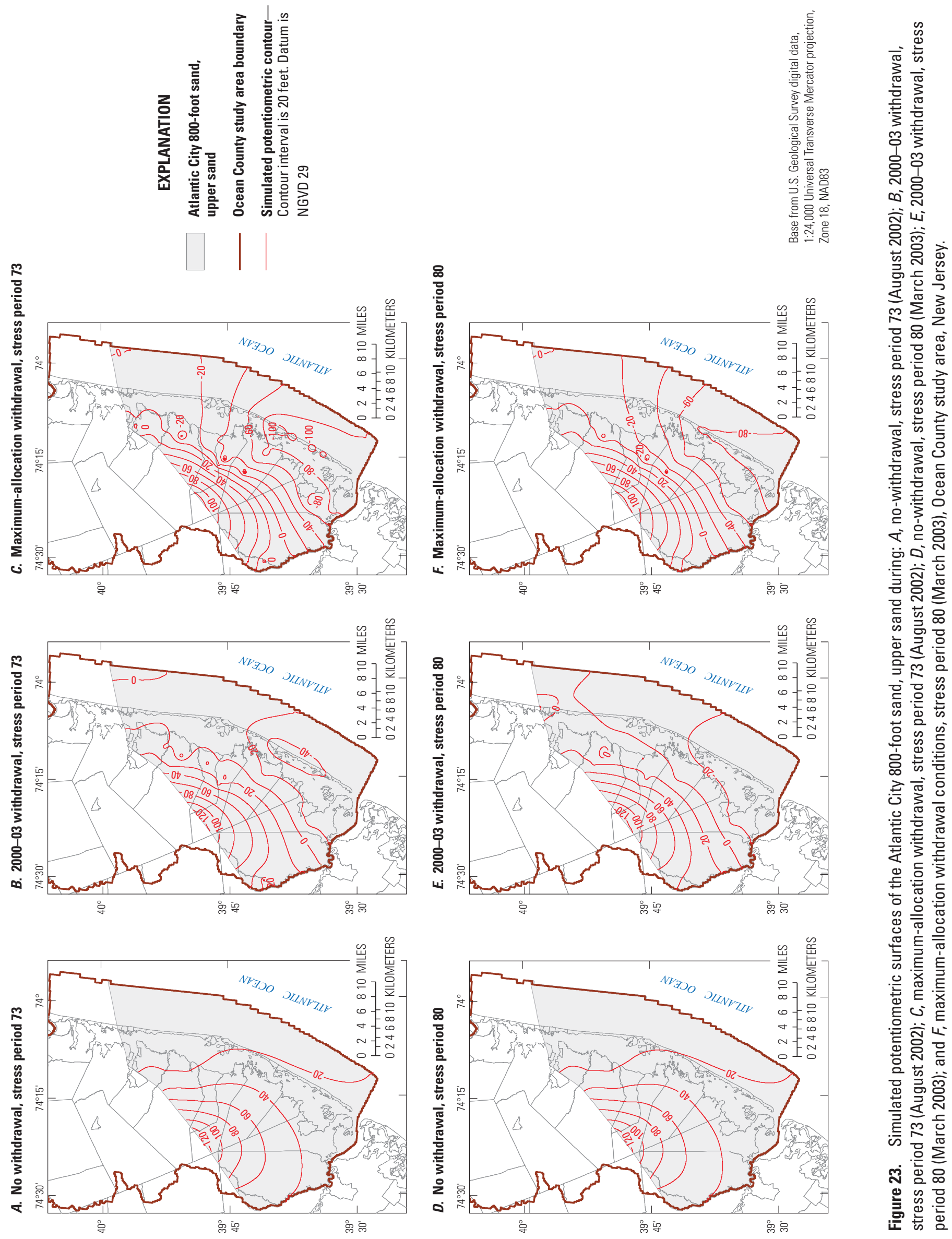

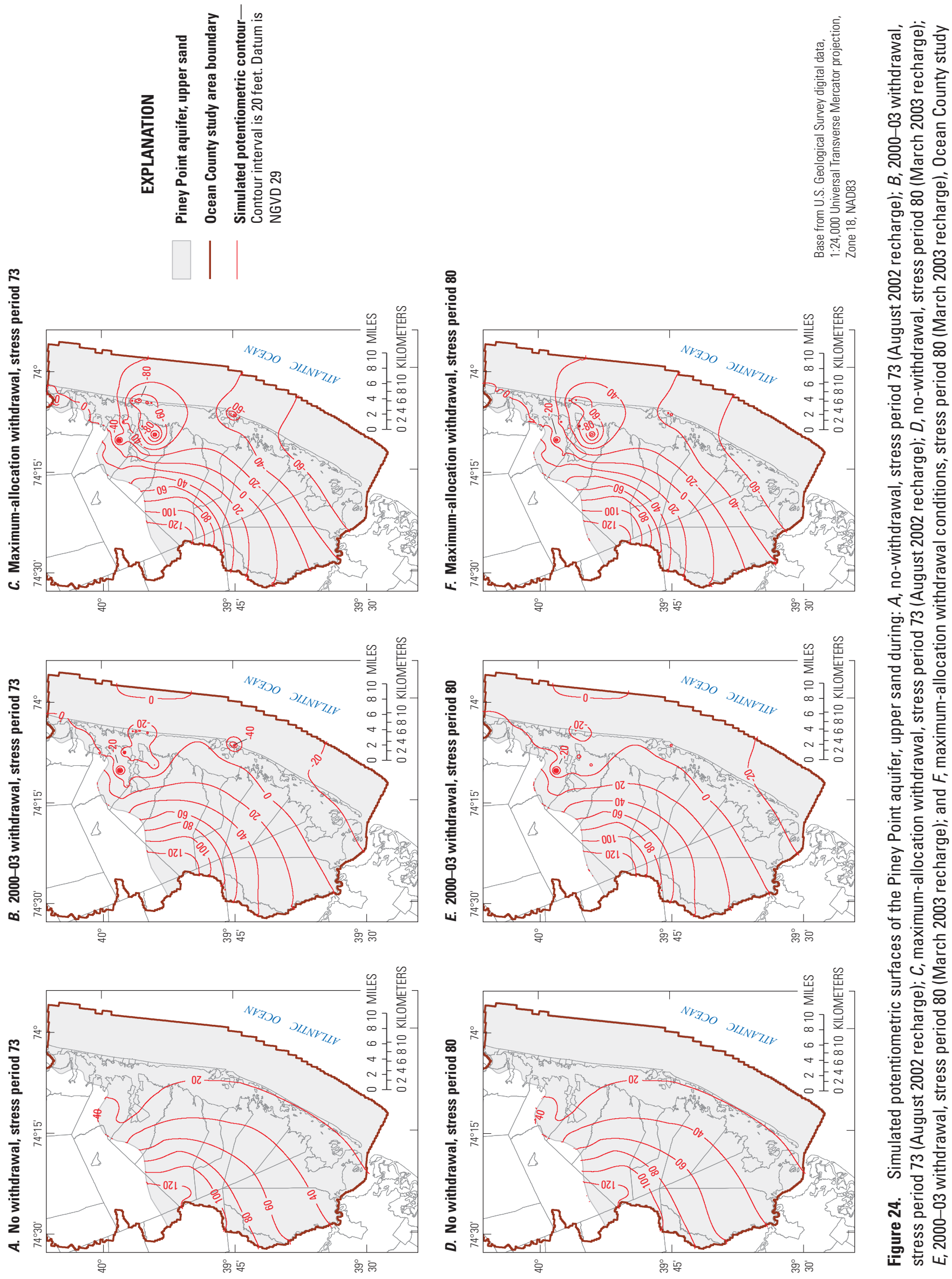

कू

흘 응 은

읃 으응

政 क

㐫离

号 $\overline{\frac{\pi}{3}} \cdot \frac{\mathrm{E}}{\mathrm{x}}$

む)

흠

단 은

등 드 흐

入े 인

음 음

‡ ह

i 들

๑)

元

के बे

는 홍음

등 인

응 용

吉产 离

응 告

茫示京

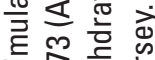

क 흥ㅎㅀ

ปั่

늠 ฏ 응 
conditions are at an altitude of approximately 20 feet on much of Long Beach Island (fig. $24 A$ and $D$ ). Cones of depression located in Toms River Township, Seaside Heights and Seaside Park Boroughs, and Barnegat Light Borough developed in the aquifer in response to 2000-03 groundwater withdrawals. Regional water levels in the Piney Point aquifer, upper sand, simulated for 2000-03 withdrawal conditions are at an altitude of -20 feet in the barrier island communities of southern Long Beach Township, Barnegat Light Borough, and Seaside Park Borough and the mainland communities of Berkeley Township, Ocean Gate Borough, and Toms River Township during stress period 80 (fig. 24E). Water levels lower than -20 feet are simulated at individual withdrawal wells. During stress period 73, the cones of depression expand and deepen, particularly in Barnegat Light Borough and the bay side of Toms River Township, Berkeley Township, and the barrier island communities of Seaside Park Borough north to Lavallette Borough (fig. 24B). As a result of 2000-03 withdrawals, the simulated potentiometric surface of the Piney Point aquifer, upper sand, exhibits regional drawdowns ranging from 40 to 60 feet in Little Egg Harbor Township, Tuckerton and Beach Haven Boroughs, southern Long Beach Township, Barnegat Light Borough, and the northern communities of Berkeley Township, Ocean Gate Borough, Toms River Township, and Seaside Heights and Seaside Park Boroughs during stress period 73. Individual wells may exhibit larger drawdowns than are simulated regionally (fig. 22D).

\section{Maximum-Allocation Withdrawal Conditions}

Simulation of maximum-allocation withdrawal conditions incorporate maximum permitted monthly withdrawals at all large volume withdrawal wells in the study area for the 2000 to 2003 analysis period. Maximum-allocation withdrawals in all aquifers are greater than 2000-03 withdrawals (fig. 25).

Analysis of selected stress periods indicates that groundwater withdrawals ( 45 to $63 \mathrm{ft}^{3} / \mathrm{s}$ ) during simulations of maximum-allocation withdrawal conditions affected net flow to constant head cells (94 to $124 \mathrm{ft}^{3} / \mathrm{s}$ ) and increased the net flow out of the Kirkwood-Cohansey aquifer system to the lower confined aquifers ( 52 to $70 \mathrm{ft}^{3} / \mathrm{s}$ ). Net flow out to drain and river cells (404 to $985 \mathrm{ft}^{3} / \mathrm{s}$ ) is reduced from 2000-03 flows. Increased withdrawals from the Rio Grande waterbearing zone in this simulation ( 0.6 to $\left.1.5 \mathrm{ft}^{3} / \mathrm{s}\right)$ are supported by a net increase of flow from other layers $\left(0.9\right.$ to $\left.1.5 \mathrm{ft}^{3} / \mathrm{s}\right)$. Increased withdrawals from the Atlantic City 800 -foot sand ( 22 to $43 \mathrm{ft}^{3} / \mathrm{s}$ ) produced more net flow into the aquifer from other layers ( 27 to $33 \mathrm{ft}^{3} / \mathrm{s}$ ). The Piney Point aquifer had more net flow into the aquifer from other layers $\left(7.2\right.$ to $\left.8 \mathrm{ft}^{3} / \mathrm{s}\right)$ during the maximum-allocation withdrawal simulation than during 2000-03 withdrawal conditions (fig. 25).

Comparison of simulations of no-withdrawal, 2000-03 withdrawal, and maximum-allocation withdrawal conditions reveals the effect of these conditions on base flow in streams in the Ocean County study area. Simulations of maximum-allocation withdrawals indicate that lower base-flows than those simulated for 2000-03 withdrawals occur at all streamflow-gaging stations, except Wrangel Brook at Mule Road near Toms River, N.J. (01408592) (fig. 26; table 11).

A comparison of base flow from simulations of nowithdrawal and maximum-allocation conditions reveals as much as a 20-percent reduction in base flow at individual streamflow-gaging stations from maximum-allocation withdrawals (table 11). The largest reduction in simulated base flow at streamflow-gaging stations due to maximum-allocation groundwater withdrawals occurs in the Toms River Basin. Simulated base flow in the Toms River at streamflow-gaging station Toms River near Toms River, N.J. (01408500), decreases by 15 to $20 \mathrm{ft}^{3} / \mathrm{s}$ from no-withdrawal conditions to maximum-allocation withdrawal conditions. This is the largest stream basin in the study area and is one of the most developed areas of Ocean County. These factors, combined with a large number of wells screened in the unconfined KirkwoodCohansey aquifer system, produced the large base-flow decline. Streamflow-gaging station Mill Creek near Manahawkin, N.J. (01409150), had the largest percent reduction in base flow between the two simulations, ranging from 11 to 20 percent. Three of the 12 streamflow-gaging stations in the Ocean County study area had average base-flow reductions of less than $1 \mathrm{ft}^{3} / \mathrm{s}$ from no-withdrawal to maximum-allocation conditions (table 11). The smallest average reduction in simulated base flow from no-withdrawal conditions to maximumallocation withdrawal conditions $\left(0.18 \mathrm{ft}^{3} / \mathrm{s}\right)$ occurred at Cedar Run near Manahawkin, N.J. (01409250); the drainage basin of this stream is one of the smallest, least developed stream basins in the study area and contains few production wells.

To avoid measuring tidal fluctuations, streamflow-gaging stations are located within 8 miles upstream from the area where their streams discharge into the Barnegat Bay-Little Egg Harbor estuary. Gages are primarily on relatively large stream reaches; numerous streams or reaches that flow into the Barnegat Bay-Little Egg Harbor are ungaged. The combined effect of withdrawals on both gaged and ungaged streams is summarized by the total base-flow reduction to the Barnegat Bay-Little Egg Harbor estuary (table 12). Compared with the no-withdrawal simulation, maximum-allocation withdrawals reduce the total simulated base flow to the Barnegat Bay-Little Egg Harbor estuary by $64 \mathrm{ft}^{3} / \mathrm{s}$ (20 percent) during stress period 64 (November 2001 recharge) and by $78 \mathrm{ft}^{3} / \mathrm{s}$ (10 percent) during stress period 77 (December 2002 recharge).

Simulated maximum-allocation groundwater levels at wells 29-141, 29-513, and 29-1060, screened in the KirkwoodCohansey aquifer system, had additional drawdown of less than 1 foot (fig. 19A, $B$ and $C$ ) from 2000-03 water levels. Simulated 2000-03 water levels in well 29-17, located in Barnegat Light Borough, decrease an additional 15-17 ft from those simulated under maximum-allocation withdrawal conditions (fig. 19D).

Analysis of simulation results of maximum-allocation withdrawal conditions indicate water levels decrease 

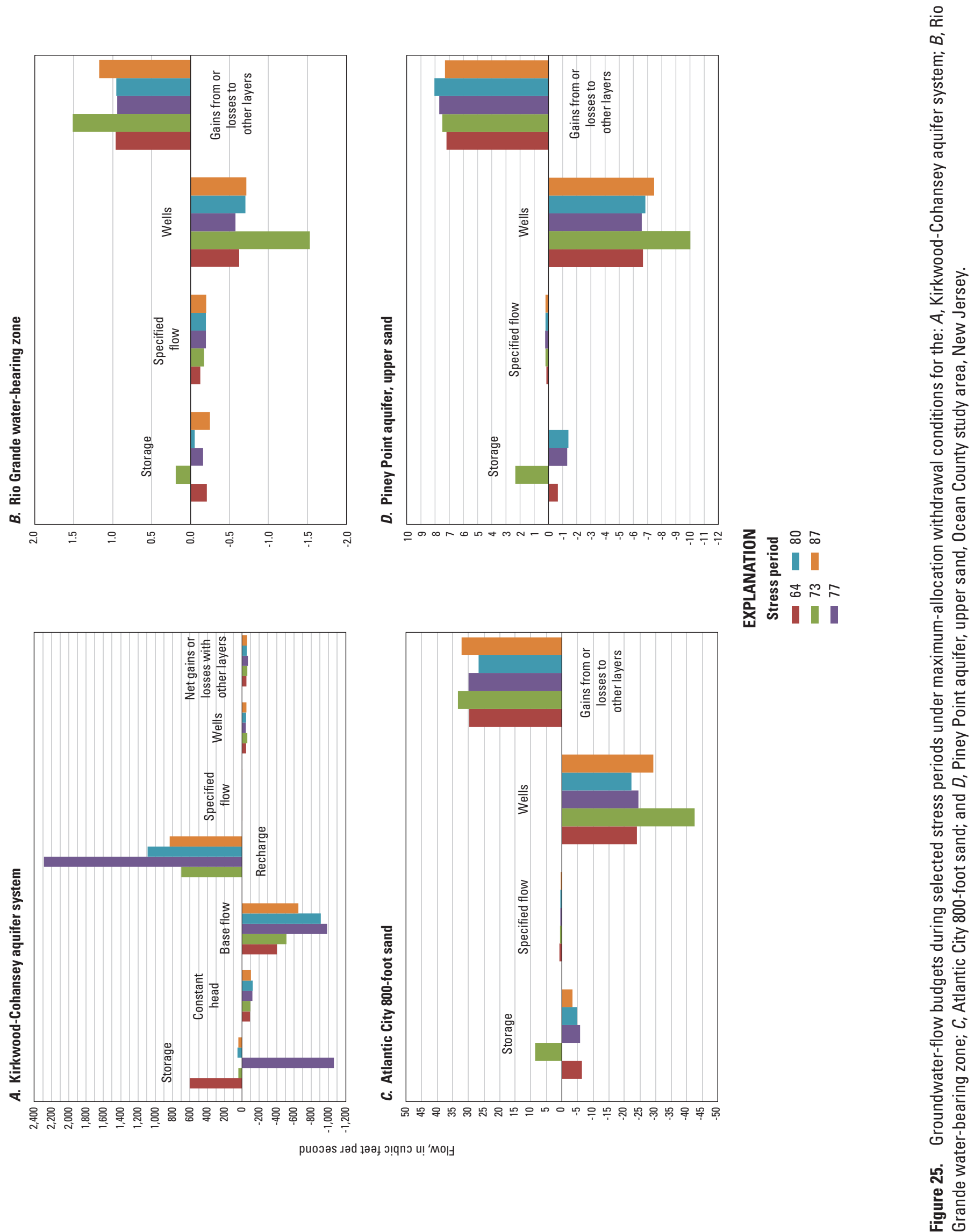

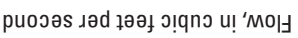



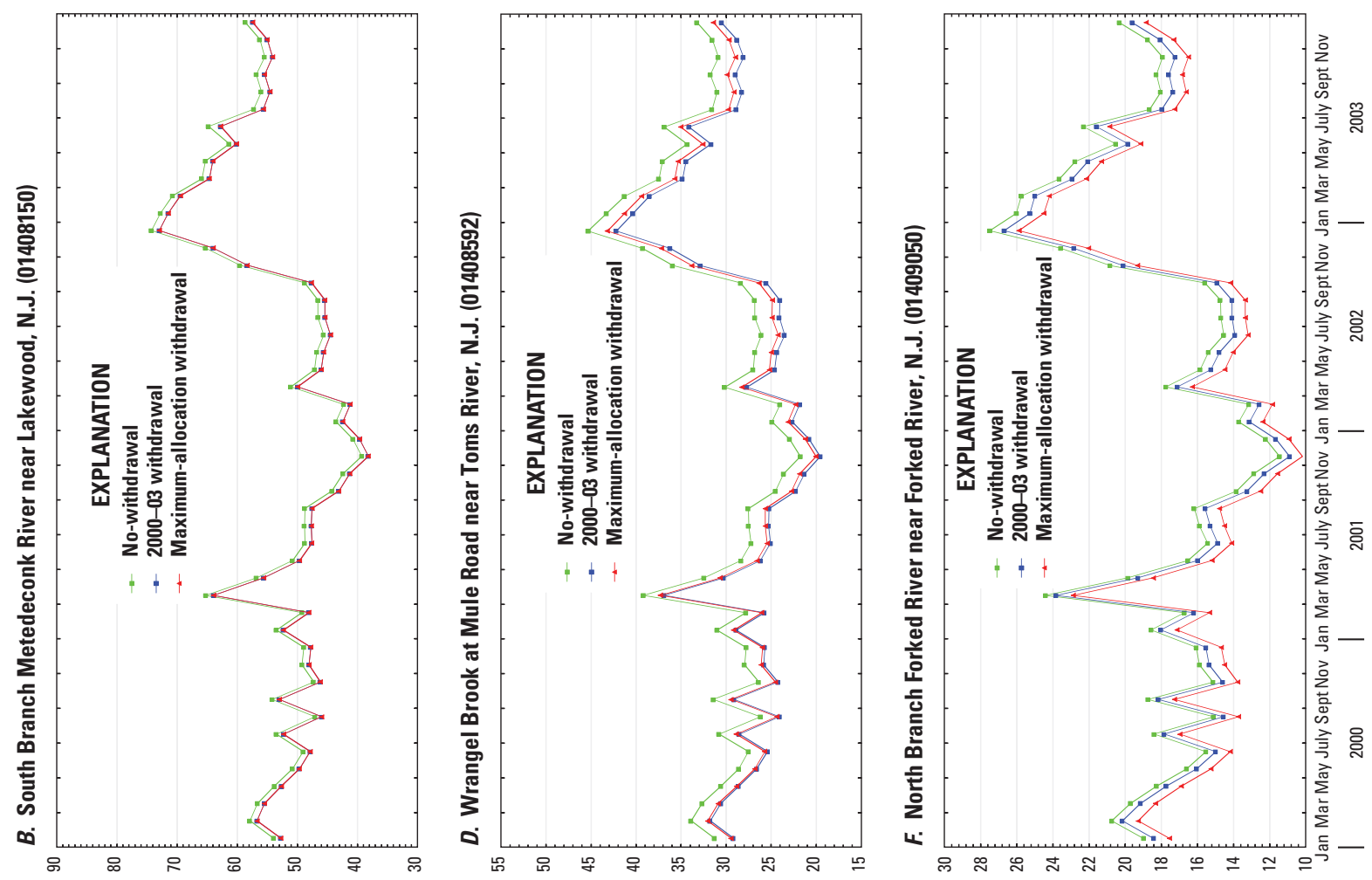

产

뭉

c。导跑

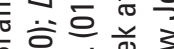

产完㐫

웡 恙

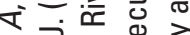

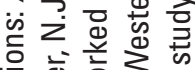

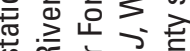

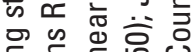

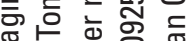

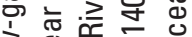

은

这蓄

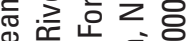

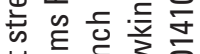

牙语

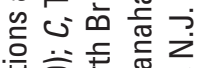

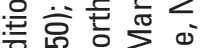

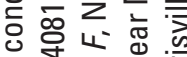

웡ㅎㅇ

究

立守克

3원

든추응

웡후융

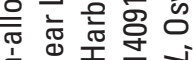

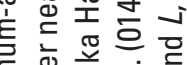
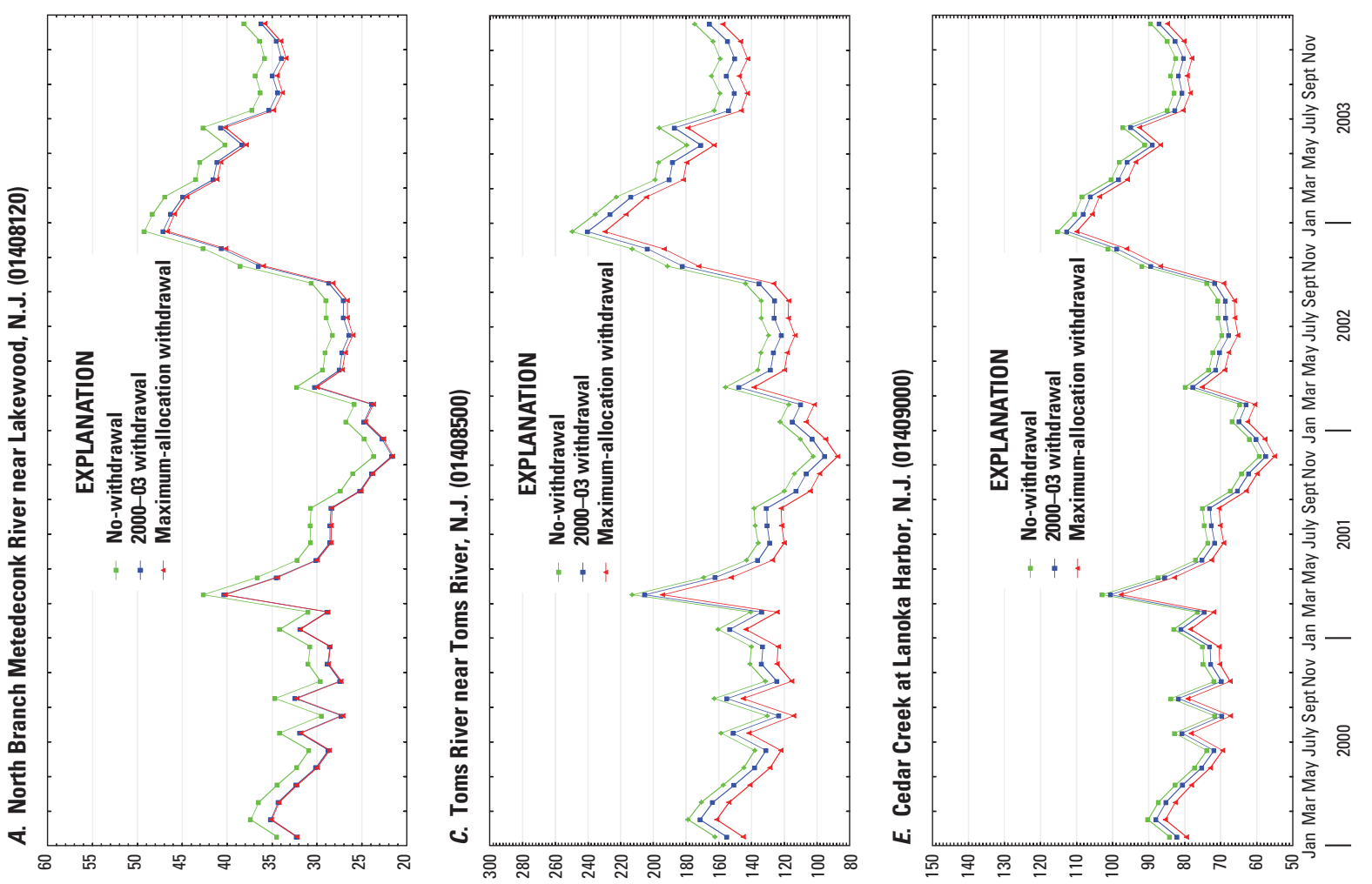

言究完完

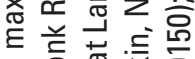

드웛

웡

元 $\sum^{\frac{1}{\pi}} \frac{\pi}{0} \sum^{\frac{\pi}{2}}$

등 đ

उ山屺声

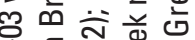

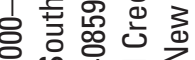

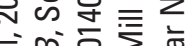

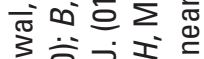

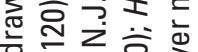

흥 흥ㅎㅁ

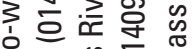

구요

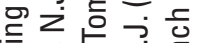

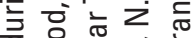

उ号完

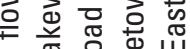

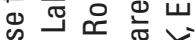

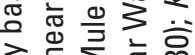

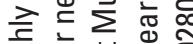

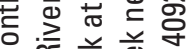

产立前离守

ง่

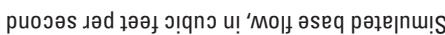

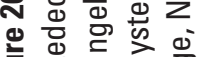

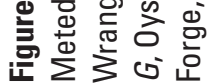



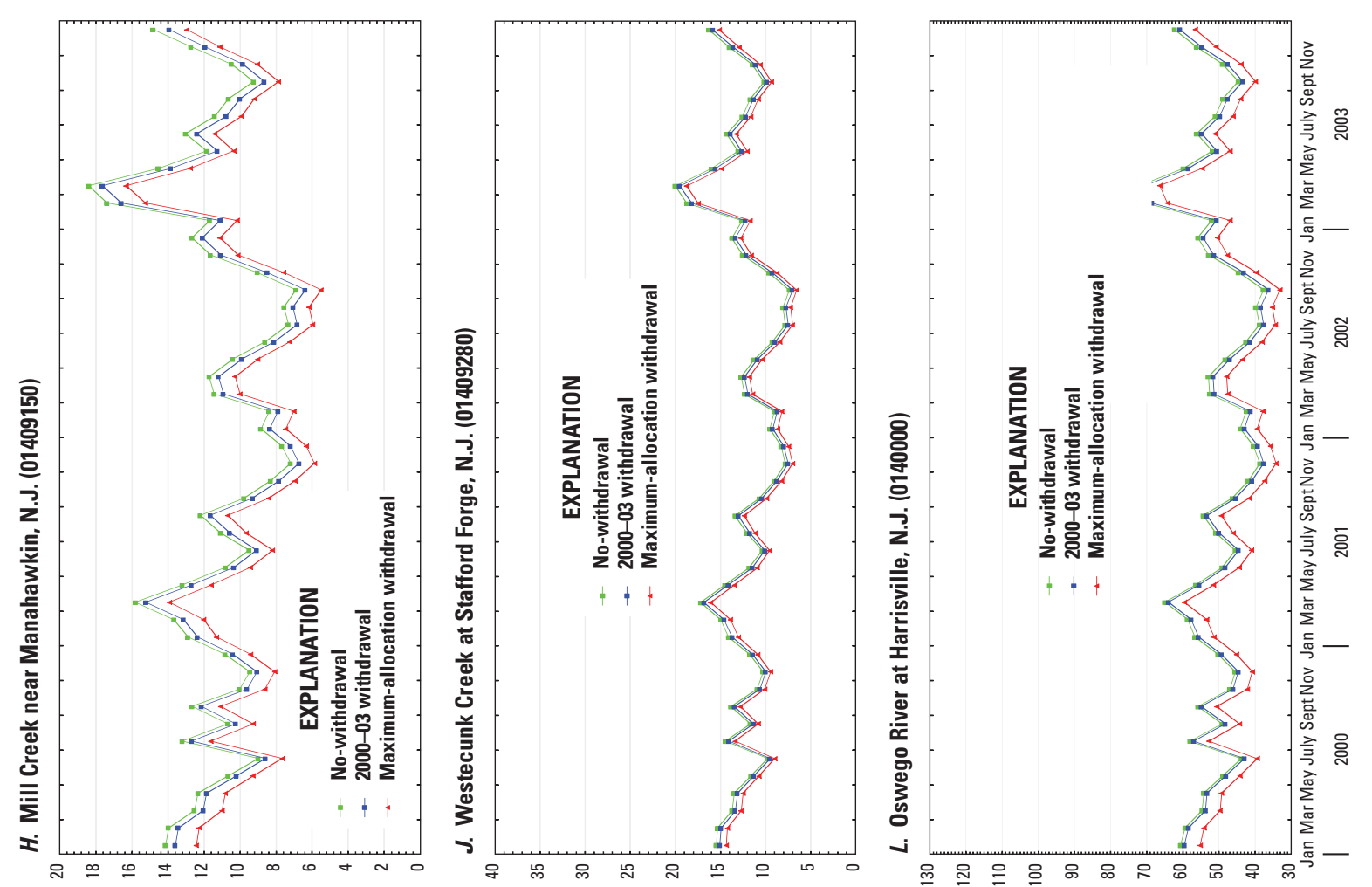

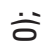

닐

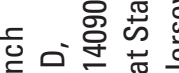

뜬 흐은

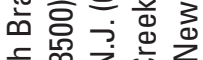

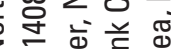

2 을

is خ व

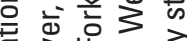

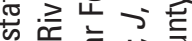

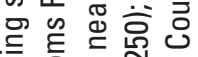

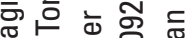

히웡

공흥ㅇㅇㅇ

产 㐫客

잉 훈ㅇㅇㅇ

离告宁言告

하의 진

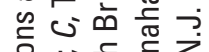

을 立든

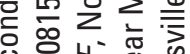

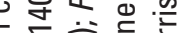

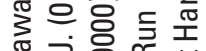

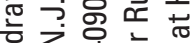

考它要

3엉 웜

흐 z

ॐ

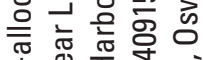

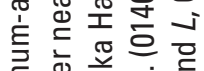
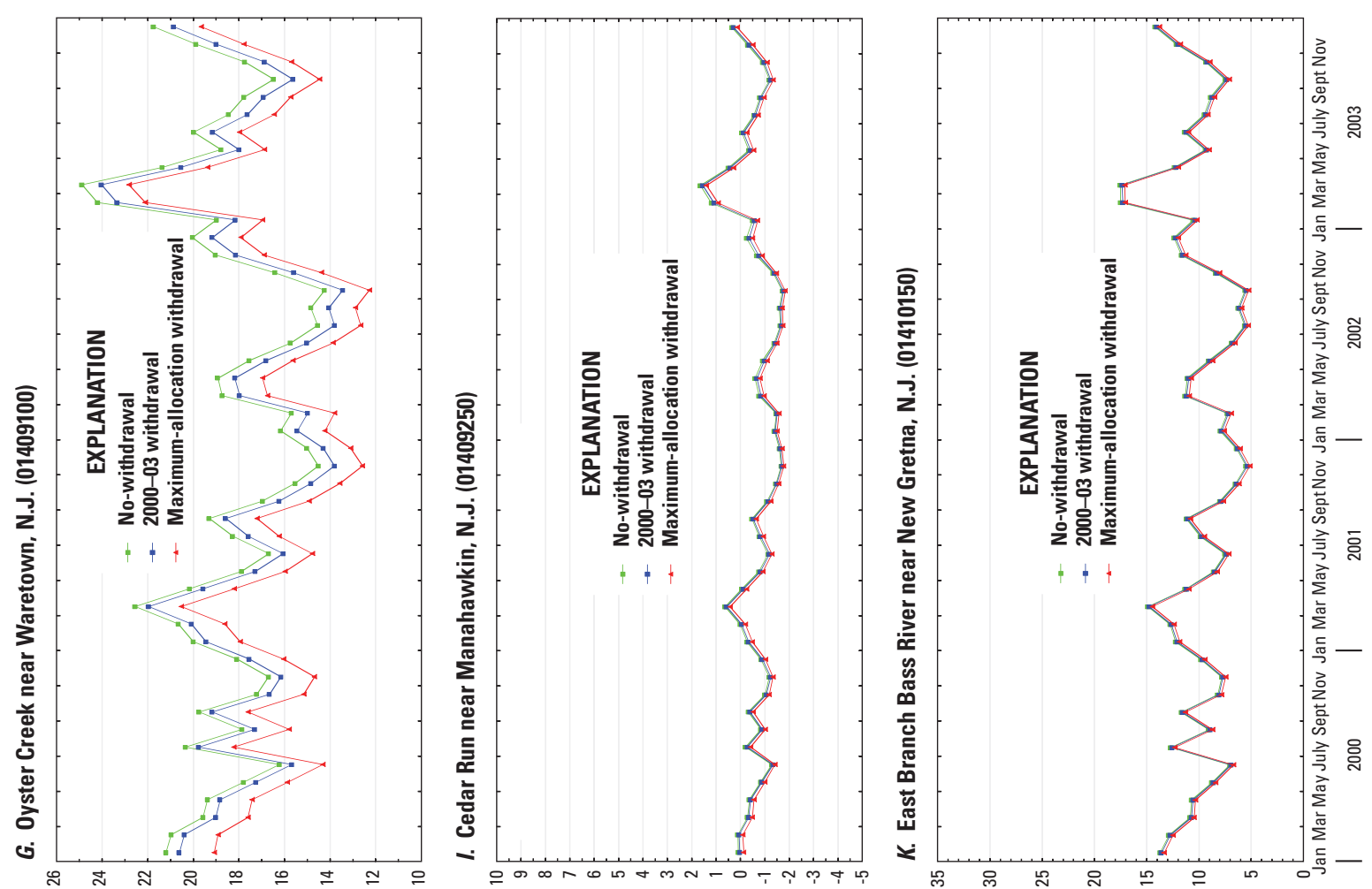

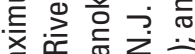

希嵒文

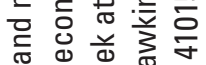

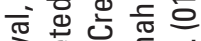

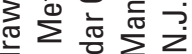

흔 덩

了 띤

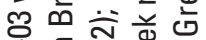

옹 志总

웅 क o

完败正文

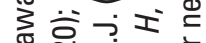

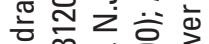

둥ㅎㅇ응 웅

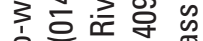

누요

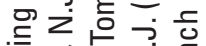

它放元

के ळे

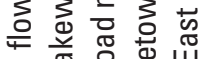

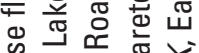

政造方

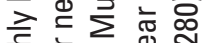

贲这䒕导

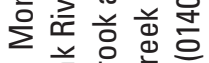

ง.

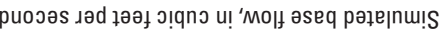

ஸें

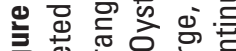

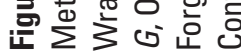


substantially from simulated no-withdrawal water levels in the Rio Grande water-bearing zone (fig. $21 C$ and $F$ ). Regional water levels in the Rio Grande water-bearing zone range from an altitude of -30 feet in Harvey Cedars Borough to -60 feet in Little Egg Harbor Township and Beach Haven Borough during stress period 80 of simulated maximum-allocation withdrawal conditions. The simulated cone of depression centered at Holgate deepens during stress period 73 with a regional water level altitude of -80 feet in Little Egg Harbor Township and Beach Haven Borough. Regional drawdowns of the no-withdrawal potentiometric surface in the Rio Grande water-bearing zone range from 0 to 20 feet near the northern extent of the aquifer to 100 to 120 feet in the southern coastal communities from maximum-allocation withdrawal conditions during stress period 73 (fig. 27A). Simulated drawdown at public-supply well 29-1621 in Holgate is larger than the regional drawdown (fig. 27A).

Regional water levels in the Atlantic City 800-ft sand, upper sand, simulated for maximum-allocation withdrawal conditions, range from an altitude of -20 feet at the southern end of Island Beach State Park in Ocean Township, to -80 feet at Surf City Borough and extend through the southern end of

\section{A. Rio Grande water-bearing zone}

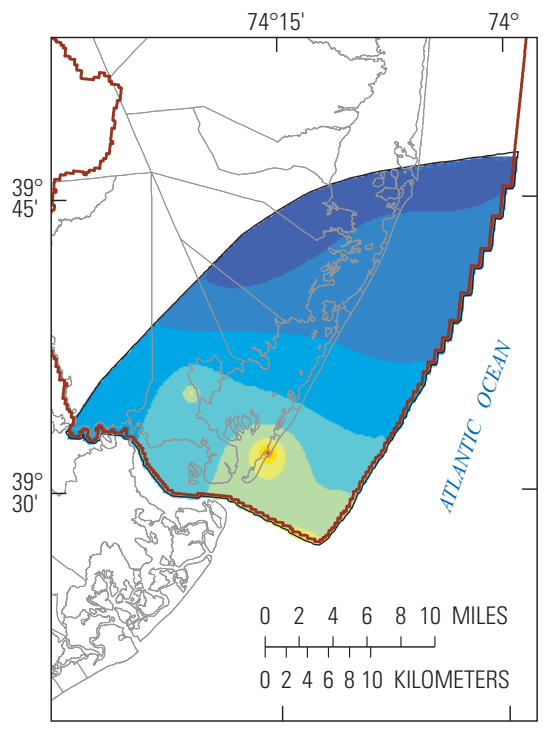

C. Atlantic City 800 -foot sand, lower sand

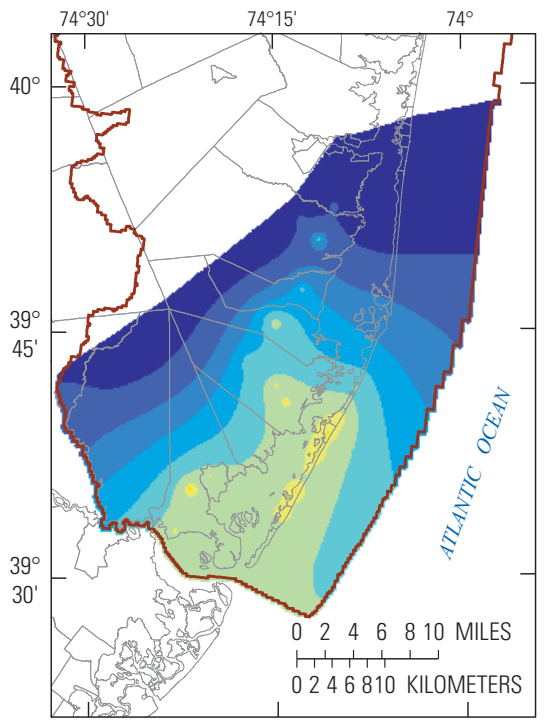

\section{B. Atlantic City 800 -foot sand, upper sand}

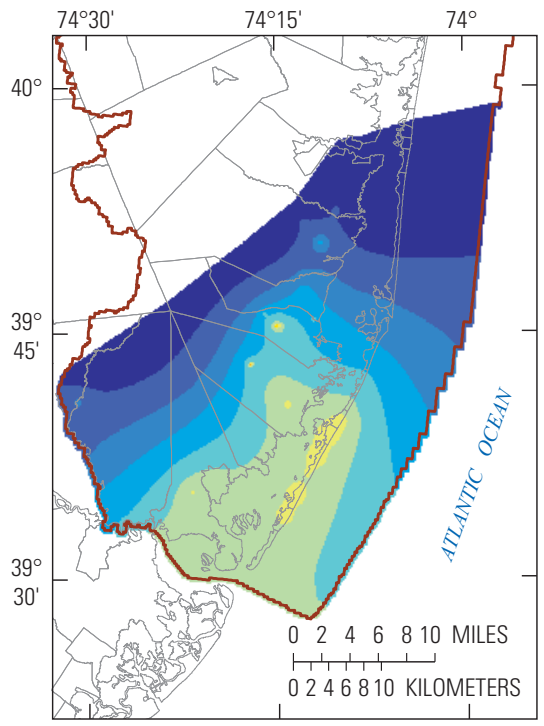

D. Piney Point aquifer, upper sand

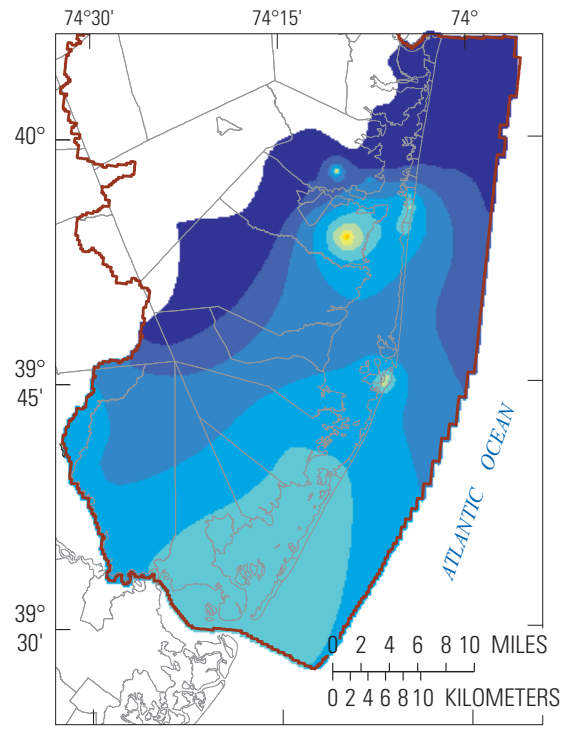

EXPLANATION

Simulated drawdown from no withdrawal to maximum-allocation withdrawal conditions, in feet

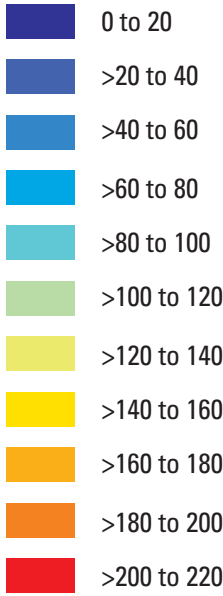

— Ocean County study area boundary

Base from U.S. Geological Survey digital data 1:24,000 Universal Transverse Mercator projection, Zone 18, NAD83

Figure 27. Simulated drawdown of potentiometric surfaces of the: $A$, Rio Grande water-bearing zone; $B$, Atlantic City 800-foot sand, upper sand; $C$, Atlantic City 800-foot sand, lower sand; and $D$, Piney Point aquifer, upper sand from no-withdrawal to maximumallocation withdrawal conditions, stress period 73 (August 2002), Ocean County study area, New Jersey. 
Simulated Effects of Groundwater Withdrawals From Aquifers in Ocean County and Vicinity, New Jersey

Long Beach Island and Little Egg Harbor Township during stress period 80 (fig. $23 F$ ). During stress period 73 the cone of depression expands further inland and deepens to -100 feet at Surf City Borough south to Beach Haven Township (fig. 23C). Drawdown from no-withdrawal groundwater levels in the Atlantic City 800-foot sand aquifer, upper and lower sands, resulting from maximum-allocation withdrawals indicate a large area of water-level declines. Simulation of maximumallocation withdrawals during stress period 73 indicates regional drawdowns from simulated no-withdrawal water levels in the Atlantic City 800-foot sand of 100 to 120 feet centered along Long Beach Island, and as much as 120 to 140 feet in the center of the cone of depression (figs. $27 B$ and $C$ ).

Initial simulated no-withdrawal groundwater levels in the Piney Point aquifer, upper sand, on Long Beach Island are near an altitude of 20 feet (figs. $24 A$ and 24D). The simulated maximum-allocation potentiometric surfaces of the Piney Point aquifer, upper sand, during stress periods 73 and 80 indicate the expansion of several cones of depression that developed during 2000-03 withdrawal conditions. The progression of a regional depression in the potentiometric surface of the Piney Point aquifer, upper sand that parallels the coast is best noted by examining the $-20-\mathrm{ft}$ contour for both stress periods. The -20-ft contour extends in the north from Lavallette Borough and Toms River Township south and westward through all of the bay-side communities, including Little Egg Harbor and Bass River Townships at the southern boundary (fig. 24B, $24 C, 24 E$, and 24F). The potentiometric surface of the Piney Point aquifer for both stress periods appear to be similar with the exception of additional drawdowns at several withdrawal wells during stress period 73. Analysis of stress period 73 indicates that 80 to 100 feet of drawdown of the simulated no-withdrawal Piney Point, upper sand potentiometric surface occurred in the communities of Berkeley and Toms River Townships, Seaside Heights, Seaside Park and Barnegat Light Boroughs, and southward from Surf City Borough and Stafford Township; as a result of maximum-allocation withdrawals, larger drawdowns occur at withdrawal wells than within the regional potentiometric surfaces (fig. 27D).

\section{Simulated Groundwater Flow Paths and Travel Time}

Production wells on the mainland or the barrier island that are close to the shoreline may be susceptible to saltwater intrusion from recharge that originates beneath the Atlantic Ocean or beneath Barnegat Bay-Little Egg Harbor. To evaluate the vulnerability of these wells to saltwater intrusion, MODFLOW simulations are analyzed by using the particletracking code MODPATH (Pollock, 2012) to determine the source and travel time of water flowing to the production wells. Two steady-state groundwater-flow models that simulate 2000-03 and maximum-allocation withdrawal conditions are described in this section. For the 2000-03 withdrawal conditions (scenario 1), annual average groundwater withdrawals from 2000 to 2003 are used. Annual average maximum-allocation groundwater withdrawals are used to simulate maximumallocation conditions (scenario 2). Groundwater withdrawals are simulated with the MODFLOW Well package. Both steady-state groundwater-flow models incorporated annual average recharge in the Ocean County study area for 2000 to 2003. MODPATH estimates groundwater flow paths, travel times, and recharge locations of the groundwater-flow system in the study area. Simulated heads for each model layer and cell-by-cell budget files derived from individual MODFLOW simulations are input to MODPATH to calculate particle paths and travel times.

The effective porosity of each model layer is used in the calculation of travel time. Effective porosity is set to 0.30 for the unconfined Kirkwood-Cohansey aquifer system and from 0.35 to 0.40 for all confining units and confined aquifers.

These porosities are typical for the type of geologic materials that compose the aquifers and confining units in the study area (Freeze and Cherry, 1979) and are similar to values used in other studies of the unconfined Kirkwood-Cohansey aquifer system (Kauffman and others, 2001) and the Atlantic City 800 -foot sand in the New Jersey Coastal Plain (Voronin and others, 1996).

Particles of water are simulated as originating within cells that represent the screen interval of wells in the KirkwoodCohansey aquifer system, the Rio Grande water-bearing zone, or Atlantic City 800-foot sand; the particles are tracked backward to the point where they entered the simulated aquifer system. The wells used in this analysis are chosen from the USGS GWSI database. Wells are restricted to withdrawal wells with screen intervals in the aquifers and model layers of interest. For the Kirkwood-Cohansey aquifer system, only the model cells that contain an existing well within 1 mile of the shoreline are selected (fig. 28). An internal array of 27 particles is used for each cell where particles originated. This analysis is useful for determining the probable recharge area for water withdrawn from each well. Particles that enter a cell that behaves as a weak sink are allowed to pass through the cell.

The Barnegat Bay-Little Egg Harbor estuary, Great Bay, Atlantic Ocean, and coastal wetlands on the barrier island and mainland are important hydrologic boundaries. Groundwater withdrawals could reverse the direction of flow, with the possible effects of reducing freshwater discharge to tidal systems, thus affecting the coastal ecosystem, and inducing saltwater into freshwater aquifers, thus damaging the drinking-water resource. To show areas of simulated groundwater discharge into the bay from the groundwater system and areas of recharge to the aquifer beneath the bay or ocean, the net value of flow for each constant-head model cell in layer 1 is mapped (fig. 9). The pattern and quantity of flow from or to constant head boundaries show where groundwater withdrawals from wells in near-shore areas affect groundwater flow to and from the saltwater boundaries. 


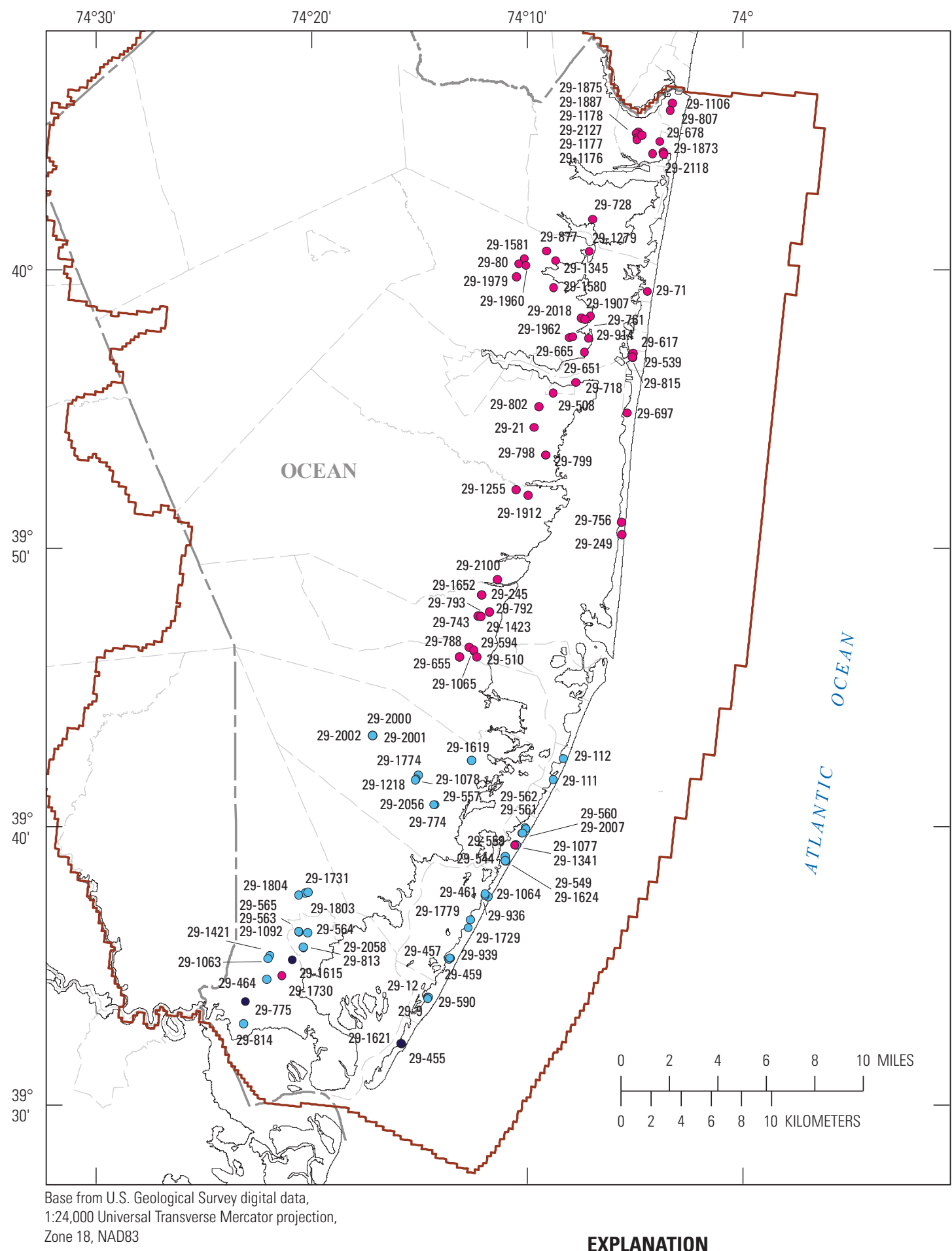

- Ocean County study area boundary

Well, by aquifer and identification number

- Kirkwood-Cohansey aquifer system

- Rio Grande water-bearing zone

Atlantic City 800-foot sand

Figure 28. Locations of selected wells screened in the Kirkwood-Cohansey aquifer system proximal to the coastline and production wells screened in the Rio Grande water-bearing zone or in the Atlantic City 800-foot sand, used in particle-tracking analysis, Ocean County study area, New Jersey. 


\section{Scenario 1}

For scenario1, average 2000-03 hydrologic stresses are simulated by incorporating average recharge and withdrawals for the years 2000 through 2003. This approach identifies which wells may be susceptible to saltwater intrusion from recharge of salty water originating in Barnegat Bay-Little Egg Harbor or the Atlantic Ocean. Flow to near-shore Kirkwood-Cohansey aquifer system wells is determined by using MODPATH to track particles backward from the model layer of each well screen to their origin at the water table or point of recharge. The travel time for each flow path is determined by MODPATH, which provides an approximate age of groundwater at a particular well. The same approach is used to track particles backward from the model layer of the well screen for wells that withdraw water from the Rio Grande water-bearing zone and the Atlantic City 800-foot sand.

Travel times of most flow paths to Kirkwood-Cohansey aquifer system wells, range from 11 years to nearly 50,700 years (fig. 29). A flow path that originates at the model boundary in the ocean east of Seaside Heights Borough has a travel time greater than 1.35 million years. Most near-shore wells screened in the Kirkwood-Cohansey aquifer system derive water from updip sources inland. However, wells located on Island Beach, particularly in the community of Seaside Heights Borough, have some flow paths that start beneath Barnegat Bay or the Atlantic Ocean and are susceptible to saltwater intrusion. Travel times of the shortest flow paths to wells on Island Beach indicate that it could take slightly less than 350 years for water entering the aquifer system in this area to reach these wells. Other flow paths to these wells have travel times that are substantially longer than 350 years; for example, as much as 10,400 years in Seaside Heights Borough. A well on the barrier island portion of Berkeley Township, just south of Seaside Park Borough has flow paths that do not extend past the island. Wells located in Island Beach State Park (fig. 2), within Berkeley Township, have flow paths that extend inland to central Berkeley Township, indicating that the wells are not susceptible to saltwater intrusion. Travel times of flow to these wells range from approximately 4,700 to 7,800 years.

Flow paths from recharge areas to wells screened in the Rio Grande water-bearing zone and Atlantic City 800-foot sand (fig. 30) have longer travel times than flow paths to wells in the Kirkwood-Cohansey aquifer system; the Rio Grande water-bearing zone and Atlantic City 800 -foot sand aquifers are greater in depth than the Kirkwood-Cohansey aquifer system and flow paths in the Rio Grande water-bearing zone and Atlantic City 800 -foot sand aquifers typically traverse low permeability hydrogeologic units that greatly retard the velocity of flow- two circumstances that may substantially affect travel times. Travel times along flow paths from point of recharge to production wells range from nearly 530 to greater than 3.73 million years.

Most of the wells screened in the Rio Grande waterbearing zone and the Atlantic City 800 -foot sand derive a large amount of their recharge from the Oswego River Basin area (fig. 30). Wells located on the barrier island have several flow paths that originate beneath Barnegat Bay and several that originate offshore, east of the well or beneath the ocean adjacent to the eastern boundary of the study area. Travel time of the flow paths that originate beneath Barnegat Bay-Little Egg Harbor or offshore of the southern part of Long Beach Island are estimated to be between nearly 19,000 and 517,000 years. Flow paths that end at the study area boundary would likely extend eastward if the boundary extended farther out in the ocean than it does in these model simulations. Travel times for these paths are estimated to be between nearly 2,900 years and 3.73 million years; however, they originate in model layer 5 or 9 and are not in contact with present-day saline ocean water. This analysis indicates that, under 2000-03 pumping regimes, the water quality in these wells is not likely to be affected by saltwater intrusion in the foreseeable future. In addition, the salinity and age of water derived from these wells would consist of a blend of fresh and salty sources.

\section{Scenario 2}

For scenario 2, average maximum-allocation withdrawal conditions are simulated for each well, coupled with average yearly recharge during the period 2000 to 2003. Flows to near-shore Kirkwood-Cohansey aquifer system wells and to deeper confined Rio Grande water-bearing zone and Atlantic City 800 -foot sand wells are determined by tracking particles backward from wells to the points where water entered the groundwater-flow system (figs. 31 and 32). Scenario 2 illustrates how groundwater withdrawals greater than the 2000-03 withdrawals simulated in scenario 1 affect the flow of water to shallow near-shore and to relatively deep confined wells along the coast in the Ocean County study area. This approach indicates which wells may be susceptible to saltwater intrusion by deriving some of their recharge from salty water; the approach also yields estimates of the travel times of particles that are withdrawn at each well.

Results of scenario 2 indicate that wells screened in the Kirkwood-Cohansey aquifer system in Seaside Heights Borough and in the Island Beach State Park area of Berkeley Township have flow paths that start beneath the Barnegat Bay or the Atlantic Ocean (fig. 31). The travel time from recharge to discharge point for these particles is estimated to be approximately 400 to 12,000 years. This indicates that these wells are potentially susceptible to saltwater intrusion from maximumallocation groundwater withdrawals. A well in Ship Bottom Borough is also susceptible to an influx of saltwater along flow paths with travel times of approximately 140 to 7,400 years. Wells on the mainland have flow paths that originate farther inland and, thus, are not susceptible to saltwater intrusion.

Wells screened in the Rio Grande water-bearing zone or Atlantic City 800-foot sand have longer flow paths and travel times (fig. 32) than wells screened in the shallower, unconfined Kirkwood-Cohansey aquifer system (fig. 31). Most particles that flow to the confined wells on the mainland 


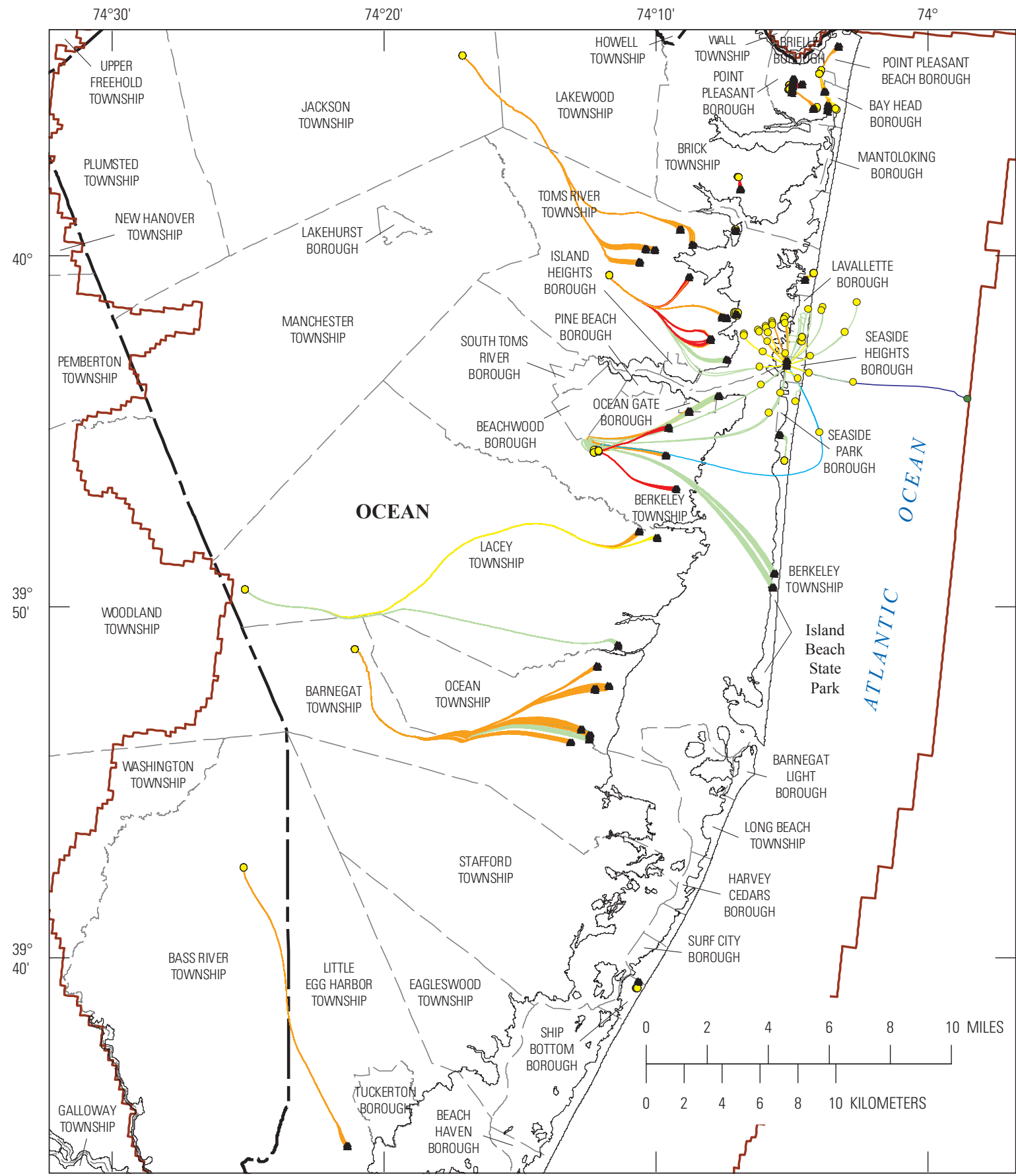

Base from U.S. Geological Survey digital data, 1:24,000 Universal Transverse Mercator projection, Zone 18, NAD83

EXPLANATION

Ocean County study area boundary

Travel time, in years

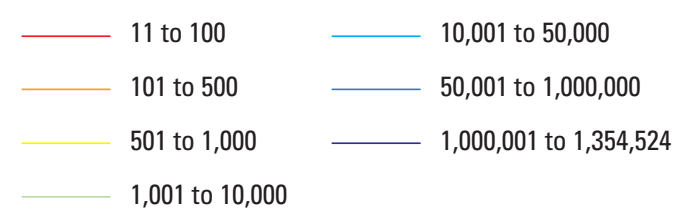

- Flow paths traced backward from wells to point of origin

Model layer of end points

○ 1

- 9

Figure 29. Flow paths from point of recharge to point of discharge and travel time of particles that discharge to near-shore wells screened in the unconfined Kirkwood-Cohansey aquifer system, average 2000-03 withdrawal conditions, 0cean County study area, New Jersey. 


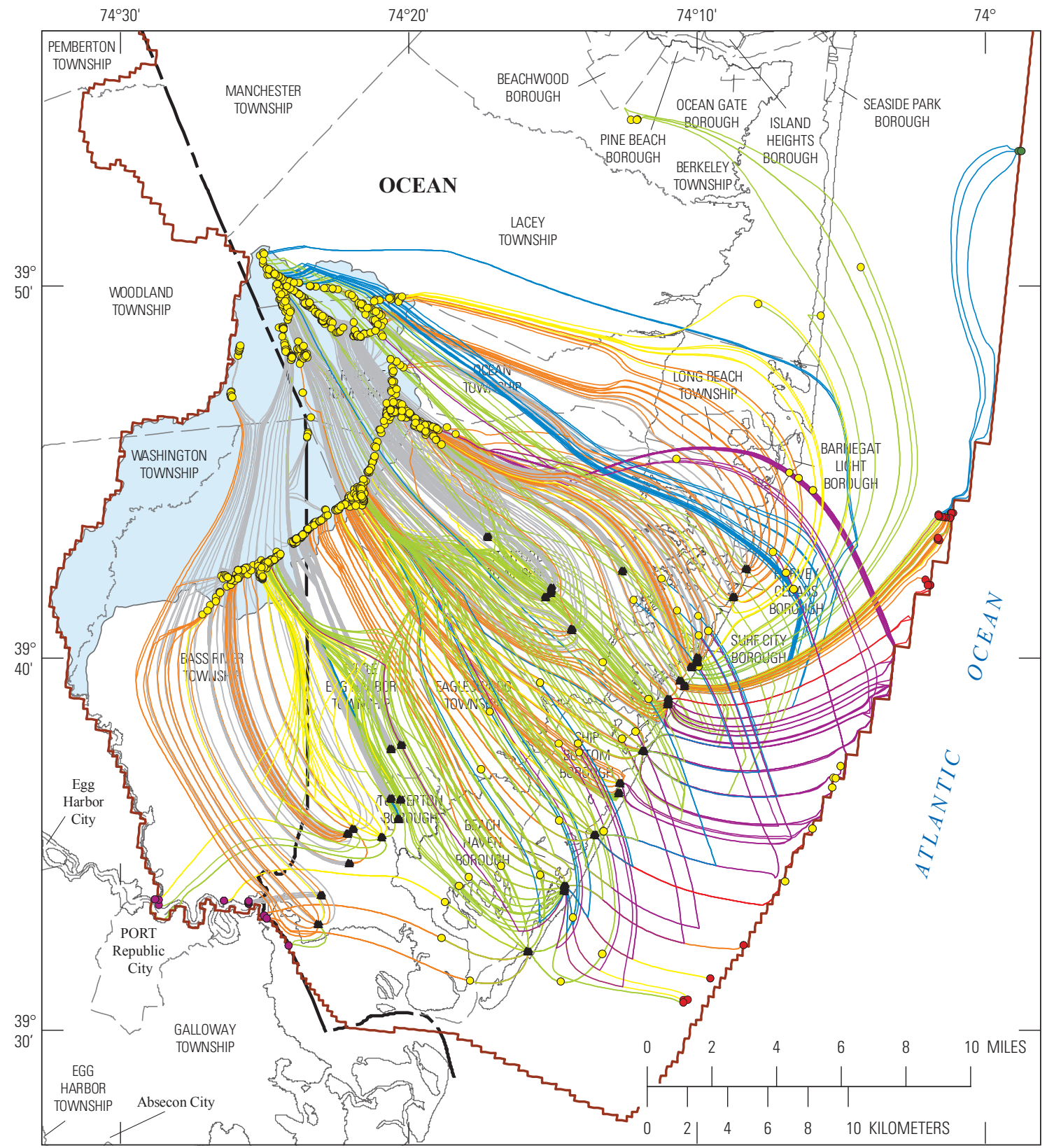

Base from U.S. Geological Survey digital data,

1:24,000 Universal Transverse Mercator projection,

Zone 18, NAD83

\section{EXPLANATION}

Travel time, in years

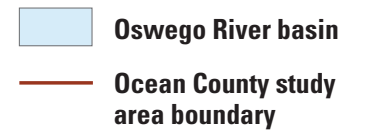
area boundary

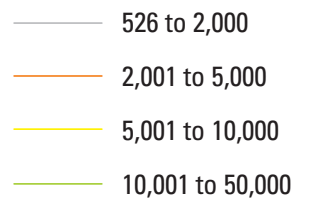

\section{- Flow paths traced backward from wells to point of origin}

Model layer of end points

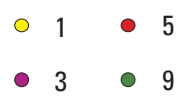

Figure 30. Flow paths from point of recharge to point of discharge and travel time of particles that discharge to wells screened in the Rio Grande water-bearing zone or the Atlantic City 800-foot sand, average 2000-03 withdrawal conditions, 0cean County study area, New Jersey. 


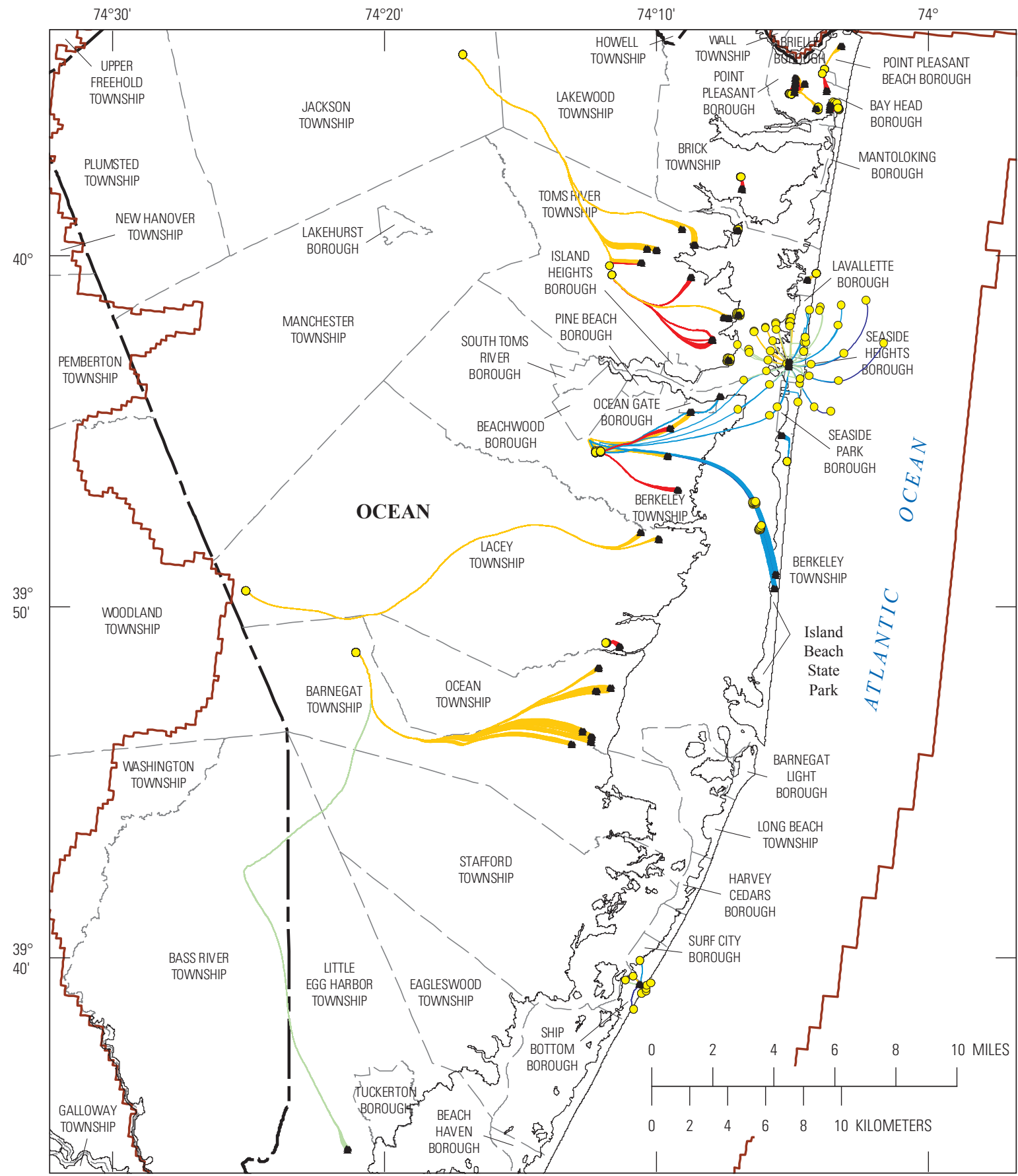

Base from U.S. Geological Survey digital data,

1:24,000 Universal Transverse Mercator projection, Zone 18 , NAD83

\section{EXPLANATION}

Ocean County study area boundary

Travel time, in years

19 to 200

2,001 to 5,000

201 to 600

5,001 to 12,021
- Flow paths traced backward from wells to point of origin

\section{Model layer of end points}

$\circ 1$

601 to 2,000

Figure 31. Flow paths from point of recharge to point of discharge and travel time of particles that discharge to near-shore wells screened in the unconfined Kirkwood-Cohansey aquifer system, average maximum-allocation withdrawal conditions, Ocean County study area, New Jersey. 


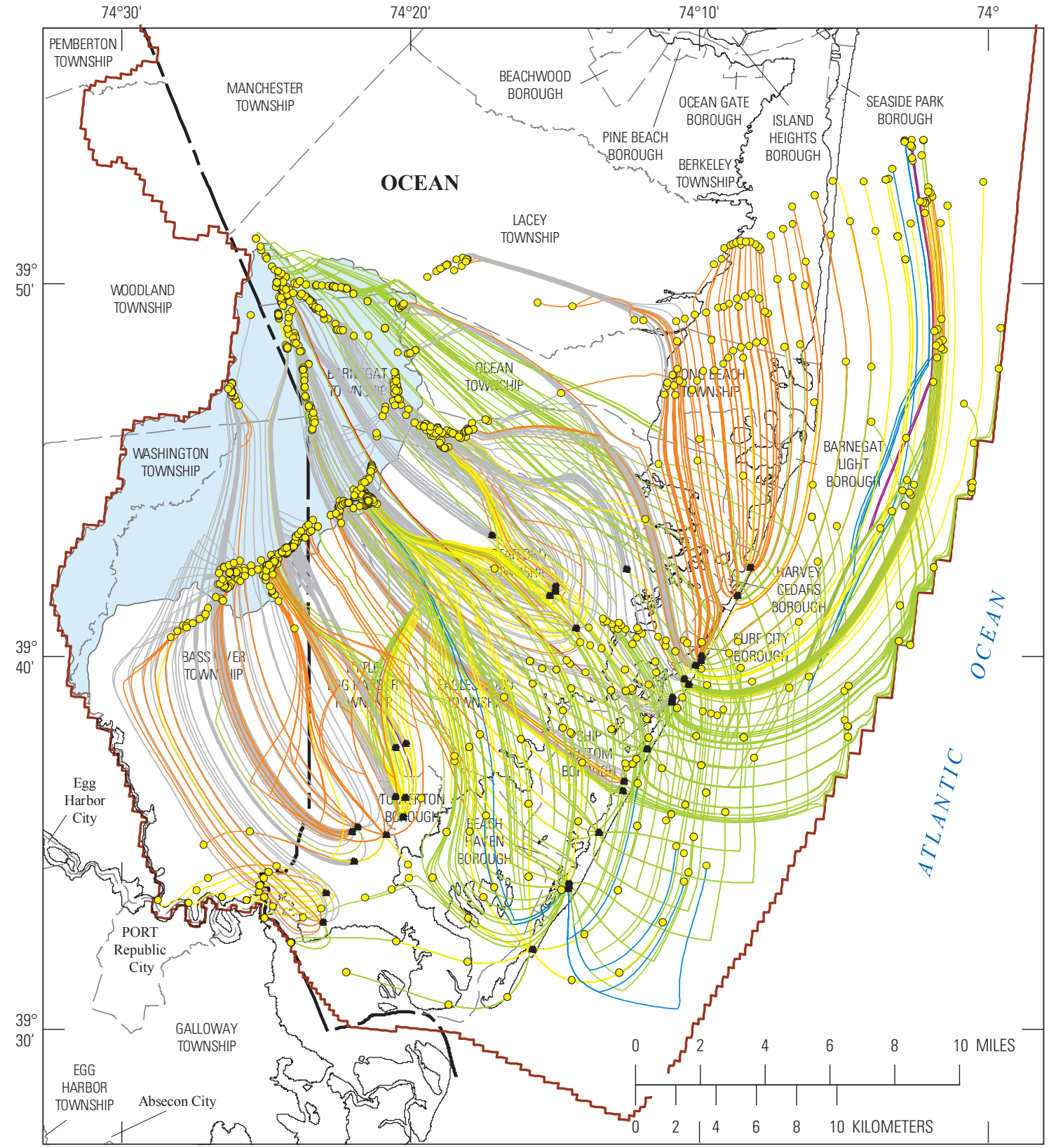

Base from U.S. Geological Survey digital data,

1:24,000 Universal Transverse Mercator projection,

Zone 18, NAD83

\section{EXPLANATION}

Travel time, in years Oswego River basin
Ocean County study
area boundary

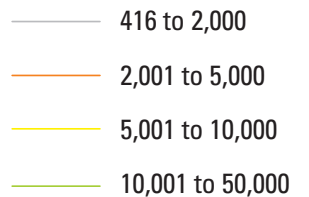

- Flow paths traced backward from wells to point of origin

Model layer of end points

- 1

Figure 32. Flow paths from point of recharge to point of discharge and travel time of particles that discharge to wells screened in the Rio Grande water-bearing zone or the Atlantic City 800-foot sand, average maximum-allocation withdrawal conditions, 0 cean County study area, New Jersey. 
originate in the Oswego River Basin (fig. 32). Travel times of water entering all Rio Grande water-bearing zone and Atlantic City 800-foot sand wells range from approximately 400 to 268,000 years. Wells in the communities of Harvey Cedars Borough, Surf City Borough, Ship Bottom Borough, Long Beach Township, and Beach Haven Borough on Long Beach Island have flow paths that originate in a combination of areas beneath the Barnegat Bay-Little Egg Harbor or the Atlantic Ocean, and on the mainland. Travel times of particles that start beneath either the Barnegat Bay-Little Egg Harbor or the Atlantic Ocean range from approximately 2,300 to 134,000 years.

\section{Groundwater Flow to Saltwater Boundaries}

Flow from the groundwater system into and out of Barnegat Bay-Little Egg Harbor serves to maintain the ecosystem of the estuary and to determine the potential for saltwater intrusion into the groundwater system. The net flux of bay water into, or groundwater out of, the groundwater-flow system beneath the Barnegat Bay-Little Egg Harbor and portions of the Atlantic Ocean and Great Bay is determined by using budget analysis of flow to constant head cells that represent this area. Results of simulations of 2000-03 and maximumallocation conditions are used to examine the effects of groundwater withdrawals on the flow of groundwater to coastal saltwater boundaries.

Constant head cells represent all or portions of the Atlantic Ocean, Barnegat Bay-Little Egg Harbor, Great Bay, and low-lying coastal and bay swamps and wetlands in the groundwater-flow model. For 2000-03 groundwater withdrawals, a large number of constant head cells have net flow away from the cell (area is shown in blue in fig. 33A). Flow is out of constant head cells to adjacent variable head cells beneath layer 1, indicating predominantly downward flow. A large part of the Barnegat Bay-Little Egg Harbor and coastal wetlands have a net flux out of the constant head cells, particularly in the southern half of the Ocean County study area. The area of downward flow encompasses most of the Atlantic Ocean, as represented in the flow model; except for cells immediately adjacent to the barrier island in the northern half of the study area and an area adjacent to the northeastern boundary (area is shown in green in fig. 33A). Although water flows away from most cells, the total flux into all constant head cells is $113.7 \mathrm{ft}^{3} / \mathrm{s}$. Flow values indicate that downward flow out of individual constant head cells tends to be very small; lateral or upward flow into constant head cells is larger than the flow out of the cells.

Maximum-allocation groundwater withdrawals affect the quantity of groundwater discharging directly into Barnegat Bay. In this simulation, the number of constant head cells with flows into the cells and their total area in the Barnegat Bay-Little Egg Harbor estuary are considerably less than 2000-03 conditions. Groundwater discharging to the estuary is restricted to a small area south of the mouth of Toms River with additional cells adjacent to the barrier island (fig. 33B). The total flux into all of the constant head cells in this simulation decreased by 5.1 to $108.6 \mathrm{ft}^{3} / \mathrm{s}$. The reduction in flow to constant head cells is attributed to additional groundwater withdrawals in this simulation. 

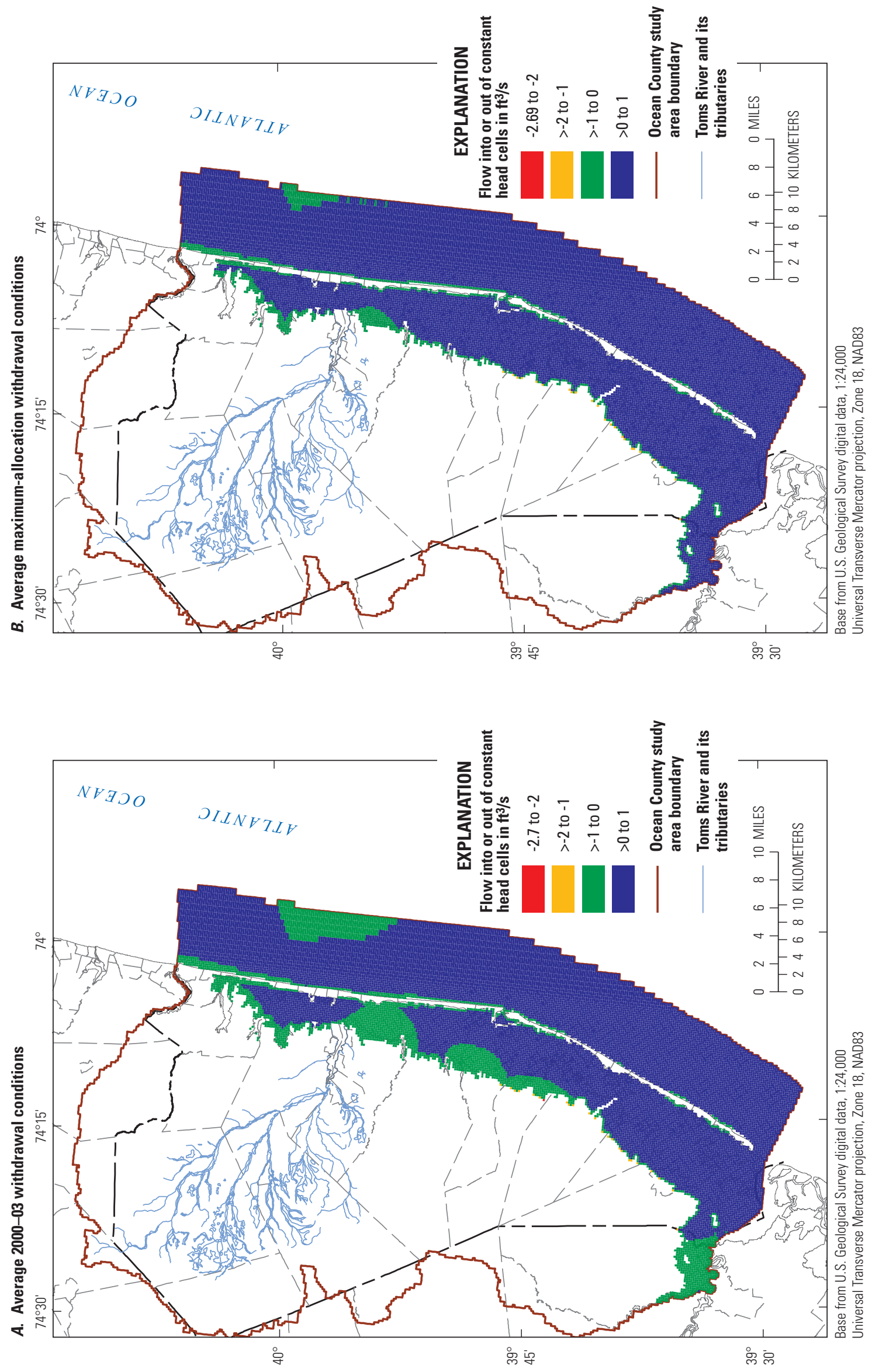

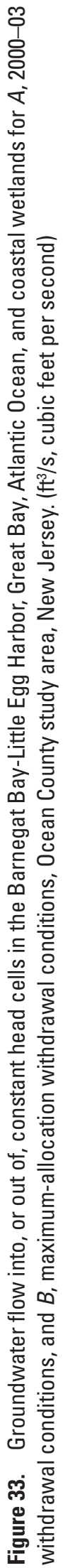




\section{Conclusions}

Results of the simulations of 2000-03 and maximumallocation groundwater withdrawals on groundwater flow in the aquifers of Ocean County and vicinity indicate the following conclusions.

- Compared with simulated no-withdrawal conditions, 2000-03 withdrawals reduced groundwater flow out of the Kirkwood-Cohansey aquifer system into streams by less than 9 percent at streamflow-gaging stations.

- Compared with simulated no-withdrawal conditions, net flow out of the Kirkwood-Cohansey aquifer system to adjacent layers increased under 2000-03 withdrawal conditions.

- When compared with no-withdrawal conditions, maximum-allocation withdrawals reduced the total simulated base flow to the Barnegat Bay-Little Egg Harbor estuary by 10 to 20 percent, depending on selected recharge rates.

- Maximum-allocation withdrawal water levels decreased substantially from simulated no-withdrawal water levels in the Rio Grande water-bearing zone, with a cone of depression deepening during a summer stress period (August 2002 recharge; stress period 73).

- A cone of depression in the Atlantic City 800-foot sand expanded further inland during the same summer stress period (August 2002 recharge) and deepened under maximum-allocation withdrawal conditions.

- The simulated maximum-allocation withdrawal potentiometric surfaces of the Piney Point aquifer during summer stress periods indicated the expansion of several cones of depression that had developed during 2000-03 withdrawal conditions.

- Most near-shore wells screened in the KirkwoodCohansey aquifer system derived water from updip sources inland, although wells located in Seaside Heights Borough had some flow paths that originated beneath Barnegat Bay or the Atlantic Ocean.

- Travel times to those near-shore wells with flow paths originating beneath Barnegat Bay or the Atlantic Ocean ranged from slightly less than 350 years to as much as 10,400 years under average yearly 2000-03 withdrawal conditions, indicating susceptibility to saltwater intrusion only in the relatively distant future.

- Under average yearly 2000-03 withdrawal conditions, flow paths from recharge areas to wells screened in the Rio Grande water-bearing zone and Atlantic City 800foot sand had travel times that ranged from nearly 530 to approximately 3.73 million years, with most wells deriving a large part of their recharge from the inland Oswego River Basin.

- Travel times along flow paths originating beneath the Barnegat Bay-Little Egg Harbor or offshore of the southern part of Long Beach island to wells screened in the Rio Grande water-bearing zone and Atlantic City 800 -foot sand were estimated to be between nearly 19,000 and 517,000 years under average yearly 2000-03 withdrawal conditions, indicating that the water quality in these wells is not likely to be affected by saltwater intrusion in the foreseeable future.

- Travel times from recharge to discharge point for wells screened in the Kirkwood-Cohansey aquifer system in Seaside Heights Borough and Island Beach State Park, with flow paths that originated beneath the Barnegat Bay or the Atlantic Ocean, were approximately 400 to 12,000 years under average yearly maximum-allocation withdrawal conditions. However, a well in Ship Bottom Borough is potentially susceptible to saltwater intrusion along flow paths with travel times of approximately 140 to 7,400 years.

- Under average yearly maximum-allocation withdrawal conditions, wells located on the mainland had flow paths that originated farther inland and were not susceptible to saltwater intrusion. Travel times of water entering all Rio Grande water-bearing zone and Atlantic City 800-foot sand wells ranged from approximately 400 to 268,000 years.

- In maximum-allocation withdrawal simulations, groundwater flow into Barnegat Bay is considerably less, and from a more restricted area, than in average 2000-03 withdrawal simulations, indicating that maximum-allocation withdrawal conditions have a more profound effect on flow to the Bay than do 2000-03 withdrawal conditions.

\section{Summary}

Rapid population growth and land development in Ocean County, New Jersey, between 1930 and 2000 led to a conversion of undeveloped/barren, forested, and agricultural land to urban land. Large withdrawals of surface water and groundwater to supply the needs of the population affected the freshwater supply in a number of ways, including reduced streamflow, base flow, and total flow of freshwater into the Barnegat Bay-Little Egg Harbor estuary. Freshwater discharging to the Barnegat Bay-Little Egg Harbor estuary from both streams and direct groundwater flow is essential to maintaining the ecology of the bay. The U.S. Geological Survey, in cooperation with the New Jersey Department of Environmental Protection (NJDEP), developed a three-dimensional 
groundwater-flow model of the unconfined and confined aquifers in the Ocean County area to determine the effects of 2000-03 and maximum-allocation groundwater withdrawals on groundwater flow. The model also is used to evaluate the quantity of freshwater discharging into the Barnegat BayLittle Egg Harbor estuary.

The model included the surficial, unconfined KirkwoodCohansey aquifer system, and the underlying, confined Rio Grande water-bearing zone, Atlantic City 800 -foot sand, Piney Point aquifer, and Vincentown aquifer in order to represent the regional groundwater-flow system. The groundwaterflow model simulated year 2000 average conditions as initial conditions, followed by monthly stress periods representing January 2000 through December 2003 conditions. Simulated base flow, water budgets, and groundwater levels during five selected stress periods $(64,73,77,80$, and 87$)$ that simulate monthly hydrologic conditions representative of November 2001, August and December 2002, and March and October 2003 were used to compare and contrast three withdrawal schemes. These were (1) no-withdrawal conditions, (2) 2000-03 withdrawal conditions that used monthly withdrawals from production wells from 2000 through 2003, and (3) maximum-allocation withdrawal conditions using the maximum withdrawals at each well permitted by NJDEP.

During no-withdrawal conditions, the largest and most variable component of water entering the groundwater-flow system is recharge ( 0 to $2,290 \mathrm{ft}^{3} / \mathrm{s}$ ), followed by net flow into storage ( 27 to $\left.602 \mathrm{ft}^{3} / \mathrm{s}\right)$. The largest component of groundwater flow out of the Kirkwood-Cohansey aquifer system entered streams, with net flow ranging from 484 to $1,086 \mathrm{ft}^{3} / \mathrm{s}$. Groundwater flow out to streams, which subsequently discharged into the Barnegat Bay-Little Egg Harbor estuary, ranged from 326 to $759 \mathrm{ft}^{3} / \mathrm{s}$ per stress period.

In general, water in the Kirkwood-Cohansey aquifer system entered storage during high recharge conditions, flowed out to constant head cells, and also flowed out to adjacent layers in the model. But, in comparison with simulated no-withdrawal conditions, 2000-03 withdrawals reduced groundwater flow out of the Kirkwood-Cohansey aquifer system to constant head cells ( 5 to 8 percent) as well as flow into streams ( 6 to 10 percent), whereas simulated net flow out of the KirkwoodCohansey aquifer system to adjacent layers increased (27 to 55 percent) compared with no-withdrawal conditions.

The percent reduction in base flow from no-withdrawal to $2000-03$ withdrawal conditions is moderate-less than 9 percent at all streamflow-gaging stations. However, during stress period 64 (November 2001 recharge), base flow from all streams that flow into the Barnegat Bay-Little Egg Harbor estuary is less than half of base flow simulated for stress period 77 (December 2002 recharge) because of a much lower recharge rate and larger withdrawals, resulting in reductions in base flow to the Barnegat Bay-Little Egg Harbor estuary of 12 percent and 6.4 percent, respectively).

For the confined aquifers, simulations indicated that 2000-03 withdrawals created regional cones of depression in their potentiometric surfaces. The simulated potentiometric surface of the Rio Grande water-bearing zone declined at the southern end of Long Beach Island to an altitude of -10 to -20 feet during stress period 80 and to -40 to -60 feet during stress period 73 (March 2003 and August 2002 recharge, respectively), with larger seasonal water-level fluctuations close to the center of the cone of depression than elsewhere. Simulated seasonal variations in water levels in the Atlantic City 800-foot sand, upper and lower sands, varied as much as 20 to 30 feet and regional water levels ranged from -20 feet during stress period 80 to -40 feet during stress period 73 . Simulated water levels in the Piney Point aquifer during stress period 80 were at an altitude of -20 feet in southern Long Beach Township, Barnegat Light and Seaside Park Boroughs, and the mainland communities of Berkeley Township, Ocean Gate Borough, and Toms River Township. The cones of depression expanded and deepened during stress period 73, particularly in Barnegat Light Borough and the bay side of Toms River Township, Berkeley Township, and the barrier island community of Seaside Park Borough north to Lavallette Borough.

Under maximum-allocation withdrawal conditions, groundwater withdrawals from the Kirkwood-Cohansey aquifer system indicated net flow to constant head cells is slightly less than that during 2000-03 withdrawals. Under the maximum-allocation scenario, the net flow out to the lower confined aquifers is greater than that shown during $2000-03$ withdrawals, and simulated net flow out to streams is less than 2000-03 flows. When compared with no-withdrawal conditions, maximum-allocation withdrawals reduced the total simulated base flow to the Barnegat Bay-Little Egg Harbor estuary by 10 to 20 percent, using December 2002 and November 2001 recharge, respectively (stress periods 77 and 64).

Maximum-allocation withdrawal water levels decreased substantially from simulated no-withdrawal water levels in the Rio Grande water-bearing zone. The cone of depression in the Rio Grande water-bearing zone potentiometric surface, centered at Holgate, deepened during a summer stress period (August 2002 recharge). Similarly, a cone of depression in the Atlantic City 800-foot sand expanded further inland during the same stress period and deepened to - 100 feet at Surf City Borough south to Beach Haven Township. The simulated maximum-allocation withdrawal potentiometric surfaces of the Piney Point aquifer during spring and summer stress periods (March 2003 and August 2002) indicated the expansion of several cones of depression that had developed during 2000-03 withdrawal conditions.

Particle tracking routines estimated groundwater-flow paths and travel times through, and location of recharge to, the groundwater-flow system. The vulnerability of wells to saltwater intrusion is assessed by tracking particles of water from the screen interval of production wells in the Kirkwood-Cohansey aquifer system, Rio Grande water-bearing zone, or Atlantic City 800 -foot sand backward to the point where particles entered the simulated aquifer system. 
Simulation of average yearly $2000-03$ withdrawal conditions indicated the travel time of most flow paths to KirkwoodCohansey aquifer system wells ranged from 11 years to nearly 50,700 years. While most near-shore wells screened in the Kirkwood-Cohansey aquifer system derived water from updip sources inland, wells located in Seaside Heights Borough, had some flow paths that originated beneath Barnegat Bay or the Atlantic Ocean and were susceptible to saltwater intrusion. Travel times to these wells range from slightly less than 350 years to as much as 10,400 years. Most wells screened in the Rio Grande water-bearing zone and Atlantic City 800foot sand derived a large amount of their recharge from the Oswego River Basin area, and flow paths had travel times that ranged from nearly 530 to greater than 3.73 million years. Travel time of the flow paths that originated beneath the Barnegat Bay-Little Egg Harbor or offshore of the southern part of Long Beach island were estimated to be between nearly 19,000 and 517,000 years, indicating that the water quality in these wells is not likely to be affected by saltwater intrusion in the foreseeable future.

Simulation of average yearly maximum-allocation withdrawal conditions indicated that wells screened in the Kirkwood-Cohansey aquifer system in Seaside Heights Borough and in Island Beach State Park, Berkeley Township, had flow paths that started beneath the Barnegat Bay or the Atlantic Ocean; with travel times from recharge to discharge point approximately 400 to 12,000 years, they are unlikely to be affected by saltwater intrusion in the near future. However, a well in Ship Bottom Borough is potentially susceptible to saltwater intrusion along flow paths with travel times of approximately 140 to 7,400 years. Wells on the mainland had flow paths that originated farther inland and were not susceptible to saltwater intrusion.

For maximum-allocation withdrawal conditions, travel times of water entering all Rio Grande water-bearing zone and Atlantic City 800-foot sand wells ranged from approximately 400 to 268,000 years. Wells in the boroughs of Harvey Cedars, Surf City, Ship Bottom, and Beach Haven, and in Long Beach Township, had flow paths that originated in a combination of areas beneath the Barnegat Bay-Little Egg Harbor or the Atlantic Ocean and on the mainland. Travel times of particles that started beneath either the Barnegat Bay-Little Egg Harbor or the Atlantic Ocean ranged from approximately 2,300 to more than 134,000 years.

Average yearly 2000-03 and maximum-allocation withdrawal simulations provided a comparison of the net flux of groundwater discharging from the groundwater-flow system into the Barnegat Bay-Little Egg Harbor estuary. In the average maximum-allocation withdrawal simulation, the total area of constant head cells with flow into the cell in the estuary is considerably less than average 2000-03 withdrawal conditions. Groundwater discharging to the estuary is restricted primarily to a small area south of the mouth of Toms River with additional cells adjacent to the barrier island, with a decrease of $5.1 \mathrm{ft}^{3} / \mathrm{s}$ in net flux into all constant head cells.

\section{References Cited}

Anderson, H.R., and Appel, C.A., 1969, Geology and groundwater resources of Ocean County, New Jersey: New Jersey Department of Conservation and Economic Development Special Report 29, 93 p.

Anderson, M.P., and Woessner, W.W., 1991, Applied groundwater modeling - Simulation of flow and advective transport: San Diego, Calif., Academic Press, Inc., 381 p.

Baehr, A.L., Kauffman, L.J., Perkins, Kimberlie, and Nolan, B.T., 2003, Estimating spatial variability of recharge in southern New Jersey from unsaturated-zone measurements: U.S. Geological Survey Water-Resources Investigations Report 02-4288, $31 \mathrm{p}$.

Belcher, W.R., ed., 2004, Death Valley regional groundwater flow system, Nevada and California-Hydrogeologic framework and transient ground-water flow model: U.S. Geological Survey Scientific Investigations Report 2004-5205, 408 p.

Brown, G.A., and Zapecza, O.S., 1990, Results of test drilling in Howell township, Monmouth county, New Jersey: U.S. Geological Survey Water-Resources Investigations Report 90-4062, $42 \mathrm{p}$.

Charles, E.G., Behroozi, Cyrus, Schooley, Jack, and Hoffman, J.L., 1993, A method for evaluating ground-water-recharge areas in New Jersey: New Jersey Geological Survey Report GSR-32, 95 p., accessed on January 3, 2009, at http://www. state.nj.us/dep/njgs/pricelst/gsreport/gsr32.pdf.

dePaul, V.T., Rosman, Robert, and Lacombe, P.J., 2009, Water-level conditions in selected confined aquifers of the New Jersey and Delaware coastal plain, 2003: U.S. Geological Survey Scientific Investigations Report 2008-5145, 123 p., 9 pls.

Fegeas, R.G., Claire, R.W., Guptill, S.C., Anderson, E.K., and Hallam, C.A., 1983, Land use and land cover digital data: U.S. Geological Survey Circular 895-E, 21 p.

Freeze, R.A., and Cherry, J.A., 1979, Groundwater: Englewood Cliffs, N.J., Prentice-Hall, Inc., 604 p.

Gill, H.E., 1962, Ground-water resources of Cape May County, New Jersey-Salt-water invasion of principal aquifers: New Jersey Department of Conservation and Economic Development Special Report 18, 171 p.

Gordon, A.D., 2004, Hydrology of the unconfined KirkwoodCohansey aquifer system, Forked River and Cedar, Oyster, Mill, Westecunk, and Tuckerton Creek Basins and adjacent basins in the southern Ocean County area, New Jersey, 1998-99: U.S. Geological Survey Water-Resources Investigations Report 03-4337, 5 pls. 
Harbaugh, A.W., 2005, MODFLOW-2005, The U.S. Geological Survey modular ground-water model - the GroundWater Flow Process: U.S. Geological Survey Techniques and Methods 6-A16 [variously paged].

Harbaugh, A.W., and Tilley, C.L., 1984, Steady-state computer model of the water-table aquifer in the Mullica River basin, the Pine Barrens, New Jersey: U.S. Geological Survey Water-Resources Investigations Report 84-4295, 38 p.

Hill, M.C., and Tiedeman, C.R., 2007, Effective groundwater model calibration, with analysis of data, sensitivities, predictions and uncertainty: New York, John Wiley and Sons, $455 \mathrm{p}$.

Isphording, W.C., 1970, Petrology, stratigraphy, and re-definition of the Kirkwood formation (Miocene) of New Jersey: Journal of Sedimentary Petrology, v. 40, no. 3, p. 986-997.

Johnson, M.L., and Watt, M.K., 1996, Hydrology of the unconfined aquifer system, Mullica River basin, New Jersey, 1991-92: U.S. Geological Survey Water-Resources Investigations Report 94-4234, 6 sheets.

Kauffman, L.J., Baehr, A.L., Ayers, M.A., and Stackelberg, P.E., 2001, Effects of land use and travel time on the distribution of nitrate in the Kirkwood-Cohansey aquifer system in southern New Jersey: U.S. Geological Survey WaterResources Investigations Report 01-4117, 58 p.

Lacombe, P.J., and Rosman, Robert, 1997, Water levels in, extent of freshwater in, and water withdrawal from eight major confined aquifers, New Jersey coastal plain, 1993: U.S. Geological Survey Water-Resources Investigations Report 96-4206, 8 sheets.

Lacombe, P.J., and Rosman, Robert, 2001, Water levels in, extent of freshwater in, and water withdrawals from ten confined aquifers, New Jersey and Delaware coastal plain, 1998: U.S. Geological Survey Water-Resources Investigations Report 00-4143, 10 sheets.

Leake, S.A., and Lilly, M.R., 1997, Documentation of a computer program (FHB1) for assignment of transient specified-flow and specified-head boundaries in applications of the modular finite-difference ground-water flow model (MODFLOW): U.S. Geological Survey Open-File Report 97-571, $56 \mathrm{p}$.

Martin, Mary, 1998, Ground-water flow in the New Jersey Coastal Plain: U.S. Geological Survey Professional Paper 1404-H, $146 \mathrm{p}$.

McAuley, S.D., Barringer, J.L., Paulachok, G.N., Clark, J.S., and Zapecza, O.S., 2001, Ground-water flow and quality in the Atlantic City 800-foot sand, New Jersey: New Jersey Department of Environmental Protection Geological Survey Report GSR 41, 86 p., accessed October 14, 2010, at http:// www.state.nj.us/dep/njgs/pricelst/gsreport/gsr41.pdf.
Nemickas, Bronius, and Carswell, L.D., 1976, Stratigraphic and hydrologic relationship of the Piney Point aquifer and the Alloway clay member of the Kirkwood formation in New Jersey: U.S. Geological Survey Journal of Research, v. 4 , no. 1, p. 1-7.

New Jersey Department of Environmental Protection, Office of Information Resources Management, Bureau of Geographic Information Systems, 2010, NJDEP 2007 Land Use/ Land Cover Update (7/19/10), accessed October 22, 2014, at http://www.nj.gov/dep/gis/lulc07cshp.html.

New Jersey Geological and Water Survey, 2005, DGS02-3 ground-water recharge for New Jersey: New Jersey Geological and Water Survey digital geodata series, accessed October 14, 2010, at http://www.state.nj.us/dep/njgs/geodata/dgs02-3.htm.

Newell, W.L., Powars, D.S., Owens, J.P., Stanford, S.D., and Stone, B.D., 2000, Surficial geologic map of central and southern New Jersey: U.S. Geological Survey Miscellaneous Investigations Series Map I-2450-D, 21 p., 3 sheets.

Nicholson, R.S., and Watt, M.K., 1997, Simulation of groundwater flow in the unconfined aquifer system of the Toms River, Metedeconk River, and Kettle Creek basins, New Jersey: U.S. Geological Survey Water-Resources Investigations Report 97-4066, 100 p.

Ocean County Department of Planning, 2006, Ocean County data book: Ocean County Department of Planning, accessed May 10, 2006, at http://www.planning.co.ocean.nj.us/databooktoc.htm.

Ocean County Department of Planning, 2009, Historical population trends in Ocean County, by municipality, 1930-2000: Ocean County Department of Planning, accessed October 22, 2014, at http://www.planning.co.ocean.nj.us/databook/02_OC_Pop30.pdf.

Owens, J.P., Sugarman, P.J., Sohl, N.F., Parker, R.A., Houghton, H.F., Volkert, R.A., Drake, A.A., Jr., and Orndorff, R.C., 1998, Bedrock geologic map of central and southern New Jersey: U.S. Geological Survey Miscellaneous Investigations Series Map I-2540-B, 4 sheets.

Poeter, E.P., Hill, M.C., Banta, E.R., Mehl, Steffen, and Christensen, Steen, 2005, UCODE_2005 and six other computer codes for universal sensitivity analysis, calibration, and uncertainty evaluation constructed using the Jupiter API: U.S. Geological Survey Techniques and Methods, book 6, chap. A11, 283 p.

Pollock, D.W., 2012, User guide for MODPATH version 6-A particle-tracking model for MODFLOW: U.S. Geological Survey Techniques and Methods, book 6, chap. A41, 58 p. 
Pope, D.A., Carleton, G.B., Buxton, D.E., Walker, R.L., Shourds, J.L., and Reilly, P.A., 2012, Simulated effects of alternative withdrawal strategies on groundwater flow in the unconfined Kirkwood-Cohansey aquifer system, the Rio Grande water-bearing zone, and the Atlantic City 800 -foot sand in the Great Egg Harbor and Mullica River Basins, New Jersey: U.S. Geological Survey Scientific Investigations Report 2012-5187, 139 p.

Reilly, T.E., and Harbaugh, A.W., 2004, Guidelines for evaluating ground-water flow models: U.S. Geological Survey Scientific Investigations Report 2004-5038, 37 p.

Rhodehamal, E.C., 1973, Geology and water resources of the Wharton tract and the Mullica River basin in southern New Jersey: New Jersey Department of Environmental Protection Special Report 36, 58 p.

Rosman, Robert, Lacombe, P.J., and Storck, D.A., 1995, Water levels in major artesian aquifers of the New Jersey coastal plain, 1988: U.S. Geological Survey Water-Resources Investigations Report 95-4060, 74 p., 8 pls.

Rush, F.E., 1968, Geology and ground-water resources of Burlington County, New Jersey: New Jersey Department of Conservation and Economic Development Special Report $26,45 \mathrm{p}$.

Rutledge, A.T., 1993, Computer programs for describing the recession of ground-water discharge and for estimating mean ground-water recharge and discharge from streamflow records: U.S. Geological Survey Water-Resources Investigations Report 93-4121, 45 p.

Sugarman, P.J., 2001, Hydrostratigraphy of the Kirkwood and Cohansey formations of Miocene age in Atlantic County and vicinity, New Jersey: New Jersey Geological Survey Report 40, 26 p., accessed October14, 2010, at http://www. state.nj.us/dep/njgs/pricelst/gsreport/gsr40.pdf.
U.S. Census Bureau, 2009, Table 1-Annual estimates of the residential population for counties of New Jersey-April 1, 2000 to July 1, 2008: U.S. Census Bureau CO-EST200801-34, accessed July 17, 2009, at http://www.census.gov/ popest/data/counties/totals/2008/tables/CO-EST2008-01-34. xls.

Voronin, L.M., 2004, Documentation of revisions to the regional aquifer system analysis model of the New Jersey coastal plain: U.S. Geological Survey Water-Resources Investigations Report 03-4268, 49 p., and CD-ROM.

Voronin, L.M., Spitz, F.J., and McAuley, S.D., 1996, Evaluation of saltwater intrusion and travel time in the Atlantic City 800-foot sand, Cape May County, New Jersey, 1992, by use of a coupled-model approach and flow-path analysis: U.S. Geological Survey Water-Resources Investigations Report 95-4280, 27 p.

Watt, M.K., Johnson, M.L., and Lacombe, P.J., 1994, Hydrology of the unconfined aquifer system, Toms River, Metedeconk River, and Kettle Creek basins, New Jersey, 1987-90: U.S. Geological Survey Water-Resources Investigations Report 93-4110, 5 pls.

Watt, M.K., Kane, A.C., Charles, E.G., and Storck, D.A., 2002, Hydrology of the unconfined aquifer system, Rancocas Creek area, Rancocas, Crosswicks, Assunpink, Blacks, and Crafts Creek Basins, New Jersey, 1996: U.S. Geological Survey Water-Resources Investigations Report 2002-4280, 5 pls.

Zapecza, O.S., 1989, Hydrogeologic framework of the New Jersey coastal plain, regional aquifer-system analysisNorthern Atlantic coastal plain: U.S. Geological Survey Professional Paper 1404-B, 49 p.

Zapecza, O.S., Voronin, L.M., and Martin, Mary, 1987, Ground-water-withdrawal and water-level data used to simulate regional flow in the major coastal plain aquifers of New Jersey: U.S. Geological Survey Water-Resources Investigations Report 87-4038, 120 p. 
Table 10. Calibrated model parameter values and composite scaled sensitivities, Ocean County study area, New Jersey.

[Location of Ocean County study area is shown in figure 1; $\mathrm{ft} / \mathrm{d}$, feet per day; --, less than 1.0]

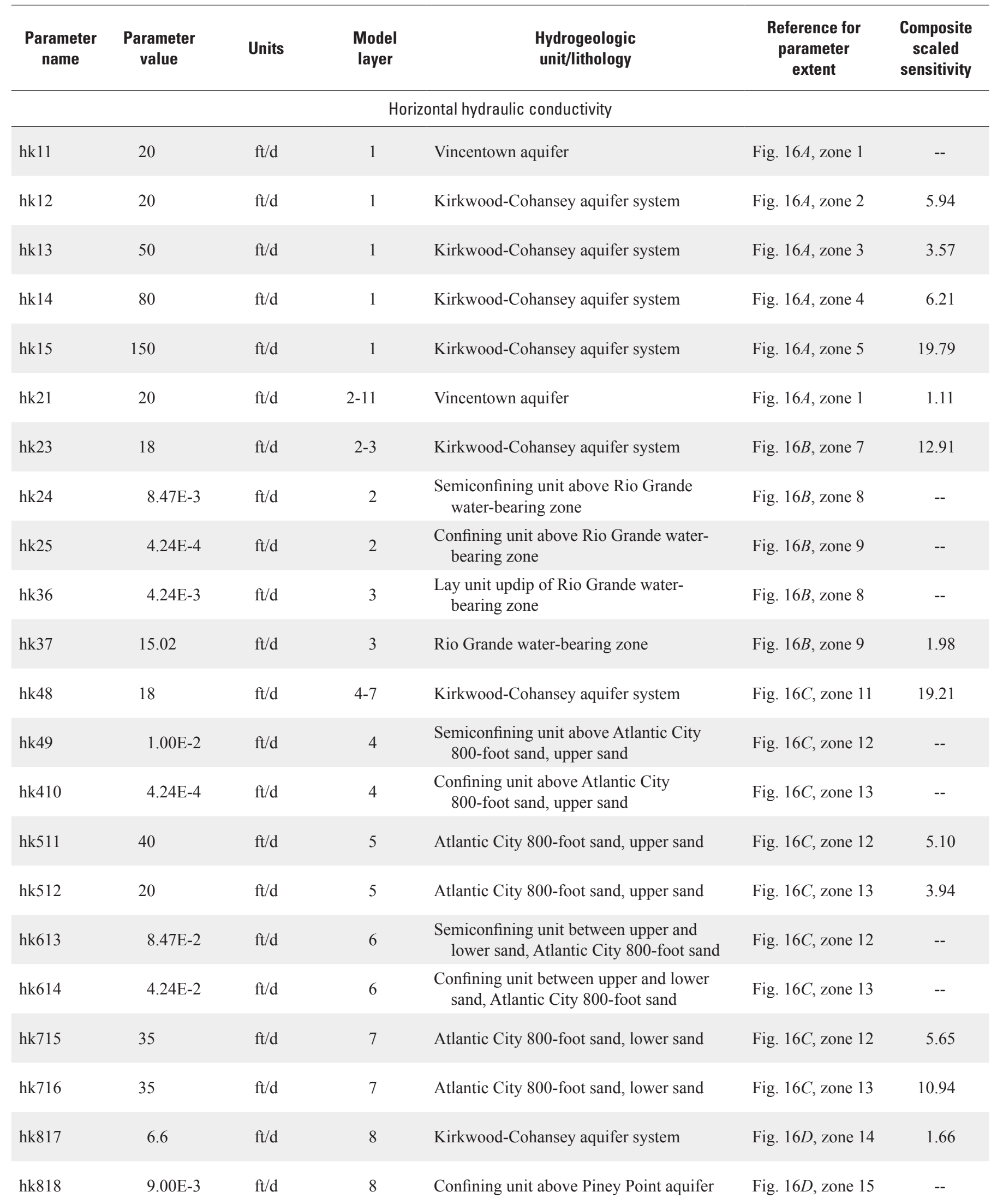


Table 10. Calibrated model parameter values and composite scaled sensitivities, 0cean County study area, New Jersey.-Continued [Location of Ocean County study area is shown in figure 1; ft/d, feet per day; --, less than 1.0]

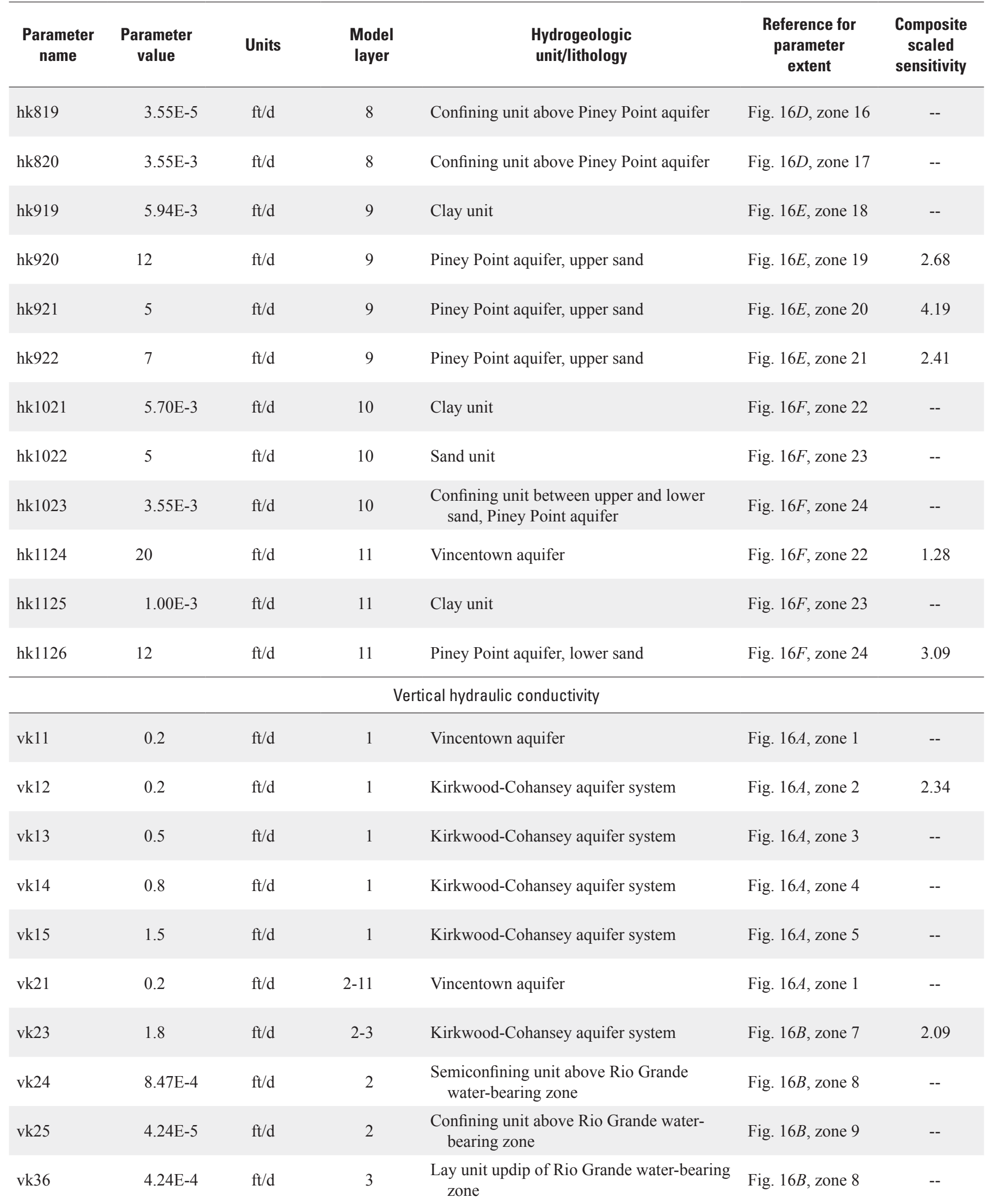


Table 10. Calibrated model parameter values and composite scaled sensitivities, Ocean County study area, New Jersey.-Continued

[Location of Ocean County study area is shown in figure 1; ft/d, feet per day; --, less than 1.0]

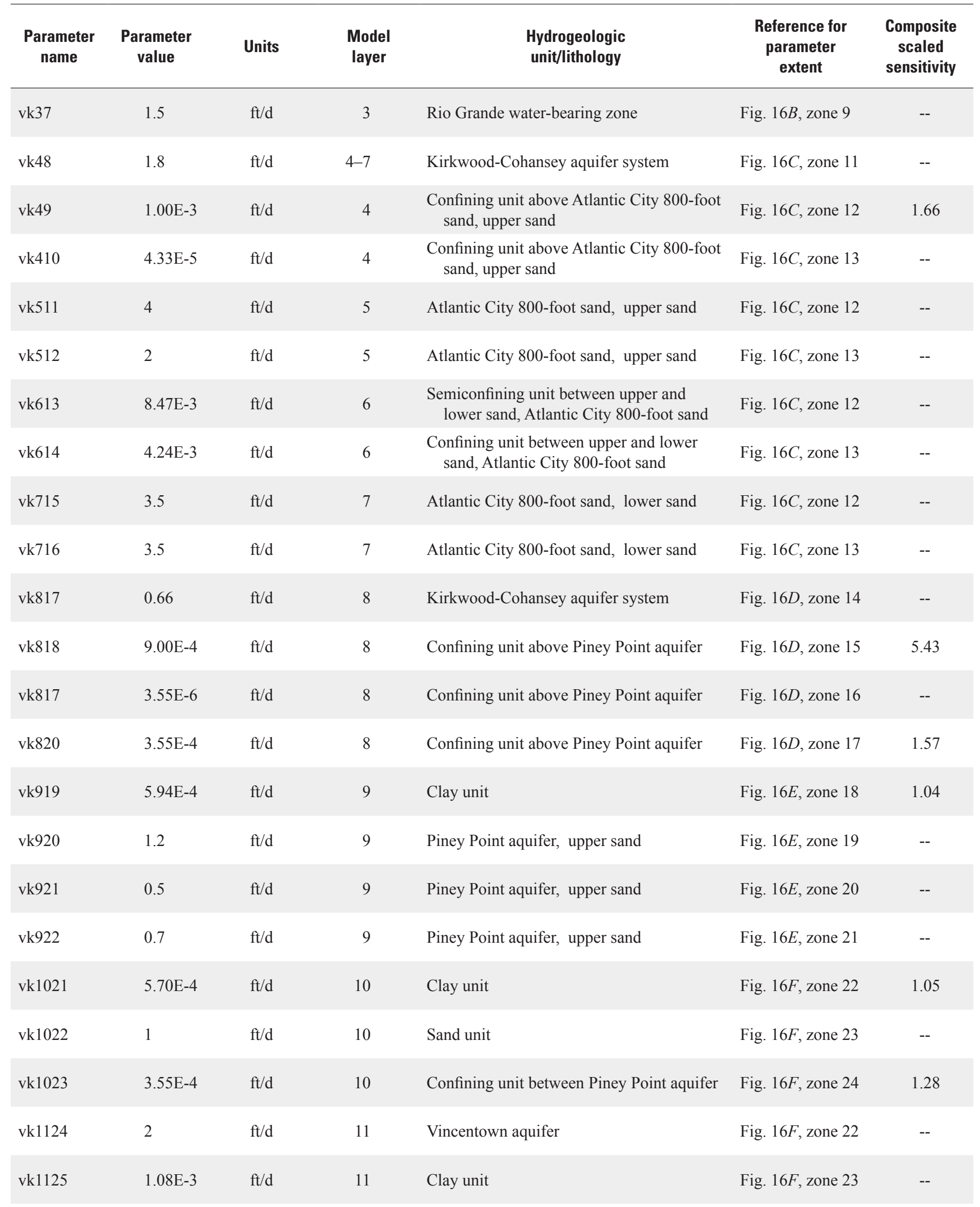


Table 10. Calibrated model parameter values and composite scaled sensitivities, 0cean County study area, New Jersey.-Continued [Location of Ocean County study area is shown in figure 1; ft/d, feet per day; --, less than 1.0]

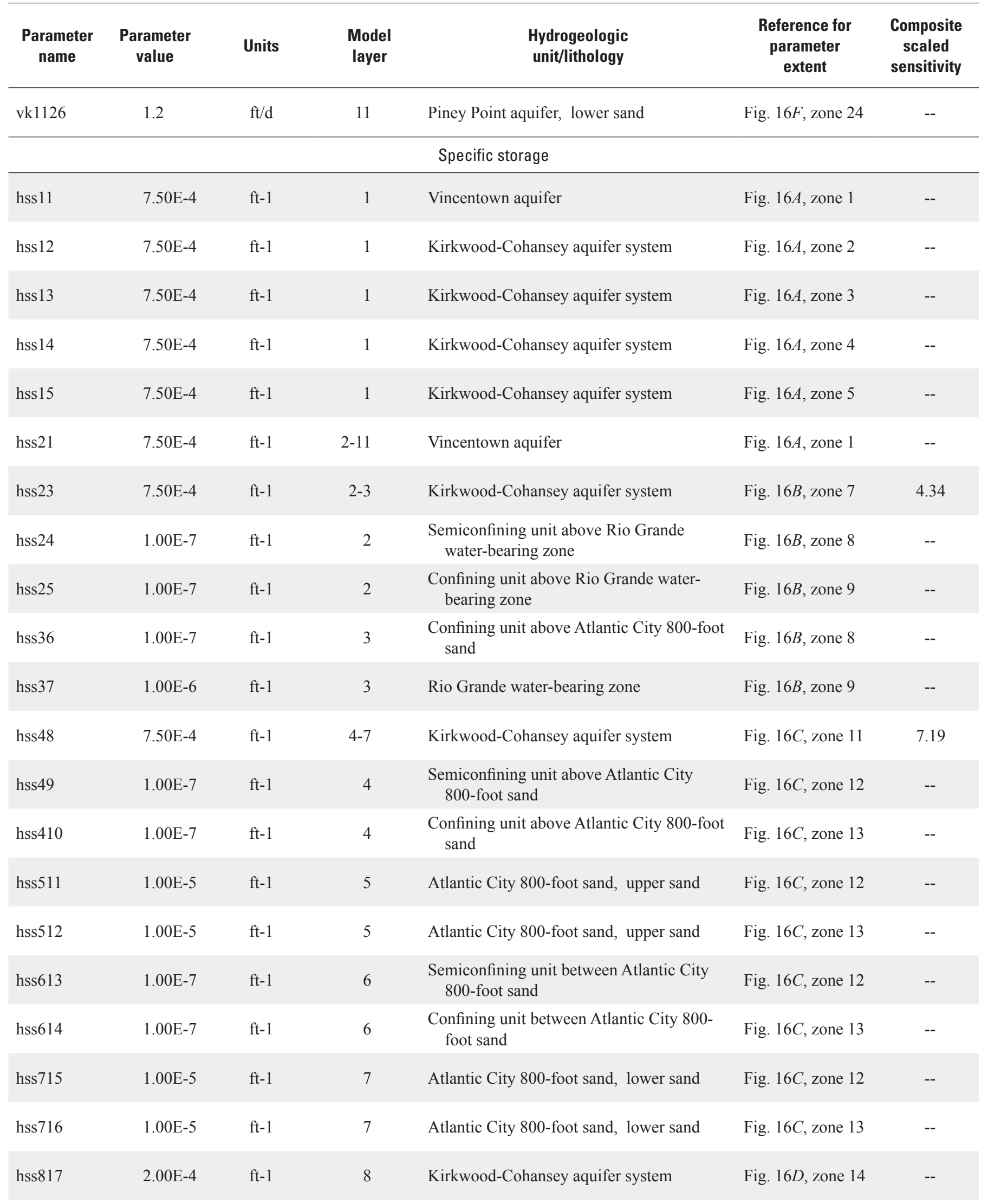


Table 10. Calibrated model parameter values and composite scaled sensitivities, Ocean County study area, New Jersey.-Continued [Location of Ocean County study area is shown in figure 1; ft/d, feet per day; --, less than 1.0]

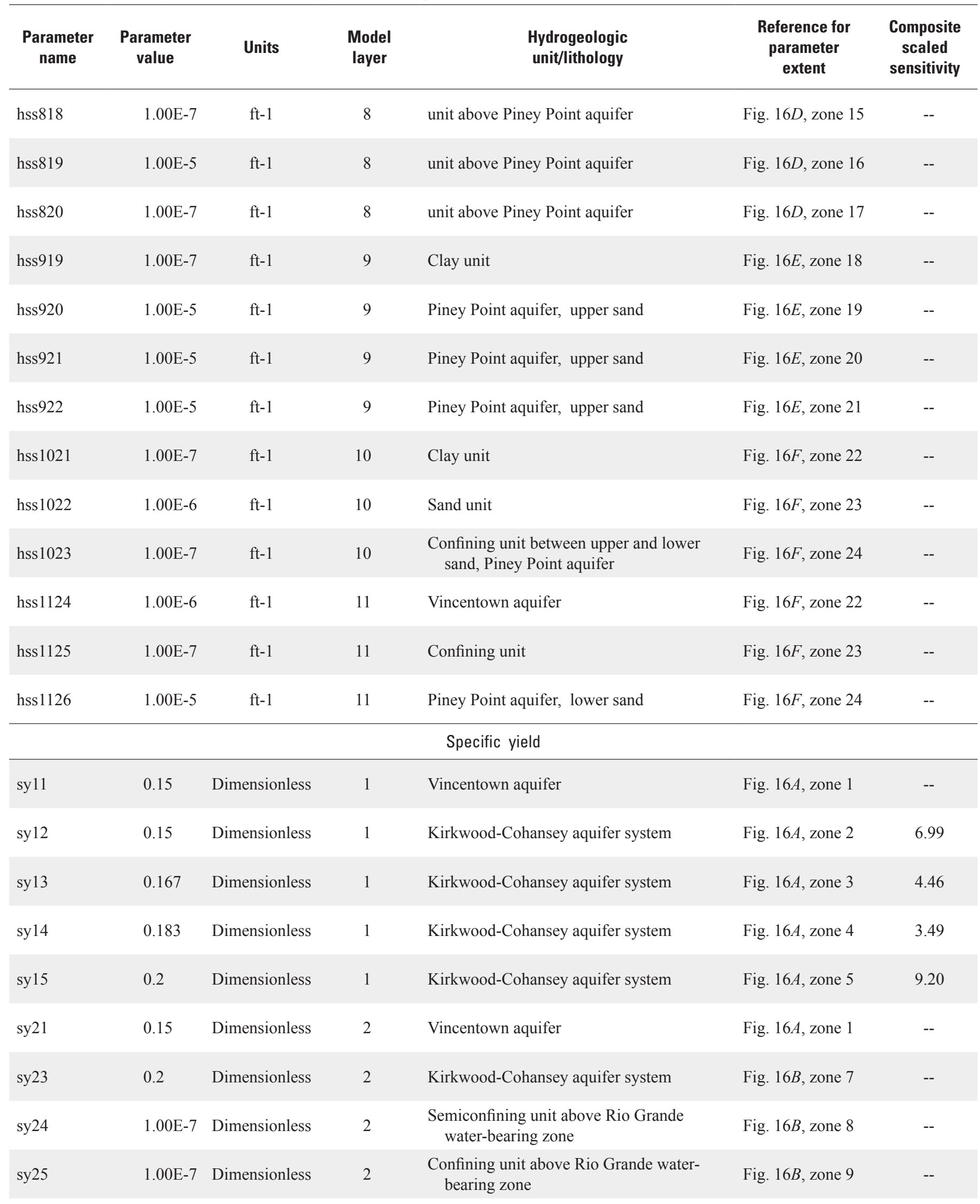


Table 10. Calibrated model parameter values and composite scaled sensitivities, Ocean County study area, New Jersey.-Continued [Location of Ocean County study area is shown in figure 1; $\mathrm{ft} / \mathrm{d}$, feet per day; --, less than 1.0]

\begin{tabular}{|c|c|c|c|c|c|c|}
\hline $\begin{array}{c}\text { Parameter } \\
\text { name }\end{array}$ & $\begin{array}{c}\text { Parameter } \\
\text { value }\end{array}$ & Units & $\begin{array}{l}\text { Model } \\
\text { layer }\end{array}$ & $\begin{array}{c}\text { Hydrogeologic } \\
\text { unit/lithology }\end{array}$ & $\begin{array}{l}\text { Reference for } \\
\text { parameter } \\
\text { extent }\end{array}$ & $\begin{array}{c}\text { Composite } \\
\text { scaled } \\
\text { sensitivity }\end{array}$ \\
\hline \multicolumn{7}{|c|}{ Streambed hydraulic conductivity } \\
\hline drainK & 0.25 & $\mathrm{ft} / \mathrm{d}$ & NA & NA & NA & 38.17 \\
\hline riverbedK & 0.35 & $\mathrm{ft} / \mathrm{d}$ & NA & NA & NA & 77.23 \\
\hline \multicolumn{7}{|c|}{ Recharge } \\
\hline rech_north & 1.8 & $\begin{array}{l}\text { multiplier, } \\
\text { dimensionless }\end{array}$ & NA & NA & NA & 267.48 \\
\hline rech_south & 1.8 & $\begin{array}{c}\text { multiplier, } \\
\text { dimensionless }\end{array}$ & NA & NA & NA & 109.54 \\
\hline
\end{tabular}


Publishing support provided by the U.S. Geological Survey Science Publishing Network, West Trenton Publishing Service Center

For more information concerning the research in this report, contact: Director, New Jersey Water Science Center

U.S. Geological Survey

3450 Princeton Pike, Suite 110

Lawrenceville, NJ 08648

http://nj.usgs.gov 


\section{$\frac{\mathbb{2}}{\mathrm{C}}$}

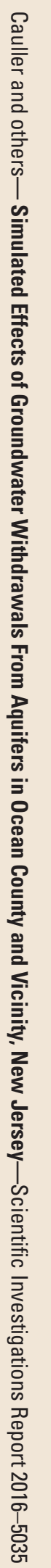

ISSN 2328-0328 (online) 